Orin
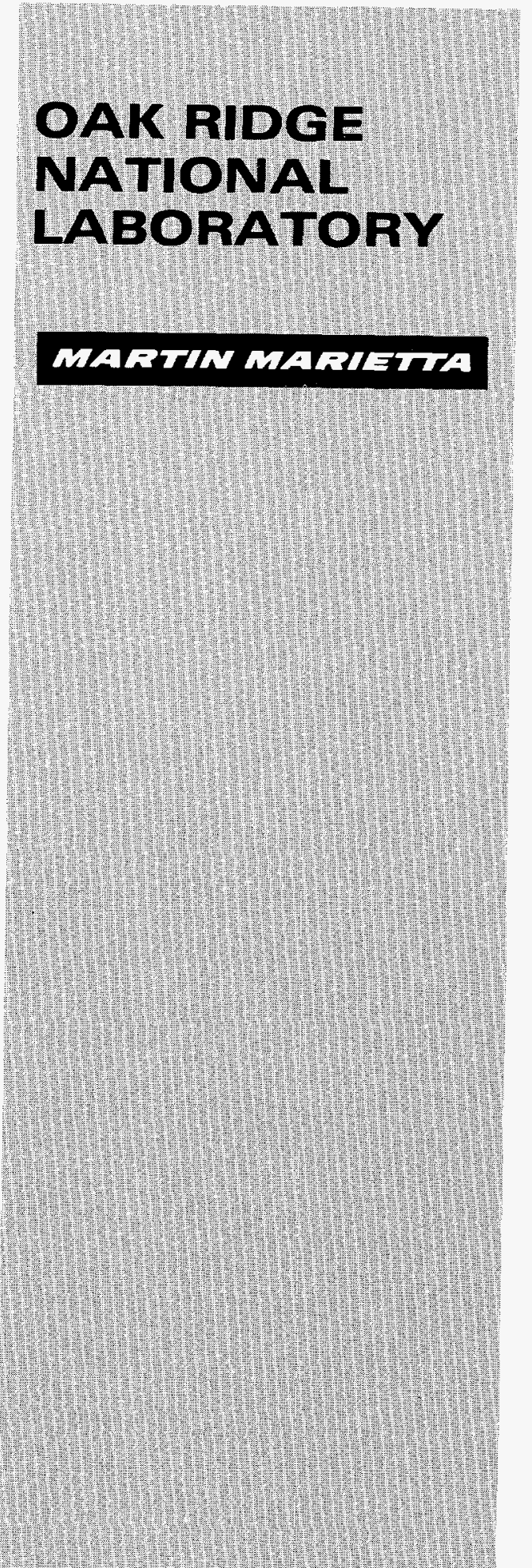

MANAGEO BY

MARTIN MARIETTA ENERGY SYSTEMS, INC.

FOR THE UNITEO STATES

DEPARTMENT OF ENERGY

\section{Measurements for the Jasper Program Intermediate Heat Exchanger Experiment}

\author{
F. J. Muckenthaler \\ R. R. Spencer \\ H. T. Hunter \\ J. L. Hull \\ A. Shono
}

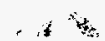

DISTRASTION OF THIS DOCUMENT IS UNULAMTED 
This report has been reproduced directly from the best available copy.

Available to DOE and DOE contractors from the Office of Scientific and Technical Information, P.O. Box 62, Oak Ridge, TN 37831; prices available from (615) 576-8401, FTS 626-8401.

This report was prepared as an account of work sponsored by an agency of the United States Government. Neither the United States Government nor any agency thereor, nor any of their employees, makes any warranty, express or implied, or assumes any legal liability or responsibility for the accuracy, completeness, or usefulness of any information, apparatus, product, or process disclosed, or represents that its use would not infringe privately owned rights. Reference herein to any specific commercial product, process, or service by trade name, trademark, manufacturer, or otherwise, does not necessarily constitute or imply its endorsement, recommendation, or favoring by the United States Government or any agency thereof. The views and opinions of authors expressed herein do not necessarily state or reflect those of the United States Government or any agency thereof. 
Engineering Physics and Mathematics Division

\author{
MEASUREMENTS FOR THE JASPER PROGRAM \\ INTERMEDIATE HEAT EXCHANGER EXPERIMENT
}

\author{
F. J. Muckenthaler \\ R. R. Spencer \\ H. T. Hunter \\ J. L. Hull" \\ A. Shono**
}

Date Published: July 1992

Oak Ridge National Laboratory

Oak Ridge, Tennessee 37831-6363

Prepared for the

U.S. DOE Office of

Liquid Metal Converter Reactor

"Research Reactors Division

**Japan Power Reactor and Nuclear Fuel Development Corporation

\title{
DISCLAIMER
}

This report was prepared as an account of work sponsored by an agency of the United States Government. Neither the United States Government nor any agency thereof, nor any of their employees, makes any warranty, express or implied, or assumes any legal liability or responsibility for the accuracy, completeness, or usefulness of any information, apparatus, product, or process disclosed, or represents that its use would not infringe privately owned rights. Reference herein to any specific commercial product, process, or service by trade name, trademark, manufacturer, or otherwise does not necessarily constitute or imply its endorsement, recommendation, or favoring by the United States Government or any agency thereof. The views and opinions of authors expressed herein do not necessarily state or reflect those of the United States Government or any agency thereof.

\author{
Prepared by the \\ OAK RIDGE NATIONAL LABORATORY \\ Oak Ridge, Tennessee 37831 \\ managed by \\ MARTIN MARIETTA ENERGY SYSTEMS, INC. \\ for the \\ U.S. Department of Energy \\ under contract DE-AC05-84OR21400
}


1 


\section{DISCLAMMER}

Portions of this document may be illegible in electronic image products. Images are produced from the best available original document. 


\section{TABLE OF CONTENTS}

\section{$\underline{\text { Page }}$}

List of Tables $\ldots \ldots \ldots \ldots \ldots \ldots \ldots \ldots \ldots \ldots \ldots \ldots \ldots \ldots \ldots \ldots$

List of Figures $\ldots \ldots \ldots \ldots \ldots \ldots \ldots \ldots \ldots \ldots \ldots \ldots \ldots \ldots \ldots \ldots \ldots \ldots \ldots$

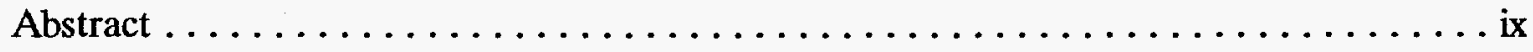

1. Introduction $\ldots \ldots \ldots \ldots \ldots \ldots \ldots \ldots \ldots \ldots \ldots \ldots \ldots \ldots \ldots \ldots$

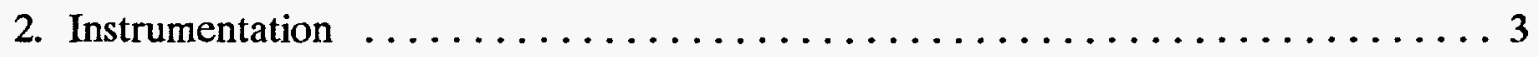

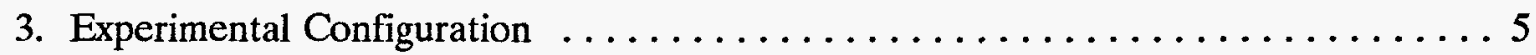

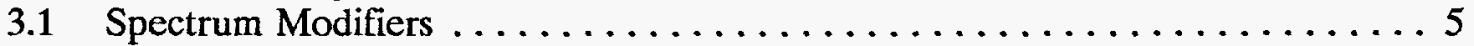

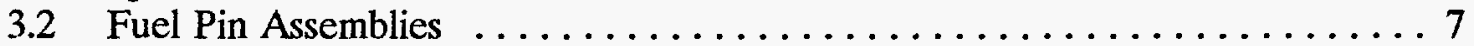

3.3 Boron Carbide Slabs $\ldots \ldots \ldots \ldots \ldots \ldots \ldots \ldots \ldots \ldots \ldots \ldots \ldots \ldots$

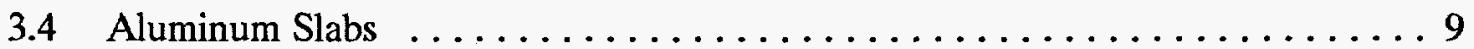

3.5 Background Shields . . . . . . . . . . . . . . . . . . . 9

3.6 Homogeneous IVFS Vessel (No Fuel) $\ldots \ldots \ldots \ldots \ldots \ldots \ldots \ldots \ldots \ldots \ldots$

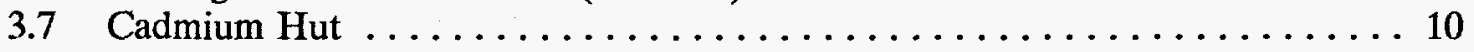

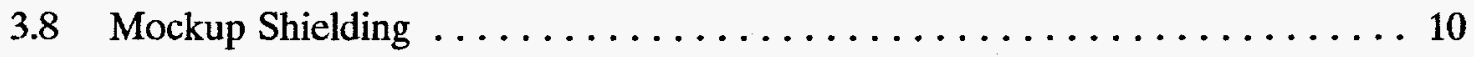

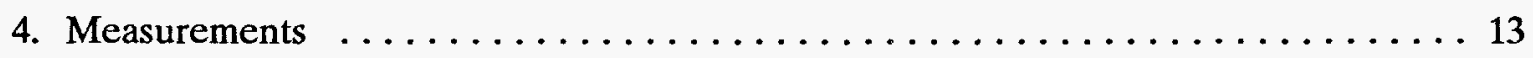

4.1 Spectrum Modifiers (Items IA, IAA, IB) $\ldots \ldots \ldots \ldots \ldots \ldots \ldots \ldots \ldots \ldots \ldots \ldots \ldots \ldots$

4.2 ALMR Mockups Below Spent Fuel Region (Items IIA-F) . . . . . . . . . 16

4.3 ALMR Mockups in Spent Fuel Region (Items IIIA-E) . . . . . . . . . . 17

4.4 ALMR Mockups for Fission Gas Plenum Region of Spent Fuel (Items IVA-E) . . . . . . . . . . . . . . . . . . . . . 18

4.5 IHX Mockup (Sodium with Sodium Side Slabs)

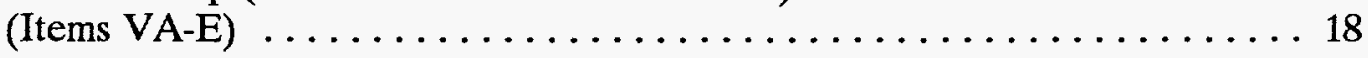

4.6 IHX Mockup (Boron Carbide Front Shield - Sodium Side Slabs) (Items VIA-E) . . . . . . . . . . . . . . . . 20

4.7 IHX Mockup (Boron Carbide Front Shield - Partial Side Shield) (Items VIIA-F) $\ldots \ldots \ldots \ldots \ldots \ldots \ldots \ldots \ldots \ldots \ldots \ldots \ldots \ldots . \ldots \ldots$

4.8 IHX Mockup (Boron Carbide Front Shield - Boron Carbide Side Shield) (Items VIIIA-F) . . . . . . . . . . . . . . . . 21

4.9 IHX Mockup (Boron Carbide Front Shield with Aluminum Window - Boron Carbide Side Shield) (Items IXA-E) . . . . . . . . 21

4.10 IHX Mockup with Solid Boron Carbide/Aluminum Front Shield and Full Boron Carbide Side Shields (Items XA-E) . . . . . . . . 22

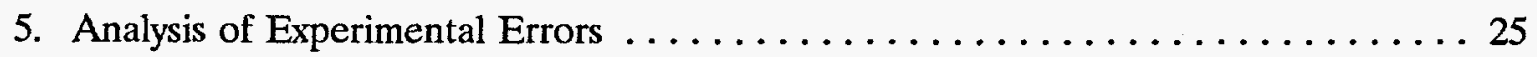

Acknowledgements $\ldots \ldots \ldots \ldots \ldots \ldots \ldots \ldots \ldots \ldots \ldots \ldots \ldots \ldots \ldots \ldots \ldots$ 
Appendix A. Experimental Program Plan for the JASPER Intermediate

Heat Exchanger Experiment

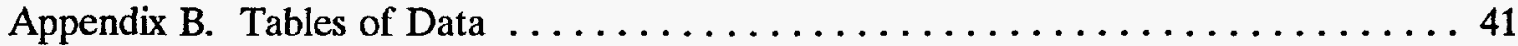

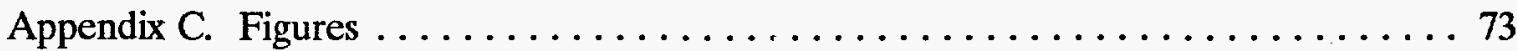




\section{LIST OF TABLES}

$\underline{\text { Page }}$

Table 1. Analysis of iron slabs $(\rho=7.86 \mathrm{~g} / \mathrm{cc})$ used in spectrum modifier $\ldots . .43$

Table 2. Analysis of 6061 aluminum $(\rho=2.70 \mathrm{~g} / \mathrm{cc}) \ldots \ldots \ldots \ldots$

Table 3. Composition of boral slabs used in spectrum modifier $\ldots \ldots \ldots 44$

Table 4. $\quad$ Composition of rectangular sodium slabs $(\rho=0.945 \mathrm{~g} / \mathrm{cc}) \ldots \ldots 44$

Table 5. Composition of the small concrete blocks on each side of the

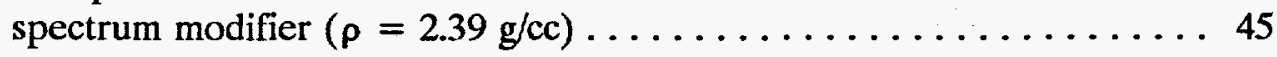

Table 6. Analysis of $61-\mathrm{cm} \times 61-\mathrm{cm} \times 30.5-\mathrm{cm}(\rho=2.40 \mathrm{~g} / \mathrm{cc})$ concrete blocks used to surround configuration $\ldots \ldots \ldots \ldots \ldots \ldots \ldots \ldots$

Table 7. Analysis of concrete slabs on top of the mockup $(\rho=2.68 \mathrm{~g} / \mathrm{cc}) \ldots \ldots 47$

Table 8. Composition of lithiated-paraffin bricks $(\rho=1.15 \mathrm{~g} / \mathrm{cc}) \ldots \ldots 4$

Table 9. Maximum impurities in the cylindrical sodium slab $(\rho=0.945 \mathrm{~g} / \mathrm{cc}) \ldots 48$

Table 10. Analysis of concrete around the cylindrical sodium tanks . . . . . . 49

Table 11. Analysis of boron carbide used in shield mockups $\ldots \ldots \ldots \ldots$

Table 12. Analysis of type 304 stainless steel in boron carbide containers

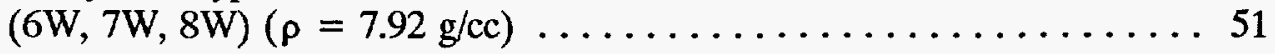

Table 13. Analysis of lead slabs $(\rho=11.35 \mathrm{~g} / \mathrm{cc}) \ldots \ldots \ldots \ldots \ldots \ldots \ldots$

Table 14. Bonner ball measurements on centerline at $30 \mathrm{~cm}$ behind a series of configurations . ...................... 53

Table 15. Bonner ball measurements on centerline at $150 \mathrm{~cm}$ behind a series of configurations . ....................... 55

Table 16. Sodium foil measurements in voids located in the spectrum modifiers . . 59

Table 17. Fast neutron spectrum $(>0.8 \mathrm{MeV})$ on centerline at $25 \mathrm{~cm}$ behind the lead slabs (Item IB) Run 7923.A . . . . . . . . . . . . 60

Table 18. Neutron spectrum ( $50 \mathrm{keV}$ to $1.4 \mathrm{MeV})$ on centerline at $25 \mathrm{~cm}$ behind the lead slabs (Item VB) (Runs 1593.C, 1593.A, 1593.B) . . . . . . 61 
Table 19. Bonner ball measurements on centerline at NE-213 location behind spectrum modifier (Item IB) $\ldots \ldots \ldots \ldots \ldots \ldots \ldots$

Table 20. 5-inch Bonner ball horizontal traverse through midplane at $30 \mathrm{~cm}$ behind spectrum modifier (Item IB) $\ldots \ldots \ldots \ldots \ldots \ldots \ldots \ldots \ldots$

Table 21. Bare Bonner ball measurements on centerline at $30 \mathrm{~cm}$ behind a series of configurations

Table 22. Bare Bonner ball measurements on centerline at $150 \mathrm{~cm}$ behind a series of configurations

Table 23. Sodium foil measurements in voids located throughout configuration mockups

Table 24. Bonner ball horizontal traverses through midplane at $30 \mathrm{~cm}$ behind the shield mockup (Item XE) 


\section{LIST OF FIGURES}

$\underline{\text { Page }}$

Figure 1. A photograph of a typical IHX shield mockup $\ldots \ldots \ldots \ldots$

Figure 2. Schematic of SM-2 (iron + aluminum + boral + sodium). Item IA $\ldots 76$

Figure 3. Schematic of aluminum containers filled with sodium $\ldots \ldots \ldots 77$

Figure 4. $\quad$ Schematic of SM-3 (sodium) plus lead. Item IB $\ldots \ldots \ldots \ldots \ldots$

Figure 5. A photograph of a typical sodium-filled, aluminum-walled cylindrical vessel used in SM-3 ................ 79

Figure 6. Isometric of the SPERT fuel rod containing uranium-dioxide fuel pellets $\ldots \ldots \ldots \ldots \ldots \ldots \ldots \ldots \ldots \ldots \ldots \ldots \ldots . \ldots \ldots \ldots$

Figure 7. Schematic of Homogeneous IVFS Mockup (Slab \#3) $\ldots \ldots \ldots 1$

Figure 8. Schematic of stainless steel containers used for boron-carbidefilled shield slabs . . . . . . . . . . . . . . . . 82

Figure 9. Schematic of stainless steel containers used for boron-carbidefilled shield slabs $\ldots \ldots \ldots \ldots \ldots \ldots \ldots \ldots \ldots \ldots \ldots \ldots$

Figure 10. Schematic of aluminum slabs (dimensions in $\mathrm{cm}$ ) $\ldots \ldots \ldots \ldots 4$

Figure 11. Schematic of sodium foil locations within mockups. Items IA, IAA, IB, VE, VIE, VIIF, VIIIF, IXE, XE ............. 85

Figure 12. Schematic of SM-2 (iron + aluminum + boral + sodium) for foil run.

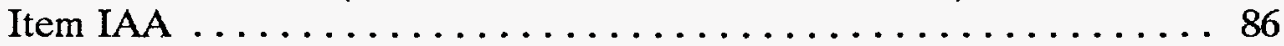

Figure 13. Spectrum of high-energy neutrons $(>0.8 \mathrm{MeV})$ on centerline at $25 \mathrm{~cm}$ behind the lead slab (Item IB) Run 7923A . . . . . . . 87

Figure 14. Neutron spectrum (50 keV to $1.4 \mathrm{MeV}$ ) on centerline at $25 \mathrm{~cm}$ behind the lead slabs (Item IB) Runs 1593C, 1593A, 1593B ....... 88

Figure 15. Schematic of SM-2 plus shield configurations for Item II . . . . . . 89

Figure 16. Schematic of SM-2 plus shield configurations for Item III . . . . . . 90

Figure 17. Schematic of SM-2 plus shield configurations for Item IV . . . . . 91

Figure 18. Schematic of SM-3 plus shield configurations for Item $\mathrm{V} \ldots \ldots 2$ 
Figure 19. Schematic of SM-3 plus shield configurations for Item VI . . . . . 93

Figure 20. Schematic of SM-3 plus shield configurations for Item VII $\ldots \ldots \ldots 94$

Figure 21. Schematic of SM-3 plus shield configurations for Item VIII . . . . . 95

Figure 22. Schematic of SM-3 plus shield configurations for Item IX . . . . . 96

Figure 23. Schematic of SM-3 plus shield configurations for Item $X \ldots \ldots 7$

Figure 24. Schematic of SM-3 plus shield configuration for radial traverses beyond mockup in Item $\mathrm{X} \ldots \ldots \ldots \ldots \ldots \ldots \ldots \ldots \ldots \ldots$ 


\begin{abstract}
The Intermediate Heat Exchanger (IHX) experiment was conducted at the Oak Ridge National Laboratory (ORNL) Tower Shielding Facility (TSF) during the last three months of 1991 and the first two months of 1992 as part of a continuing series of eight experiments planned for the Japanese-American Shielding Program for Experimental Research (JASPER) program that was started in 1986. This is the fifth experiment in that series, all of which are intended to provide support in the development of current reactor shield designs proposed for liquid metal reactor (LMR) systems both in Japan and the United States. The program is a cooperative effort between the United States Department of Energy (U.S. DOE) and the Japanese Power Reactor and Nuclear Development Corporation (PNC).

The experimental configurations consisted of a neutron spectrum modifier followed by various shield mockups. For the PNC portion of the program the modifier was a large volume of sodium typical of the area in which their IHX vessel would be located radially from the reactor core. Configurations studied in the U.S. part of the program were preceded by the same modifier of iron, aluminum, boral, and sodium used with the Advanced Liquid Metal Reactor (ALMR) mockups in the previous In-Vessel Fuel Storage (IVFS) experiment. This modifier was followed by mockups representative of three different off-axial locations that were being considered for placement of the IHX vessel. The PNC plan was concerned with the effort of surrounding a mockup of the sodium containing IHX vessel by a partial or full component boron carbide $\left(\mathrm{B}_{4} \mathrm{C}\right)$ shield.
\end{abstract}




\section{INTRODUCTION}

This experiment is the fifth in a series of eight experiments to be performed at the TSF that were jointly planned by ORNL, participant for the U.S. DOE, and the PNC. This phase of the program, called the IHX experiment, was preceded by the Radial Shield Attenuation and Fission Gas Plenum experiments completed in 1986-87, the Axial Shield experiment completed in 1990, and the IVFS experiment completed in 1991.

The IHX experiment was designed to investigate and predict the sodium activation that will be generated in the secondary sodium contained within the IHX vessel. In reactor shield designs of the proposed type to be studied, calculation and prediction of the secondary coolant activation is most difficult because of the associated structure present and the resulting problems associated with defining the neutron paths in that area.

In this experiment two somewhat similar spectrum modifiers were used. For the U.S. portion of the program plan, the same sodium-pool-type modifier used in the IVFS study was utilized. This was followed by slabs of aluminum $(\mathrm{Al})$, sodium $(\mathrm{Na}), \mathrm{B}_{4} \mathrm{C}$, and in one study, stored fuel pins, that were placed in proper sequence to represent three different off-axial locations of the IHX vessel below the stored fuel, in the stored fuel area, and the Gas Plenum region of stored fuel. The modifier for the Japanese study was similar in nature, consisting only of sodium, which was followed by slabs of sodium representing the IHX vessel contained in a partial or full $\mathrm{B}_{4} \mathrm{C}$ shield mockup.

The fuel pins are the same $4.81 \mathrm{wt} \%{ }^{235} \mathrm{U}$ enriched rods that were contained in the so-called "homogeneous" vessel used in the previous IVFS experiment. Measurements were made behind it and the other slabs as they were placed in the horizontal neutron beam emanating from the Tower Shielding Reactor (TSR-II) as described in the program plan in Appendix A. 



\section{INSTRUMENTATION}

The TSF Bonner ball detection system consists of a series of detectors (polyethylene balls), each of which measures an integral of the neutron flux weighted by the energy-dependent response function for that ball. The detection device of a Bonner ball consists of a 5.1-cm-diameter spherical proportional counter filled with $\mathrm{BF}_{3}$ gas $\left({ }^{10} \mathrm{~B} / \mathrm{B}\right.$ concentration $=0.96$ ) to a pressure of 0.5 atmospheres. In order to cover a range of neutron energies, the counter is used bare, covered with cadmium ( $\mathrm{Cd}$ ), or enclosed in various thicknesses of polyethylene shells surrounded by $\mathrm{Cd}$, each detector being identified by the diameter of its shell. Bonner ball experimental results are predicted analytically by folding a calculated neutron spectrum with the Bonner ball response functions determined by R. E. Maerker et al. ${ }^{1}$ and C. E. Burgart et al. ${ }^{2}$

An NE 213 liquid scintillator spectrometer covered the neutron spectral region from about 800 to $15 \mathrm{MeV}$. This device makes use of pulse-shape discrimination (PSD) to distinguish neutrons from gamma-ray pulses. Pulse-height data obtained with the spectrometer were unfolded with the FERD code ${ }^{3}$ to yield absolute neutron energy spectra.

Spherical proton-recoil counters, filled with hydrogen to pressures of 1,3 , and 10 atmospheres, covered the neutron energy range from about $50 \mathrm{keV}$ to $1 \mathrm{MeV}$. Pulseheight data from the counters were unfolded with the SPEC- 4 code, ${ }^{4}$ which makes use of the unfolded NE-213 neutron spectrum to correct for effects of higher-energy neutrons.

The measurements for each detector were referenced to the reactor power (watts) using the data from two fission chambers positioned along the reactor centerline as a basis. The response of these chambers as a function of reactor power level was established previously through several calorimetric measurements of the heat generated in the reactor during a temperature equilibrium condition (heat power run).

A study of the activation of the sodium in the spectrum modifier and in the shield mockups that followed was made using sodium carbonate- $\left(\mathrm{Na}_{2} \mathrm{CO}_{3}\right)$ filled polystyrene capsules. The gamma-ray activity of the sodium within the capsules was measured by $\mathrm{J}$. $\mathrm{K}$. Dickens ${ }^{5}$ utilizing a well-shielded Ge (Li) detector of $15 \%$ efficiency for a gamma-ray energy of $1.33 \mathrm{MeV}$ when compared to a $7.5-\mathrm{cm} \times 7.5-\mathrm{cm} \mathrm{NaI}$ detector. The detector has a nominal resolution of about $2.5 \mathrm{keV}$ for a gamma-ray energy of $1.33 \mathrm{MeV}$. The sodium activities experienced during the runs varied by more than four orders of magnitude from 
a low of about $16 \mathrm{~Bq}$ to nearly $10^{5} \mathrm{~Bq}$. For this range of activity, the overall absolute uncertainty assigned to the capsule activity was $\pm 5 \%$. 


\section{EXPERIMENTAL CONFIGURATION}

The experimental program plan is essentially divided into three parts that list the mockups for the two spectrum modifiers, the three U.S.-sponsored axial locations of the IHX vessel, and the Japanese model where the IHX vessel is surrounded by partial or full complement shields. Neutron flux measurements were made behind each of the mockups as described in the program plan and sodium activation studies were made within both spectrum modifiers and between the mockup slabs in each of the Japanese model IHX configurations where feasible.

The U.S. design included configurations that began with the same sodium-pooltype spectrum modifier that was used in the previous IVFS experiment, followed by mockups that simulated the IHX vessel at three different off-axial locations. The regions selected represented locations below the spent fuel, at the spent fuel, and the fission gas plenum region of the spent fuel.

Configurations for the Japanese models began with a simple spectrum modifier of sodium followed by a simulated IHX vessel composed of a maximum of four sodium slabs, with and without a $\mathrm{B}_{4} \mathrm{C}$ slab preceding them. These combinations were surrounded on two sides by additional sodium or a combination of sodium and $\mathrm{B}_{4} \mathrm{C}$ that was considered to be part of the study. One of the mockups included a $\mathrm{B}_{4} \mathrm{C}$ slab in front of the sodium slabs that had a cylindrical opening to represent a sodium inlet pipe into the IHX. A special mockup (see Item $\mathrm{X}$ ) was included in the program plan to provide a benchmark mockup combining $\mathrm{B}_{4} \mathrm{C}$ and aluminum that would provide a more stringent test of the three-dimensional transport codes developed in the U.S. and Japan.

The neutron source for all the measurements in the IHX experiment was the TSR-II placed in its Big Beam Shield that collimated the neutrons leaving the reactor into a horizontal beam through the use of a concrete shutter. The mockup slabs were centered on this horizontal beam and surrounded by concrete to reduce the background contribution. Measurements were made behind each of the slabs as it was added to the mockup, using a traversing mechanism that remotely positioned the detector while the reactor power was maintained. A typical mockup is pictured in Figure 1.

\subsection{SPECTRUM MODIFIERS}

Two different spectrum modifiers, noted in the program plan as SM-2 and SM-3, 
were necessary to provide the proper neutron distribution incident on the mockups for the U.S. DOE and PNC phases of the experiment. The first of these, SM-2, is the same modifier that was used in the previous IVFS experiment (see ORNL/TM-11989). The modifier, see Figure 2, consisted of two slabs of iron, 5.16 and $5.11 \mathrm{~cm}$ thick, followed by $9.17 \mathrm{~cm}$ of aluminum, $2.54 \mathrm{~cm}$ of boral, and $180 \mathrm{~cm}$ (nominal value) of sodium. The iron, aluminum, and boral slabs are $152.4 \mathrm{~cm}$ on an edge, while the sodium slab edges (including the aluminum vessel itself) are $2.54 \mathrm{~cm}$ wider. The actual thickness of the sodium slabs, shown in Figure 3, varied from the edge of the slabs to the middle, as there was some bulging along the slab centerlines. The centerline thickness for each slab in the modifier is also given in the lower left portion of the slabs shown in the schematics. Compositions of the iron, the type 6061 aluminum used throughout this experiment in the slabs and sodium tanks, and boral slabs are given in Tables 1, 2, and 3 respectively. The 30.5-cm-thick sodium slabs were obtained from Atomics International during the 1960s and have been used previously in various TSF experiments. The composition of the sodium is given in Table 4. This modifier preceded the mockups for the U.S. DOEsponsored ALMR shield studies listed in the program plan as Items II, III, and IV. (Note: All tables are located in Appendix B).

The sides of the modifier SM-2 and all succeeding slabs used throughout the U.S. DOE-sponsored mockups were surrounded with lithiated paraffin whose thicknesses on all sides was not the same. The lithiated paraffin thickness against the vertical sides of the slabs was limited to $10.16 \mathrm{~cm}$ because of the number of bricks available at the TSF for the whole mockup. The configuration slabs were supported by a slab having one face of lithiated paraffin $20.3 \mathrm{~cm}$ thick in contact with the mockup slabs, the reverse side being $10.2 \mathrm{~cm}$ of concrete. Due to the tie-off pieces necessary at the top of each configuration slab, the thickness of lithiated paraffin in that area varied from 20 to $30 \mathrm{~cm}$. In all cases, the lithiated paraffin on each edge of the slab was surrounded by a minimum of $61 \mathrm{~cm}$ of concrete. The concrete beyond the lithiated paraffin lining the vertical sides of the $\mathrm{Fe}, \mathrm{Al}$, and boral slabs consisted of concrete blocks, $15.24 \times 15.24 \times 30.48 \mathrm{~cm}$, that were stacked to a radial depth of $61 \mathrm{~cm}$, followed by other concrete as shown in the schematics. The composition of these small blocks is given in Table 5. The concrete adjacent to the lithiated paraffin bricks at the sides of the sodium tanks was of the $61-\mathrm{x} 61-\mathrm{x} 30.48-\mathrm{cm}$ size and the composition of these is given in Table 6. The concrete covering the top of 
the spectrum modifier was in slab form and the analysis of this concrete is in Table 7. Additional concrete was added at the sides and over the top of the SM to reduce the background neutrons reaching the detector. The composition of the lithiated paraffin is given in Table 8.

The second modifier, SM-3, consisted of a combination of two 335.3-cm-diameter, cylindrical aluminum tanks filled with sodium, having thicknesses of 76.0 and $160.6 \mathrm{~cm}$ as measured on beam centerline (cylindrical centers). The aluminum faces of the cylinders were $1.27 \mathrm{~cm}$ thick, and this is included in the centerline measurement as quoted in the schematics in Figure 4. Concrete at least $45.7 \mathrm{~cm}$ thick surrounded the periphery of the tanks to reduce the effects of transverse leakage from the tanks. This was again followed by additional concrete to reduce background neutrons.

The sodium density was determined for previous usage by placing the tank between a 3-inch $\mathrm{NaI}$ detector and a ${ }^{24} \mathrm{Na}$ source and measuring accurately the counting rates in the uncollided gamma-ray peak at $2.75 \mathrm{MeV}$. From the ratio of this counting rate to the counting rate in this peak with no tank present and using the mass absorption coefficient for that energy gamma ray, the sodium density was determined to be an average of $0.945 \mathrm{~g} / \mathrm{cc}$ for the two tanks. It was estimated that this value should be accurate to better than $1 \%$. The maximum impurities in the sodium estimated by the vendor are presented in Table 9. A photograph of the tanks is given in Figure 5. Analysis of the concrete immediately surrounding the sodium is given in Table 10.

It should be noted that throughout the program plan in Appendix A, the material thickness mentioned for each slab is usually a nominal value. The actual thickness, in centimeters, for each slab is located in the left corner of that slab as it is displayed in the schematics in Appendix C. The values quoted represent the thickness of the slab, including the vessel walls, along the centerline of the slab. The center of the slabs coincided with the center of the reactor beam when placed in the mockup.

\subsection{FUEL PIN ASSEMBLIES}

A total of 1200 fuel pins were secured from the University of Florida for use in the preceding IVFS experiment and in this experiment. The pins were originally fabricated for use at the United States Atomic Energy Commission's National Reactor Testing Station near Idaho Falls, Idaho, for Special Power Excursion Reactor tests, hence the acronym SPERT fuel. Each of the rods consists of slightly enriched (4.81\%), sintered 
Uranium Oxide $\left(\mathrm{UO}_{2}\right)$ pellets encased in a 304 stainless steel (SS) tube and capped at both ends with SS. In each rod there exists an aluminum oxide $\left(\mathrm{Al}_{2} \mathrm{O}_{3}\right)$ insulator between the $\mathrm{UO}_{2}$ pellets and the SS caps at each end. Gas gaps for fuel expansion are provided at the upper end of the rod and around the pellets. A spring is located atop the fuel pellets to keep the pellets in place. The characteristics of a typical SPERT fuel rod may be seen, along with the schematic, in Figure 6. As is noted in the figure, the active fuel length is $91.44 \mathrm{~cm}$, with an overall length of the fuel rod, ends included, of $106.05 \mathrm{~cm}$. The pellets are $1.067 \mathrm{~cm}$ in diameter, and are clad in 1.184-cm-OD SS tubing with walls $0.051 \mathrm{~cm}$ thick. The $\mathrm{UO}_{2}$ fuel pellet density is $10.08 \mathrm{~g} / \mathrm{cc}$ and the ${ }^{235} \mathrm{U}$ in each rod amounts to 35.2 grams. Each of the pins is numbered to enhance record keeping. What was not noted in the schematic is that each of the pins has a weld bead at the top and bottom of the rod where the end caps join the tubing containing the fuel. This weld is slightly larger in diameter $(1.20 \mathrm{~cm})$ than the SS tubing $(1.184 \mathrm{~cm})$, and this larger diameter required some last minute changes in the fabrication of the vessels.

The fuel pins for this experiment were contained in what was referred to as the homogeneous vessel in the IVFS experiment. The expression "homogeneous" relates to the more general pin-aluminum distribution that occurred while maintaining the same fuelto-aluminum volume fraction ratio that occurred in a more heterogeneous slab. In this arrangement (see Figure 7) the 536 pins were split into two groups by a 3.46-cm-thick aluminum divider that ran the full width of the vessel. On one side of the divider were two rows each of 77 and 76 pins stacked vertically, while on the other side were two rows of 77 pins and one row of 76 pins. The pins were spaced on a triangular pitch of $1.20 \mathrm{~cm}$ based on the diameter of the welds.

When the homogeneous vessel was placed in the mockup, it was necessary to place additional support beneath it to center the vessel on the reactor beam centerline since the length of the vessel was only $111.19 \mathrm{~cm}$ compared to the usual slab height of $152.4 \mathrm{~cm}$. This was accomplished using $20.3 \mathrm{~cm}$ of lithiated paraffin. Likewise, since the width of the vessel, $97.38 \mathrm{~cm}$, was also less than the usual slab width, $152.4 \mathrm{~cm}$, it was necessary to fill the void beyond the vessel with lithiated paraffin bricks.

\subsection{BORON CARBIDE SLABS}

The $\mathrm{B}_{4} \mathrm{C}$ slabs used in this experiment consisted of stainless steel cans filled with 120 grit $\mathrm{B}_{4} \mathrm{C}$ powder. Six different containers were used, three of which were used in the 
previous IVFS experiment. These were noted as $4 \mathrm{~W}$ and $5 \mathrm{~W}$, nominally $5 \mathrm{~cm}$ thick, and $2 \mathrm{~W}$, nominally $15 \mathrm{~cm}$ thick. The actual thicknesses are given in Figure 8, and the analysis of the $\mathrm{B}_{4} \mathrm{C}$ is given in Table 11. All slabs were $152.4 \mathrm{~cm}$ on an edge. The densities were $1.39,1.41$, and $1.44 \mathrm{~g} / \mathrm{cc}$ for slabs $2 \mathrm{~W}, 4 \mathrm{~W}$, and $5 \mathrm{~W}$ respectively. Three other $\mathrm{B}_{4} \mathrm{C}$ slabs were fabricated specifically for this experiment. One was of the same thickness, nominally, as that noted for $2 \mathrm{~W}$, but it (see $6 \mathrm{~W}$ in Figure 9) contained a cylindrical void at its center which was filled with an aluminum cylinder (type 6061) for this experiment. The other two slabs ( $7 \mathrm{~W}$ and $8 \mathrm{~W}$ ) were nominally the same thickness as $4 \mathrm{~W}$ and $5 \mathrm{~W}$, but were only half as wide $(76.2 \mathrm{~cm})$. Actual centerline thicknesses of the three slabs are also given in Figure 9, along with their densities and the dimensions of the aluminum insert. Analysis of the stainless steel vessels is given in Table 12.

\subsection{ALUMINUM SLABS}

Thin aluminum slabs were used throughout the spectrum modifier and in the ensuing mockups as a substitute for the sodium coolant in a typical U.S. ALMR reactor design. Special half-slabs of aluminum were fabricated for use in the Japanese series of mockups and these are shown in Figure 10. The slabs are all from the same type of aluminum, 6061, and their composition is listed in Table 2.

\subsection{BACKGROUND SHIELDS}

The procedure in the previous JASPER experiments was to obtain background measurements along with foreground measurements when the detectors were located at sufficient distances behind the mockups and the neutron contributions to that detector from areas other than the mockup being studied might not be negligible. These background measurements were obtained by placing a 40.6-cm-thick, 91.4-cm x 91.4-cm shadow shield of lithiated paraffin bricks between the detector and mockup in such a manner that contributions directly to the detector from just the mockup would be greatly reduced. This procedure was followed in making the measurements requested for the ALMR studies described in Items I through IV in the program plan. For the measurements requested in Items $\mathrm{V}$ through $\mathrm{X}$ of the program plan, PNC requested that the term mockup be extended to include the side $\mathrm{B}_{4} \mathrm{C}$ and sodium tanks placed radially beyond the usual mockup slabs. This extension of the mockup width limited the number of background measurements that could be made using the same shadow shield described 
above to just the thicker mockups where the detector, when located at the $150 \mathrm{~cm}$ point, was adequately beyond the mockup to satisfy the procedure normally applied to obtain a background measurement. This request required changes in the measurements originally planned for the experiment and these changes have been made in the program plan in Appendix A.

Background measurements with the bare detector were extended to include some additional measurements with a sheet of $\mathrm{Cd}$ covering the face of the shadow shield nearest the detector. This measurement was considered important because the closeness of the shield to the detector might possibly contribute, through backscattering, to the detector count rate. This contribution can be estimated from the difference in the two background measurements.

\subsection{HOMOGENEOUS IVFS VESSEL (NO FUEL)}

The Homogeneous IVFS Vessel without the fuel pins was originally included as part of this mockup in Item IV. Since the fuel pins were absent and the dimensions of the vessel required the addition of extra lithiated paraffin bricks around its edges to extend its dimensions to $152.4 \mathrm{~cm}$ (standard slab size), the vessel was mocked up with 152.4-cm-on-edge slabs of equivalent aluminum and void thicknesses. The thicknesses used can be found in the schematic for Item IVA-E.

\subsection{CADMIUM HUT}

The Cd hut used in this experiment for making bare Bonner ball measurements at $30 \mathrm{~cm}$ behind the mockup may best be described as a small structure, approximately 152.4 $\mathrm{cm}$ on an edge, closely matching the dimensions of the mockup slabs, and $45.7 \mathrm{~cm}$ deep. The Al frame was covered with $30-40$ mils of $\mathrm{Cd}$, except for one face which was always open to the mockup. The open face allowed thermal neutron entry from the mockup slab while at the same time the $\mathrm{Cd}$ denied thermal neutron entry from any other direction. Thus it was possible to place the bare detector within the hut, make a measurement, and through a subtraction of the Cd-covered detector measurement at the same location, obtain a measure of the thermal flux leaving the mockup.

\subsection{MOCKUP SHIELDING}

The various slabs comprising the mockups were supported by several concrete 
slabs, stacked so that the center of the mockup slabs was coincidental with the reactor beam centerline. The support slab in immediate contact with the mockup pieces was 30.5 $\mathrm{cm}$ thick, $20.3 \mathrm{~cm}$ of which was a layer of lithiated paraffin while the remaining $10.2 \mathrm{~cm}$ was concrete. Throughout the experiment the lithiated paraffin side of the slab was placed next to the mockup. For the mockups studied in Items I through IV, there was $10.2 \mathrm{~cm}$ of lithiated paraffin placed on the lateral sides of each slab as it was added to the mockup. This was followed by an extended thickness of concrete. Both the lithiated paraffin and the concrete pieces usually protruded beyond the depth of the mockup, providing surfaces from which neutrons passing through the mockup slabs could be scattered back to the detector. The void space between the top of the slabs and the concrete roof was filled with $20-30 \mathrm{~cm}$ of lithiated paraffin. Again the sizes of the concrete roof slabs usually resulted in concrete protruding beyond the lithiated paraffin, providing another neutron reflection surface.

The same procedure was followed for the Japanese part of the program, Items $\mathrm{V}$ through $\mathrm{X}$, except the term "mockup" in this series included the sodium and $\mathrm{B}_{4} \mathrm{C}$ slabs placed parallel to the beam centerline on each side of the "usual" mockup slabs. As a result, the lithiated paraffin bricks on the sides were stacked outside the enlarged mockups, followed by a considerable thickness of concrete. The void spaces above the sodium and $\mathrm{B}_{4} \mathrm{C}$ slabs on the sides were also filled with lithiated paraffin and this arrangement was maintained regardless of the number of sodium slabs present as the IHX mockup. Again the concrete roof slabs projected beyond the maximum mockup thickness and the space between it and the tops of each IHX slab as they were added to the mockup was filled with lithiated paraffin. Thus, when the sodium slabs were not present, the concrete slabs became one side of the mockup cavity that remained and, thus, an important reflective surface for neutrons. 



\section{MEASUREMENTS}

The typical mockup consists of a series of slabs, $152.4 \mathrm{~cm}$ on a side, that are stacked in proper sequence for a particular measurement as called for in the program plan. The slabs are usually surrounded with lithiated paraffin bricks followed by concrete to provide both a reasonable boundary for calculation of the albedo neutrons reflected back into the mockup and a satisfactory shield for minimizing the effect of background contribution to the measurement. A $20.3 \mathrm{~cm}$ thickness of lithiated paraffin is preferred, but for this experiment the thickness along the lateral edges was limited to $10.16 \mathrm{~cm}$ because the number of bricks available to cover the larger mockups was inadequate. There was, however, $20.3 \mathrm{~cm}$ of lithiated paraffin beneath the mockup slabs as that amount is inherently part of the concrete slab that supports the mockup. The amount of lithiated paraffin between the top of the mockup slabs and the concrete slabs placed overhead for background suppression varied but was usually never less than $20-30 \mathrm{~cm}$.

Concrete pieces beyond the lithiated paraffin at the sides of the mockups varied from small blocks $15.24 \mathrm{~cm}$ square by $30.5 \mathrm{~cm}$ alongside the SM to larger 61-cm-square by 30.5-cm-thick blocks beside the mockup slabs. Larger concrete blocks $(91 \mathrm{~cm} \mathrm{x} 91 \mathrm{~cm})$ were used to extend the background attenuation but their presence did not contribute to the neutron flux reflected back into the mockup.

The spectrum modifier required in Item IA was the same slab arrangement of Fe, $\mathrm{Al}$, boral, and $\mathrm{Na}$ used in the previous In-Vessel Fuel Storage (IVFS) experiment. The homogeneous vessel with fuel pins used in that experiment was also part of a mockup in this experiment (see Item III). The measurements in Item III of this IHX experiment were performed as part of the IVFS experiment to limit the number of changes of fuel pins and thus reduce personnel exposure to the radiation level of the fuel pins. The results, however, are included in this report.

One of the requests in Item III in the original program plan called for exposure of sodium foils, as $\mathrm{Na}_{2} \mathrm{CO}_{3}$ powder, between the last two sodium slabs in the mockup. Polystyrene capsules containing 5-6 grams of the powder were exposed for one hour at the maximum reactor power level of one megawatt. The resulting gamma-ray activity of the foils from this exposure was not sufficient to be counted by J. K. Dickens using a Ge (Li) detector. This result changed the exposure requests to what are now stated in the program plan. 
As the experiment progressed, it was recognized that the thermal flux measurements requested in the original program plan were not as definitive as originally conceived. Hence, bare detector measurements were added: (1) inside a Cd hut on centerline at $30 \mathrm{~cm},(2)$ with a $\mathrm{Cd}$ sheet behind the detector at both 30 and $150 \mathrm{~cm}$ when feasible, (3) with a Cd sheet over the face of the mockup, (4) with a Cd sheet beneath the concrete slabs covering the mockup, (5) background measurements with $\mathrm{Cd}$ over the face of the shadow shield, and (6) others as noted in the various data tables.

The background measurements were obtained in the usual manner by placing the lithiated paraffin shadow shield between the detector at $150 \mathrm{~cm}$ and the back face of the mockup in Items I through IV. For such measurements in the remaining items of the plan, V-X, it was requested by PNC that they be limited to just the $150 \mathrm{~cm}$ detector positions for which the shadow shield position would prevent the neutrons leaving the side $\mathrm{B}_{4} \mathrm{C}$ and sodium tanks from reaching the detector unobstructed. In reality, this meant that the side $\mathrm{B}_{4} \mathrm{C}$ and sodium tanks were to be considered as part of the mockup and for the thin mockups having one sodium tank or less, the background measurements would be physically impossible.

For the one spectral measurement requested in this plan, Item IB, it was necessary to place $7.62 \mathrm{~cm}$ of lead between the detector and the large cylindrical sodium tanks to reduce the gamma-ray flux at the detector. The addition of the lead permitted placing the detector close $(25 \mathrm{~cm})$ behind the lead, eliminating the need for a background measurement. The composition of the lead slab is given in Table 13.

The order in which the measurements were performed did not follow the order in which they were listed in the program plan. All of the mockups in Items II, III, and IV used the same spectrum modifier (Item IA) and these items were completed before changing modifiers to Item IB and doing measurements in Items V-X. The order in which the measurements were performed within each of the two groups did not follow the order of the listing in the program plan. The reporting of the data, however, will follow the order in which the program plan is written. The plan in Appendix A reflects only the measurements that were made, not what was originally planned. Throughout this report, the words configuration, item, and mockup are used interchangeably when referring to the contents of the program plan. 


\subsection{SPECTRUM MODIFIERS (Items IA, IAA, IB)}

The program plan called for measurements behind two different spectrum modifiers, listed as SM-2 and SM-3 in Item I. The modifier SM-2 is the same modifier as was used in the previous IVFS experiment to provide a simulated spectrum incident upon the above core area where fuel pins were to be stored in the ALMR design for the U.S. At that time extensive measurements of the neutron flux and spectra were made behind it. Hence, at the start of this experiment, the measurements in IA were limited to those with the bare, Cd-covered, 3-, 5-, 8-, and 10-inch Bonner balls on centerline at $30 \mathrm{~cm}$ (foreground) and $150 \mathrm{~cm}$ (foreground and background) behind the modifier and the sodium activation measurements using $\mathrm{Na}_{2} \mathrm{CO}_{3}$ powder. The results of the Bonner ball measurements are listed in Tables 14 and 15.

The $\mathrm{Na}_{2} \mathrm{CO}_{3}$ foils were located in two voids between the sodium tanks as indicated by the letters $X$ and $Y$, in Item IAA, and $Z$ in Item IA, (see Figures 11 and 12). Locations of the vials within each void is shown to the left of those mockups in Figure 11. The results of the sodium activation measurements are expressed as nanocuries of activation per kilowatt of power and gram of sodium for each minute of exposure. These activation values can be found in Table 16.

The second modifier, SM-3, consisted of two 335.3-cm-diam sodium-filled tanks having $76 \mathrm{~cm}$ and $160.6 \mathrm{~cm}$ thicknesses as measured along the tank centerline. This thickness included the two aluminum faces of $1.27 \mathrm{~cm}$ each. The tanks were separated by a small void to allow insertion of the $\mathrm{Na}_{2} \mathrm{CO}_{3}$ capsules. These tanks provided a sodium pool-type modifier for the Japanese part of the IHX program. A description of the tanks was given earlier in section 3.1. A schematic of the modifier mockup can be found in Figure 4.

Since this modifier was new to the JASPER experiments, considerable effort was exerted to map the neutron spectrum and flux distribution behind it. Spectral measurements were made on centerline behind the bare tanks without presence of any of the mockup structure that was to follow. It was necessary to place two 3.81 -cm-thick lead slabs between the sodium and the NE-213 spectrometer to obtain an acceptable gammaray to neutron count rate. Spectral data was obtained on centerline at $25 \mathrm{~cm}$ behind the lead with both the NE 213 and the hydrogen-filled detectors. At this location the detector was $35 \mathrm{~cm}$ behind the sodium modifiers as indicated in Figure 4. The resulting spectra are 
listed in Tables 17 and 18 and plotted in Figures 13 and 14 respectively. Integral flux measurements with the 3-, 5-, and 10-inch Bonner balls at this same location are listed in Table 19.

Measurements were made with the bare, Cd-covered, 3-, 5-, 8-, and 10-inch Bonner balls on centerline at $30 \mathrm{~cm}$ (foreground) and $150 \mathrm{~cm}$ (foreground and background) behind the mockup with the lead slab removed, and these results are given in Tables 14 and 15. A horizontal traverse was made with the 5 -inch Bonner ball at $30 \mathrm{~cm}$, as measured on centerline, behind the sodium tanks and these results are listed in Table 20.

The $\mathrm{Na}_{2} \mathrm{CO}_{3}$ capsules, three bare and two Cd-covered, were exposed on centerline at points 10 and 11 in the void XX between the two sodium tanks, Item IB, as shown in Figure 11. The resultant activation values are given in Table 16.

\subsection{ALMR MOCKUPS BELOW SPENT FUEL REGION (TTEMS IIA-F)}

The series of mockups in this group, IIA-F, represent a study of the shielding materials and their locations within the shield for the off-axial area below the spent fuel region in the ALMR concept. A schematic of the mockups can be seen in Figure 15. A series of measurements with the bare, Cd-covered, 3-, 5-, 8-, and 10-inch Bonner balls were made on centerline at 30 and $150 \mathrm{~cm}$ behind the last slab in each of the $A$ through $F$ mockups. Foreground measurements only were made at the $30 \mathrm{~cm}$ location, while both foreground and background data were obtained at $150 \mathrm{~cm}$. The data at $30 \mathrm{~cm}$ are listed in Table 14, and that obtained at $150 \mathrm{~cm}$ are contained in Table 15.

Some additional measurements were added in this series that were not called for in the original data plan. These were included in an attempt to help define the foreground and background thermal neutron flux values at the 30 and $150 \mathrm{~cm}$ detector locations. As seen in the program plan, measurements with the bare detector were made on centerline at $30 \mathrm{~cm}$ behind the mockup when located inside a $\mathrm{Cd}$ hut that inhibited entry of the thermal neutrons from every direction except the back face of the mockup. A discussion of the $\mathrm{Cd}$ hut was given earlier in section 3.7. Subtracting the Cd-covered detector count rate from the bare detector measurement at $30 \mathrm{~cm}$ indicates the magnitude of the thermal flux leaving the face of the mockup.

An opposite approach was also employed throughout part of the experiment in which measurements were made with the bare detector when $\mathrm{Cd}$ was placed over the face 
of the mockup. In a way this may be considered a background-type measurement in that the $\mathrm{Cd}$ absorbs the thermal flux leaving the face of the mockup but allows the detector to respond to thermal neutrons from every other possible source. Subtracting the two bare detector runs, with and without $\mathrm{Cd}$ over the face of the mockup, again provides a measure of the thermal flux leaving the mockup. Results from the measurements at $30 \mathrm{~cm}$ using both approaches are given in Table 21, while those results from measurements made at $150 \mathrm{~cm}$ in the last method are in Table 22.

A series of $\mathrm{Na}_{2} \mathrm{CO}_{3}$ foil activation measurements were originally requested to be obtained in voids placed throughout the mockup. This part of the program plan was canceled for Item II following the results of such measurements obtained in Item III, which was the first Item in the IHX series for which these measurements were made. As discussed in section 3 , the large neutron attenuation of that mockup reduced the activity in the foils to values below the sensitivity range of the foil counter. A similar attenuation would have occurred in Item II.

\subsection{ALMR MOCKUPS IN SPENT FUEL REGION (ITEMS IIIA-E)}

The mockups in this group are representative of the shielding materials and their locations within the shield for the off-axial region of the spent fuels. Measurements behind this series of mockups were performed as part of the IVFS experiment, but recorded here, since the use of fuel pins is called for in this series and to have delayed performing these measurements until the IHX experiment would have required another shuffling of the fuel pins into the homogeneous vessel which was already available in the previous IVFS experiment.

Measurements were made with the bare, Cd-covered, 3-, 5-, 8-, and 10-in Bonner balls on centerline at 30 and $150 \mathrm{~cm}$ behind the last slab in each of the mockups $A$ through $E$ as shown in Figure 16. The data at $30 \mathrm{~cm}$ is given in Table 14, that at $150 \mathrm{~cm}$ is included in Table 15 . Measurements with the bare detector at $30 \mathrm{~cm}$ inside the Cd hut were included in the plan and these results are part of Table 21.

As seen in the mockup schematic, a void is shown to exist between sodium tank \#4 and the 2.59-cm-thick stainless steel slab that followed it. The initial run in the IHX experiment was made with $\mathrm{Na}_{2} \mathrm{CO}_{3}$ powder in nine polystyrene capsules located within that void for one hour at a nominal one megawatt of reactor power. Each capsule contained approximately 6 grams of powder and following the run the combination of nine 
capsules failed to indicate enough activation to provide a count rate above the lower limit for the $\mathrm{Ge}(\mathrm{Li})$ detector of one-tenth nanocurie. Because the activation was so low, the exposure of foils as called for in Items I-IV in the original data plan was changed to those noted in the present plan, that is, only within the sodium tanks of the spectrum modifier. Thus no foil exposures were recorded for Item III.

\subsection{ALMR MOCKUPS FOR FISSION GAS PLENUM REGION OF SPENT FUEL (ITEMS IVA-E)}

The mockups chosen for measurements in this group are typical of the shield designs for the Fission Gas Plenum region of the spent fuels. The data plan calls for the homogeneous vessel, without fuel pins, to be placed behind the spectrum modifier. Use of the vessel would have required the presence of lithiated paraffin bricks on its sides to extend the vessel width to be the same as the other slabs, $152.4 \mathrm{~cm}$, and beneath it to place the center of the vessel at the beam centerline. The presence of the bricks, $20.3 \mathrm{~cm}$ in thickness, would have changed the neutron flow in the outer area of the mockup in the slabs that followed it. To promote consistency, the homogeneous vessel was mocked up using slabs of aluminum and void spaces as seen in the schematics in Figure 17. This substitution is not noted in the data plan so that the original concept of the shields to be studied would be maintained.

Measurements with the bare, Cd-covered, 3-, 5-, 8-, and 10-inch Bonner balls were made on centerline at 30 and $150 \mathrm{~cm}$ behind the last slab in each of the five mockup changes called for in Item IV. These results are listed in Tables 14 and 15. Data was also obtained behind each of the mockups with the bare detector located at $30 \mathrm{~cm}$ inside a $\mathrm{Cd}$ hut and at 30 and $150 \mathrm{~cm}$ with $\mathrm{Cd}$ over the face of the shield mockup. These data are given in Tables 21 and 22 . Foil activation measurements were not obtained in this series.

\subsection{IHX MOCKUP (SODIUM WITH SODIUM SIDE SLABS) (ITEMS VA-E)}

For the remainder of the mockups in this experiment, the spectrum modifier was changed from the combination of $\mathrm{Fe}, \mathrm{Al}$, boral, and $\mathrm{Na}$ to just large cylindrical sodium tanks as seen in Figure 4 and discussed earlier in section 4.1. The shield mockups that followed this SM were no longer composed of just those slabs placed perpendicular to the beam centerline as in the previous mockups, but they also included the sodium and $\mathrm{B}_{4} \mathrm{C}$ slabs that were placed parallel to the beam centerline at the sides of the other slabs. 
Concrete blocks were placed radially beyond these side tanks to support the concrete slabs that would be placed above the mockup. PNC had requested in the original program plan that two sodium tanks be placed on each side of the central sodium tanks. The use of two tanks at each side would have pushed the location of the concrete support blocks beyond the distance that could be spanned by the concrete slabs available at the TSF to cover the mockup. To correct this problem it was necessary to limit the sodium side tanks to just one on each side.

The IHX sodium in this mockup was represented by a maximum of four $155-\mathrm{cm}-$ wide sodium tanks spaced to provide small voids between the tanks for placement of $\mathrm{Na}_{2} \mathrm{CO}_{3}$ capsules. This arrangement and the location of the foils within the voids is shown in Figure 11. A schematic of the actual mockup is shown in Figure 18.

Measurements were made with the bare, Cd-covered, 3-, 5-, 8-, and 10-inch Bonner balls on centerline at 30 and $150 \mathrm{~cm}$ behind the spectrum modifier and each sodium slab as it was added to the mockup. These results are given in Tables 14 and 15 . Bare detector measurements were made at $30 \mathrm{~cm}$ in Items $\mathrm{D}$ and $\mathrm{E}$ with a small Cd sheet placed closely behind the detector so that it could see only the mockup and the side sodium tanks. The Cd was used in an attempt to eliminate background contributions. These results are placed in Table 21. Starting with this series of experiments, background measurements required placing the shadow shield closer to the detector so that the detector could not see the edges of the $\mathrm{B}_{4} \mathrm{C}$ and the sodium tanks residing at the sides of the mockup tanks since these side tanks are to be considered as part of the mockup through the remainder of the program. This limited background measurements to Items $\mathrm{C}, \mathrm{D}$, and $\mathrm{E}$ as indicated in the program plan.

$\mathrm{Na}_{2} \mathrm{CO}_{3}$ capsules were exposed in each of the voids listed in Figure 18. Six capsules were placed in each void in the pattern shown in Figure 11 and exposed for one hour at a nominal reactor power of one megawatt. For this exposure the greater depth of void number one was due to the absence of the $\mathrm{B}_{4} \mathrm{C}$ slab that will be inserted in the next series of mockups in Item VI, thus keeping the sodium tank locations the same for $\mathrm{Na}_{2} \mathrm{CO}_{3}$ capsule exposures in both $\mathrm{V}$ and VI. The values for the sodium activation at each of the voids is given in Table 23. 


\subsection{IHX MOCKUP (BORON CARBIDE FRONT SHIELD - SODIUM SIDE SLABS) (ITEMS VIA-E)}

For this series of mockups the $\mathrm{B}_{4} \mathrm{C}$ slab was placed in the void area in front of the sodium tanks while keeping the side shields the same as in Item V. Bare, Cd-covered, 3-, 5-, 8-, and 10-inch Bonner ball measurements were made on centerline at 30 and $150 \mathrm{~cm}$ behind the last slab in each mockup. These count rate values are part of Tables 14 and 15. Background measurements were made only behind mockups $\mathrm{C}, \mathrm{D}$, and $\mathrm{E}$, and these results are also in Table 15. Bare detector measurements were made with $\mathrm{Cd}$ behind it at $30 \mathrm{~cm}$ in $\mathrm{C}$ and $\mathrm{E}$ and the data is in Table 21.

Placement of the $\mathrm{B}_{4} \mathrm{C}$ slab in the mockup created another void (number 2) between it and the sodium slab that followed it as seen in Figure 19. $\mathrm{Na}_{2} \mathrm{CO}_{3}$ capsules were exposed in all six voids and the resulting activations are listed in Table 23.

\subsection{IHX MOCKUP (BORON CARBIDE FRONT SHIELD - PARTIAL SIDE SHIELD) (ITEMS VIIA-F)}

In this mockup the $\mathrm{B}_{4} \mathrm{C}$ slab and sodium slabs in the IHX region were retained, but the sodium slab on each side was moved radially to allow insertion of half slabs of $\mathrm{B}_{4} \mathrm{C}$ and aluminum next to the IHX slabs as seen in Figure 20. The bare, Cd-covered, 3-, 5-, 8-, and 10-inch Bonner ball measurements were made behind each of the IHX slabs as they were placed in the mockup. These results are located in Tables 14 and 15. Background measurements were limited to the thicker mockups, D, E, and F, at $150 \mathrm{~cm}$ only and these values are also in Table 15. A sheet of $\mathrm{Cd}$ was placed behind the bare detector at $30 \mathrm{~cm}$ in Items D, E, and F, and these results are contained in Table 21. Results from similar measurements at $150 \mathrm{~cm}$ for each mockup are given in Table 22 . Background data were obtained with the same detector when a $\mathrm{Cd}$ sheet was placed over the back face (face closest to the detector) of the shadow shield and these data are also in Table 22.

A new measurement was added to the data plan for the mockups in Items $\mathrm{A}$ and B. Data was obtained with the bare detector at 30 and $150 \mathrm{~cm}$ when $\mathrm{Cd}$ was placed above the detector but below the concrete slabs covering the mockup area to eliminate the thermal neutron contribution leaving the concrete slab and reaching the detector. The results of these measurements are shown in Tables 21 and 22. A bare detector measurement was repeated at $150 \mathrm{~cm}$ with $\mathrm{Cd}$ both behind it and also above it as in the 
previous measurement and this result is in Table 22.

$\mathrm{Na}_{2} \mathrm{CO}_{3}$ foils were not exposed in void number 2 in this mockup because in the previous run, Item VI, it was necessary for personnel to be exposed to a high radiation field for an extended time to retrieve the foils from that void. The results of the measurements in the other five voids are given in Table 23.

\subsection{IHX MOCKUP BORON CARBIDE FRONT SHIELD - BORON CARBIDE SIDE SHIELD) (ITEMS VIIA-F)}

A schematic of the slab arrangements in this mockup is given in Figure 21. The $\mathrm{B}_{4} \mathrm{C}$ slab and four sodium slabs are enclosed on each side by a thin slab of $\mathrm{B}_{4} \mathrm{C}$ followed by a slab of sodium, lithiated paraffin, and concrete. Measurements were made with the bare, Cd-covered, 3-, 5-, 8-, and 10-inch Bonner balls on centerline at 30 and $150 \mathrm{~cm}$ behind each slab as they were added to the mockup. These results are given in Tables 14 and 15 respectively. Again there were no background measurements in the first three mockups, Items A through C. For Items C, D, and F, measurements were obtained at 150 $\mathrm{cm}$ with $\mathrm{Cd}$ behind the bare detector. Similar measurements were made with the bare detector at $30 \mathrm{~cm}$ and $\mathrm{Cd}$ behind it in Items D, E, and F. A background measurement with the bare detector was included in Item $\mathrm{F}$ with $\mathrm{Cd}$ over the back face of the shadow shield. These extra data are in Tables 21 and 22.

Capsules of $\mathrm{Na}_{2} \mathrm{CO}_{3}$ were exposed in all voids except number 2 as in previous item and these activity values can be found in Table 23 .

\subsection{IHX MOCKUP (BORON CARBIDE FRONT SHIELD WITH ALUMINUM WINDOW - BORON CARBIDE SIDE SHIELD) (ITEMS IXA-E)}

In this series of mockups the front $\mathrm{B}_{4} \mathrm{C}$ slab in the previous mockup was replaced with one containing a 14.96-cm-diameter aluminum cylinder (see Figure 9) that represented the sodium entry pipe into the IHX vessel. Locations of this slab and sodium cylinder are shown in the schematic in Figure 22.

Results from the limited number of measurements in the previous Items $\mathrm{V}$ through VIII indicated that it might be helpful in doing the analysis if further studies were made in an attempt to define the neutron source areas within the mockup from which neutrons emerge and strike the detector. The mockup for Item IXA was selected as indicated in the program plan. Measurements were made at 30 and $150 \mathrm{~cm}$ with the bare detector when $\mathrm{Cd}$ was placed at different locations within the mockup and these results can be 
found in Tables 21 and 22.

The first measurement was obtained at $150 \mathrm{~cm}$ with a piece of $\mathrm{Cd}$ behind the bare detector to discriminate against background neutrons. That piece of $\mathrm{Cd}$ was removed and the face of the lithiated paraffin above the front $\mathrm{B}_{4} \mathrm{C}$ slab $(6 \mathrm{~W})$ was covered with $\mathrm{Cd}$. To that configuration was then added a sheet of $\mathrm{Cd}$ above the detectors but beneath the concrete slab. The Cd above the detectors was removed in the next measurement and the face of the lithiated paraffin bricks above the side $\mathrm{B}_{4} \mathrm{C}$ slabs $(7 \mathrm{~W}$ and $8 \mathrm{~W}$ ) was covered with $\mathrm{Cd}$ along with the bricks above the front $\mathrm{B}_{4} \mathrm{C}$ slab. A piece of $\mathrm{Cd}$ was added over the aluminum insert in the front $\mathrm{B}_{4} \mathrm{C}$ slab in addition to the previous $\mathrm{Cd}$ locations. In the next run the $\mathrm{Cd}$ was kept the same and a $\mathrm{Cd}$ sheet was placed again above the detectors. Then without changing any of the $\mathrm{Cd}, 10.2 \mathrm{~cm}$ of lithiated paraffin was placed behind the front $\mathrm{B}_{4} \mathrm{C}$ slab and this time measurements were made using both the bare and $\mathrm{Cd}$ covered detectors.

As in the previous mockups a series of bare, Cd-covered, 3-, 5-, 8-, and 10-in Bonner ball measurements were made on centerline at 30 and $150 \mathrm{~cm}$ behind each of the slabs as they were added to the mockup. These results are contained in Tables 14 and 15. As noted in the program plan, measurements were made with the bare detector when $\mathrm{Cd}$ was placed at several locations for the other mockups also. In Items B and C, data were obtained with the $\mathrm{Cd}$ piece behind the detector and with a $\mathrm{Cd}$ sheet above the detector. Measurements were made in Items $\mathrm{D}$ and $\mathrm{E}$ when a $\mathrm{Cd}$ piece was placed behind the detector at both 30 and $150 \mathrm{~cm}$ and at $150 \mathrm{~cm}$ when the face of the shadow shield was covered with $\mathrm{Cd}$. Results from these measurements are in Tables 21 and 22 also.

$\mathrm{Na}_{2} \mathrm{CO}_{3}$ capsules were exposed in just the five voids (number 2 omitted) and the resulting activations are listed in Table 23.

\subsection{IHX MOCKUP WITH SOLID BORON CARBIDE/ALUMINUM FRONT SHIELD AND FULL BORON CARBIDE SIDE SHIELDS (Items XA-E)}

A schematic for the last mockup is shown in Figure 23. The front slab in the mockup was a combination of one half $\mathrm{B}_{4} \mathrm{C}$ and one half aluminum joined at the beam centerline. These are the same slabs used in Item VII that combined to form the two partial side shields. In this mockup the side shields were the two $\mathrm{B}_{4} \mathrm{C}$ slabs ( $7 \mathrm{~W}$ and $8 \mathrm{~W}$ ), each followed by a slab of sodium. The bare, Cd-covered, 3-, 5-, 8-, and 10-in Bonner ball data obtained on centerline at 30 and $150 \mathrm{~cm}$ behind each slab as they were added to the 
mockup are given in Tables 14 and 15. As in the previous items, the measurements made with the bare detector when $\mathrm{Cd}$ was placed behind the detector, above it, or over the face of the shadow shield are found in Tables 21 and 22.

Throughout the experiment little attention was paid to the contribution from neutrons being reflected from the floor of the mockup. The floor, described earlier, consisted of $20.3 \mathrm{~cm}$ of lithiated paraffin followed by concrete. One run in Item B was made with a bare detector at 30 and $150 \mathrm{~cm}$ when $\mathrm{Cd}$ was placed above and on the floor below the detector and these data are also in Tables 21 and 22. The effect of the Cd on the floor can be estimated when comparing this data with that in Item B where Cd was above the detector only.

It was possible to expose $\mathrm{Na}_{2} \mathrm{CO}_{3}$ capsules in all six voids in this mockup and the resultant activations for each of the capsules are listed in Table 23.

Another special measurement was included to aid in the analysis of the experiment. Radial traverses were made at $30 \mathrm{~cm}$ behind the mockup as measured on centerline. The mockup was the same one shown in Figure 23, but the schematic in Figure 24 relates the distances behind various slabs as the detector travels radially. Data were obtained to the left of centerline for the bare and Cd-covered Bonner balls, while full traverses were obtained with the 3-, 5-, and 10-in balls. All the data are reported in Table 24. 


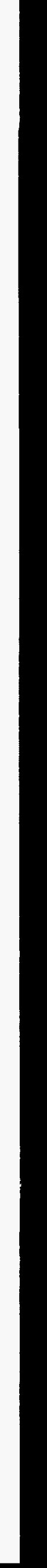




\section{ANALYSIS OF EXPERIMENTAL ERRORS}

The errors associated with the measurements are due to a number of uncertainties: (1) the sizes of the gaps between slabs, unavoidably introduced in the configurations, (2) the positions of the detectors, (3) the detector count rate statistics and calibrations, (4) the reactor power determinations, and (5) the effects of the exposure of the configurations to the weather. Of these, the uncertainty due to the weather is the least understood and probably beyond simple estimation. The uncertainty lies in the amount of moisture between the slabs and in the lithiated paraffin surrounding them. During this experiment the mockups were covered with a plastic tarpaulin that would limit the amount of moisture reaching the slabs. Thus, for this experiment, the effect of the weather was assumed to be negligible.

The TSR-II power level for each measurement was determined from the output of two fission chambers located in the reactor shield along the midplane of the reactor. The response of these chambers to the reactor source was monitored prior to the experiment through the use of gold foils and this ratio, detector response to gold foil results, agreed within about $5 \%$ with a history of earlier such comparisons. These detectors were calibrated on a daily basis using a ${ }^{252} \mathrm{Cf}$ source, with the calibration values lying within about a $6 \%$ spread $( \pm 3 \%$ of an average value). During any one detector traverse in a given day, the variation in the reactor power indicated by the monitor outputs was at most only $3 \%$; however, during the several months the experiment was being performed, the monitors indicated a spread in any one power level of about $\pm 5 \%$. Thus, the uncertainty in the reactor power determination was assumed to be $\pm 5 \%$.

Count-rate statistics are expressed in a manner specific to each detector. For the NE-213 measurements, counting statistics and unfolding errors are included in the unfolding of the pulse-height spectra using the FERD code, with the resulting flux expressed in terms of lower and upper limits that represent a $68 \%$ confidence interval. Similar errors are expressed in the tabular data for the hydrogen measurements unfolded using SPEC4. Neither of the spectra, NE-213 or hydrogen counter, reflects the error in determining the reactor power since this error is not included in the unfolding program. This, as seen above, could be as much as ${ }_{ \pm} 5 \%$.

The Bonner balls were calibrated on a daily basis using ${ }^{252} \mathrm{Cf}$ as a source, with the resulting count rates falling within about $\pm 3 \%$ of an average value obtained throughout 
the years. Movement of the Bonner balls along a traversing mechanism can vary the detector location with respect to the configuration several millimeters on either side of a straight line. For the measurements perpendicular to the configuration centerline at 30 $\mathrm{cm}$ behind the configuration, such variations in the detector position could amount to a change in the count rate of about $2 \%$. For the measurements on centerline beyond the $30 \mathrm{~cm}$ point, the error in positioning several millimeters either side of the selected location would lie within the statistics of the measurement. Rather than calculate probable errors for each measurement in a series of measurements during a traverse, we prefer, in general, to quote a value for the error in the measurements for a given experiment. Thus, assuming the estimated upper limit for all the errors, the errors assigned to the Bonner ball measurements should be less than $\pm 10 \%$.

An overall absolute counting uncertainty of ${ }_{t} 5 \%$ was assigned to the sodium activity which included the geometry corrections in counting the capsules that had a large length-to-diameter ratio (L/D) and were placed in close proximity of the detector. This error does not include positioning of the capsules during exposure, nor does it account for the error in reactor power determination. Estimation of error in placement of the samples within the voids is hardly feasible since only one run was made for each mockup and each mockup was different. Error in the reactor power was assumed to be the same as quoted earlier, $\pm 5 \%$. Assigning an error of $\pm 10 \%$ in foil activity due to placements of the foils, the overall estimated error would lie between $\pm 10-15 \%$. 


\section{ACKNOWLEDGEMENTS}

The authors are deeply indebted to D. T. Ingersoll and J. V. Pace, III, of ORNL's Engineering Physics and Mathematics Division, to P. B. Hemmig of DOE/Washington, and to the JASPER working group from Japan for their participation and assistance in formulating the Experimental Program Plan. A deep gratitude is expressed to the TSR-II operating crew of the Research Reactors Division and TSF assigned members of the Instrumentation and Controls Division for not only maintaining a viable source but for experimental help when needed. The willingness of J. K. Dickens to interrupt his busy schedule to count the $\mathrm{Na}_{2} \mathrm{CO}_{3}$ foils warrants our special thanks. Appreciation is expressed to E. R. Specht, Rockwell International, W. H. Harless, General Electric Company, R. K. Disney, Westinghouse-ARD, W. L. Bunch, Westinghouse-Hanford for timely suggestions. Special thanks go to G. A. Marvin and S. A. Raby for their efforts in editing and preparing this report.

\section{REFERENCES}

1. R.E. Maerker et al., Calibration of the Bonner Ball Neutron Detectors Used at the Tower Shielding Facility, ORNL/TM-3465 (June 1971).

2. C. E. Burgart and M. B. Emmett, Monte Carlo Calculations of the Response Functions of Bonner Ball Neutron Detectors, ORNL/TM-3739 (April 1972).

3. B. W. Rust, D. T. Ingersoll, and W. R. Burrus, A User's Manual for the FERDO and FERD Unfolding Codes, ORNL/TM-8720 (September 1983).

4. J. O. Johnson and D. T. Ingersoll, User's Guide for the Revised SPEC-4 Neutron Spectrum Unfolding Code, ORNL/TM-7384 (August 1980).

5. J. K. Dickens and S. Raman, Fission-Product Yield Data from the US/UK Joint Experiment in the Dounreay Prototype Fast Reactor, ORNL-6266 (1986). 


\section{APPENDIX A}

\section{EXPERIMENTAL PROGRAM PLAN FOR THE JASPER INTERMEDIATE HEAT EXCHANGER (IHX) EXPERIMENT}

I. Spectrum Modifier

A. $\quad \mathrm{SM}-2(10 \mathrm{~cm} \mathrm{Fe}+9 \mathrm{~cm} \mathrm{Al}+2.54 \mathrm{~cm}$ boral $+180 \mathrm{~cm} \mathrm{Na})$

1. bare, Cd-covered, 3-, 5-, 8-, and 10-in Bonner ball measurements on centerline:

a. at $30 \mathrm{~cm}$ behind shield mockup

b. at $150 \mathrm{~cm}$ behind shield mockup (foreground and background)

2. Expose $\mathrm{Na}_{2} \mathrm{CO}_{3}$ capsules on centerline and at points where vertical and horizontal lines through center and $45.7 \mathrm{~cm}$ from center intersect behind the last Na slab.

AA. SM-2 $[10 \mathrm{~cm} \mathrm{Fe}+9 \mathrm{~cm} \mathrm{Al}+2.54 \mathrm{~cm}$ boral $+180 \mathrm{~cm} \mathrm{Na}$ (include voids) $]$

1. Between selected $\mathrm{Na}$ slabs, expose $\mathrm{Na}_{2} \mathrm{CO}_{3}$ capsules on centerline and at points where vertical and horizontal lines through center and $45.7 \mathrm{~cm}$ from center intersect.

2. Bare Bonner ball measurements on centerline:

a. at $30 \mathrm{~cm}$ inside $\mathrm{Cd}$ hut

b. $\quad$ at $30 \mathrm{~cm}$, with $\mathrm{Cd}$ over face of shield mockup

c. at $150 \mathrm{~cm}$, with $\mathrm{Cd}$ over face of shield mockup

B. $\quad$ SM-3 $(76.2 \mathrm{~cm} \mathrm{Na}+152.4 \mathrm{~cm} \mathrm{Na})$

1. NE 213 and hydrogen counters measurements on centerline as close as feasible behind the shield mockup

2. 3-, 5-, and 10-in Bonner ball measurements at location of NE 213 on centerline:

3. Bare, Cd-covered, 3-, 5-, 8-, and 10-in Bonner ball measurements on centerline:

a. at $30 \mathrm{~cm}$ behind shield mockup

b. at $150 \mathrm{~cm}$ behind shield mockup (foreground and background)

4. 5-in Bonner ball traverse at $30 \mathrm{~cm}$ behind shield mockup

5. Expose $\mathrm{Na}_{2} \mathrm{CO}_{3}$, bare and $\mathrm{Cd}$-covered, on centerline between the two sodium tanks

II. ALMR (below spent fuels)

A. $\quad \mathrm{SM}-2+3.81 \mathrm{~cm} \mathrm{SS}+3.29 \mathrm{~cm} \mathrm{Al}+5.62 \mathrm{~cm} \mathrm{~B} \mathrm{C}_{4}+1.27 \mathrm{~cm} \mathrm{Al}$

1. Bare, Cd-covered, 3-, 5-, 8-, and 10-in Bonner ball measurements on centerline:

a. at $30 \mathrm{~cm}$ behind shield mockup

b. at $150 \mathrm{~cm}$ behind shield mockup (foreground and background) 
B. $\quad \mathrm{SM}-2+3.81 \mathrm{~cm} \mathrm{SS}+3.29 \mathrm{~cm} \mathrm{Al}+5.62 \mathrm{~cm} \mathrm{~B} 4 \mathrm{C}+1.27 \mathrm{~cm} \mathrm{Al}+$ $5.08 \mathrm{~cm} \mathrm{SS}+3.81 \mathrm{~cm} \mathrm{Al}+15.61 \mathrm{~cm} \mathrm{~B}_{4} \mathrm{C}+2.54 \mathrm{~cm} \mathrm{Al}$

1. Bare, Cd-covered, 3-, 5-, 8-, and 10-in Bonner ball measurements on centerline:

a. at $30 \mathrm{~cm}$ behind shield mockup

b. at $150 \mathrm{~cm}$ behind shield mockup (foreground and background)

C. $\quad \mathrm{SM}-2+3.81 \mathrm{~cm} \mathrm{SS}+3.29 \mathrm{~cm} \mathrm{Al}+5.62 \mathrm{~cm} \mathrm{~B} 4 \mathrm{C}+1.27 \mathrm{~cm} \mathrm{Al}+$ $5.08 \mathrm{~cm} \mathrm{SS}+3.81 \mathrm{~cm} \mathrm{Al}+15.61 \mathrm{~cm} \mathrm{~B}_{4} \mathrm{C}+2.54 \mathrm{~cm} \mathrm{Al}+30.48 \mathrm{~cm} \mathrm{Na}$

1. Bare, Cd-covered, 3-, 5-, 8-, and 10-in Bonner ball measurements on centerline:

a. at $30 \mathrm{~cm}$ behind shield mockup

b. at $150 \mathrm{~cm}$ behind shield mockup (foreground and background)

D. $\quad \mathrm{SM}-2+3.81 \mathrm{~cm} \mathrm{SS}+3.29 \mathrm{~cm} \mathrm{Al}+5.62 \mathrm{~cm} \mathrm{~B} 4 \mathrm{C}+1.27 \mathrm{~cm} \mathrm{Al}+$ $5.08 \mathrm{~cm} \mathrm{SS}+3.81 \mathrm{~cm} \mathrm{Al}+15.61 \mathrm{~cm} \mathrm{~B}{ }_{4} \mathrm{C}+2.54 \mathrm{~cm} \mathrm{Al}+30.48 \mathrm{~cm} \mathrm{Na}+$ $30.48 \mathrm{~cm} \mathrm{Na}$

1. Bare, Cd-covered, 3-, 5-, 8-, and 10-in Bonner ball measurements on centerline:
a. at $30 \mathrm{~cm}$ behind shield mockup
b. at $150 \mathrm{~cm}$ behind shield mockup (foreground and background)

2. Bare Bonner ball measurements on centerline:
a. at $30 \mathrm{~cm}$ inside $\mathrm{Cd}$ hut
b. at $30 \mathrm{~cm}$, with Cd over face of shield mockup
c. at $150 \mathrm{~cm}$, with $\mathrm{Cd}$ over face of shield mockup

E. $\quad \mathrm{SM}-2+3.81 \mathrm{~cm} \mathrm{SS}+3.29 \mathrm{~cm} \mathrm{Al}+5.62 \mathrm{~cm} \mathrm{~B} \mathrm{C}_{4}+1.27 \mathrm{~cm} \mathrm{Al}+$ $5.08 \mathrm{~cm} \mathrm{SS}+3.81 \mathrm{~cm} \mathrm{Al}+15.61 \mathrm{~cm} \mathrm{~B}{ }_{4} \mathrm{C}+2.54 \mathrm{~cm} \mathrm{Al}+30.48 \mathrm{~cm} \mathrm{Na}+$ $30.48 \mathrm{~cm} \mathrm{Na}+30.48 \mathrm{~cm} \mathrm{Na}$

1. Bare, Cd-covered, 3-, 5-, 8-, and 10-in Bonner ball measurements on centerline:

a. at $30 \mathrm{~cm}$ behind shield mockup

b. at $150 \mathrm{~cm}$ behind shield mockup (foreground and background)

2. Bare Bonner ball measurements on centerline:
a. at $30 \mathrm{~cm}$ inside $\mathrm{Cd}$ hut
b. at $30 \mathrm{~cm}$, with $\mathrm{Cd}$ over face of shield mockup
c. at $150 \mathrm{~cm}$, with $\mathrm{Cd}$ over face of shield mockup 
F.

$\mathrm{SM}-2+3.81 \mathrm{~cm} \mathrm{SS}+3.29 \mathrm{~cm} \mathrm{Al}+5.62 \mathrm{~cm} \mathrm{~B}$ C $+1.27 \mathrm{~cm} \mathrm{Al}+$ $5.08 \mathrm{~cm} \mathrm{SS}+3.81 \mathrm{~cm} \mathrm{Al}+15.61 \mathrm{~cm} \mathrm{~B} 4 \mathrm{C}+2.54 \mathrm{~cm} \mathrm{Al}+30.48$ $\mathrm{cm} \mathrm{Na}+30.48 \mathrm{~cm} \mathrm{Na}+30.48 \mathrm{~cm} \mathrm{Na}+30.48 \mathrm{~cm} \mathrm{Na}$

1. Bare, Cd-covered, 3-, 5-, 8-, and 10-in Bonner ball measurements on centerline:

a. at $30 \mathrm{~cm}$ behind shield mockup

b. at $150 \mathrm{~cm}$ behind shield mockup (foreground and background)

2. Bare Bonner ball measurements on centerline:

a. at $30 \mathrm{~cm}$ inside $\mathrm{Cd}$ hut

b. $\quad$ at $30 \mathrm{~cm}$, with $\mathrm{Cd}$ over face of shield mockup

c. at $150 \mathrm{~cm}$, with $\mathrm{Cd}$ over face of shield mockup

III. ALMR (fuel region of spent fuel)

A. SM-2 $+16.04 \mathrm{~cm}$ IVFS (homogeneous) vessel (thin slab of fuel pins)

1. Bare, Cd-covered, 3-, 5-, 8-, and 10-in Bonner ball measurements on centerline:
a. at $30 \mathrm{~cm}$ behind shield mockup
b. at $150 \mathrm{~cm}$ behind shield mockup (foreground and background)

2. Bare Bonner ball measurements on centerline:

a. at $30 \mathrm{~cm}$ inside $\mathrm{Cd}$ hut

B. SM-2 $+16.04 \mathrm{~cm}$ IVFS (homogeneous) vessel (thin slab of fuel pins) + $5.15 \mathrm{~cm} \mathrm{~B} 4 \mathrm{C}+5.08 \mathrm{~cm} \mathrm{SS}$

1. Bare, Cd-covered, 3-, 5-, 8-, and 10-in Bonner ball measurements on centerline:
a. at $30 \mathrm{~cm}$ behind shield mockup
b. at $150 \mathrm{~cm}$ behind shield mockup (foreground and background)

C. SM-2 $+16.04 \mathrm{~cm}$ IVFS (homogeneous) vessel (thin slab of fuel pins) + $5.15 \mathrm{~cm} \mathrm{~B} 4 \mathrm{C}+5.08 \mathrm{~cm} \mathrm{SS}+15.61 \mathrm{~cm} \mathrm{~B}_{4} \mathrm{C}$

1. Bare, Cd-covered, 3-, 5-, 8-, and 10-in Bonner ball measurements on centerline:
a. at $30 \mathrm{~cm}$ behind shield mockup
b. at $150 \mathrm{~cm}$ behind shield mockup (foreground and background)

2. Bare Bonner ball measurements on centerline:
a. at $30 \mathrm{~cm}$ inside $\mathrm{Cd}$ hut

D. SM-2 $+16.04 \mathrm{~cm}$ IVFS (homogeneous) vessel (thin slab of fuel pins) + $5.15 \mathrm{~cm} \mathrm{~B} 4 \mathrm{C}+5.08 \mathrm{~cm} \mathrm{SS}+15.61 \mathrm{~cm} \mathrm{~B}_{4} \mathrm{C}+30.48 \mathrm{~cm} \mathrm{Na}+2.54 \mathrm{~cm} \mathrm{SS}$

1. Bare, Cd-covered, 3-, 5-, 8-, and 10-in Bonner ball measurements on centerline:
a. at $30 \mathrm{~cm}$ behind shield mockup
b. at $150 \mathrm{~cm}$ behind shield mockup (foreground and background)

2. Bare Bonner ball measurements on centerline:

a. at $30 \mathrm{~cm}$ inside $\mathrm{Cd}$ hut 
E. SM-2 $+16.04 \mathrm{~cm}$ IVFS (homogeneous) vessel (thin slab of fuel pins) + $5.15 \mathrm{~cm} \mathrm{~B}{ }_{4} \mathrm{C}+5.08 \mathrm{~cm} \mathrm{SS}+15.61 \mathrm{~cm} \mathrm{~B}_{4} \mathrm{C}+30.48 \mathrm{~cm} \mathrm{Na}+2.54 \mathrm{~cm} \mathrm{SS}$ $+30.48 \mathrm{~cm} \mathrm{Na}$

1. Bare, Cd-covered, 3-, 5-, 8-, and 10-in Bonner ball measurements on centerline:

a. at $30 \mathrm{~cm}$ behind shield mockup

b. at $150 \mathrm{~cm}$ behind shield mockup (foreground and background)

2. Bare Bonner ball measurements on centerline:

a. at $30 \mathrm{~cm}$ inside $\mathrm{Cd}$ hut

IV. ALMR (fission gas plenum region of spent fuel)

A. $\quad$ SM-2 + empty $16.04 \mathrm{~cm}$ IVFS (homogeneous) vessel (no fuel) +

$2.54 \mathrm{~cm} \mathrm{Al}+5.15 \mathrm{~cm} \mathrm{~B}_{4} \mathrm{C}$

1. Bare, Cd-covered, 3-, 5-, 8-, and 10-in Bonner ball measurements on centerline:
a. at $30 \mathrm{~cm}$ behind shield mockup
b. at $150 \mathrm{~cm}$ behind shield mockup (foreground and background)

2. Bare Bonner ball measurements on centerline:
a. at $30 \mathrm{~cm}$ inside $\mathrm{Cd}$ hut
b. at $30 \mathrm{~cm}$, with $\mathrm{Cd}$ over face of shield mockup
c. at $150 \mathrm{~cm}$, with $\mathrm{Cd}$ over face of shield mockup

B. SM-2 + empty $16.04 \mathrm{~cm}$ IVFS (homogeneous) vessel (no fuel) + $2.54 \mathrm{~cm} \mathrm{Al}+5.15 \mathrm{~cm} \mathrm{~B} 4 \mathrm{C}+5.08 \mathrm{~cm} \mathrm{SS}+30.48 \mathrm{~cm} \mathrm{Na}+2.54 \mathrm{~cm} \mathrm{SS}$

1. . Bare, Cd-covered, 3-, 5-, 8-, and 10-in Bonner ball measurements on centerline:
a. at $30 \mathrm{~cm}$ behind shield mockup
b. at $150 \mathrm{~cm}$ behind shield mockup (foreground and background)

2. Bare Bonner ball measurements on centerline:
a. at $30 \mathrm{~cm}$ inside $\mathrm{Cd}$ hut
b. at $30 \mathrm{~cm}$, with $\mathrm{Cd}$ over face of shield mockup
c. at $150 \mathrm{~cm}$, with Cd over face of shield mockup

C. SM-2 + empty $16.04 \mathrm{~cm}$ IVFS (homogeneous) vessel (no fuel) + $2.54 \mathrm{~cm} \mathrm{Al}+5.15 \mathrm{~cm} \mathrm{~B}_{4} \mathrm{C}+5.08 \mathrm{~cm} \mathrm{SS}+30.48 \mathrm{~cm} \mathrm{Na}+2.54 \mathrm{~cm} \mathrm{SS}+$ $30.48 \mathrm{~cm} \mathrm{Na}$

1. Bare, Cd-covered, 3-, 5-, 8-, and 10-in Bonner ball measurements on centerline:
a. at $30 \mathrm{~cm}$ behind shield mockup
b. at $150 \mathrm{~cm}$ behind shield mockup (foreground and background)

2. Bare Bonner ball measurements on centerline:
a. at $30 \mathrm{~cm}$ inside $\mathrm{Cd}$ hut
b. at $30 \mathrm{~cm}$, with $\mathrm{Cd}$ over face of shield mockup
c. at $150 \mathrm{~cm}$, with $\mathrm{Cd}$ over face of shield mockup 
D. SM-2 + empty $16.04 \mathrm{~cm}$ IVFS (homogeneous) vessel (no fuel) + $2.54 \mathrm{~cm} \mathrm{Al}+5.15 \mathrm{~cm} \mathrm{~B}$ C $+5.08 \mathrm{~cm} \mathrm{SS}+30.48 \mathrm{~cm} \mathrm{Na}+2.54 \mathrm{~cm} \mathrm{SS}+$ $30.48 \mathrm{~cm} \mathrm{Na}+30.48 \mathrm{~cm} \mathrm{Na}$

1. Bare, Cd-covered, 3-, 5-, 8-, and 10-in Bonner ball measurements on centerline:

a. at $30 \mathrm{~cm}$ behind shield mockup

b. at $150 \mathrm{~cm}$ behind shield mockup (foreground and background)

2. Bare Bonner ball measurements on centerline:

a. at $30 \mathrm{~cm}$ inside $\mathrm{Cd}$ hut

b. at $30 \mathrm{~cm}$, with $\mathrm{Cd}$ over face of shield mockup

c. at $150 \mathrm{~cm}$, with $\mathrm{Cd}$ over face of shield mockup

E. SM-2 + empty $16.04 \mathrm{~cm}$ IVFS (homogeneous) vessel (no fuel) + $2.54 \mathrm{~cm} \mathrm{Al}+5.15 \mathrm{~cm} \mathrm{~B}$ C $+5.08 \mathrm{~cm} \mathrm{SS}+30.48 \mathrm{~cm} \mathrm{Na}+2.54 \mathrm{~cm} \mathrm{SS}+$ $30.48 \mathrm{~cm} \mathrm{Na}+30.48 \mathrm{~cm} \mathrm{Na}+2.54 \mathrm{~cm} \mathrm{SS}+30.48 \mathrm{~cm} \mathrm{Na}$

1. Bare, Cd-covered, 3-, 5-, 8-, and 10-in Bonner ball measurements on centerline:

a. at $30 \mathrm{~cm}$ behind shield mockup

b. at $150 \mathrm{~cm}$ behind shield mockup (foreground and background)

2. Bare Bonner ball measurements on centerline:

a. at $30 \mathrm{~cm}$ inside $\mathrm{Cd}$ hut

b. $\quad$ at $30 \mathrm{~cm}$, with $\mathrm{Cd}$ over face of shield mockup

c. at $150 \mathrm{~cm}$, with $\mathrm{Cd}$ over face of shield mockup

V. IHX Mockup (Na Shield - Na Side Shield)

A. SM-3 only

1. Bare, Cd-covered, 3-, 5-, 8-, and 10-in Bonner ball measurements on centerline:

a. at $30 \mathrm{~cm}$ behind shield mockup

b. at $150 \mathrm{~cm}$ behind shield mockup (foreground only)

B. $\quad \mathrm{SM}-3+30.48 \mathrm{~cm} \mathrm{Na}$

1. Bare, Cd-covered, 3-, 5-, 8-, and 10-in Bonner ball measurements on centerline:

a. at $30 \mathrm{~cm}$ behind shield mockup

b. at $150 \mathrm{~cm}$ behind shield mockup (foreground only)

C. $\quad \mathrm{SM}-3+61 \mathrm{~cm} \mathrm{Na}$

1. Bare, Cd-covered, 3-, 5-, 8-, and 10-in Bonner ball measurements on centerline:

a. at $30 \mathrm{~cm}$ behind shield mockup

b. at $150 \mathrm{~cm}$ behind shield mockup (foreground and background) 
D. $\quad \mathrm{SM}-3+91 \mathrm{~cm} \mathrm{Na}$

1. Bare, Cd-covered, 3-, 5-, 8-, and 10-in Bonner ball measurements on centerline:
a. at $30 \mathrm{~cm}$ behind shield mockup
b. at $150 \mathrm{~cm}$ behind shield mockup (foreground and background)

2. Bare Bonner ball measurements on centerline:

E. $\quad \mathrm{SM}-3+122 \mathrm{~cm} \mathrm{Na}$
a. at $30 \mathrm{~cm}$, with $\mathrm{Cd}$ sheet behind detector

1. Bare, Cd-covered, 3-, 5-, 8-, and 10-in Bonner ball measurements on centerline:
a. at $30 \mathrm{~cm}$ behind shield mockup
b. at $150 \mathrm{~cm}$ behind shield mockup (foreground and background)

2. Bare Bonner ball measurements on centerline:

a. at $30 \mathrm{~cm}$, with $\mathrm{Cd}$ sheet behind detector

3. Expose $\mathrm{Na}_{2} \mathrm{CO}_{3}$ capsules between mockup slabs on the horizontal centerline and on a parallel line $45.7 \mathrm{~cm}$ above the horizontal centerline

\section{IHX Mockup ( $B_{4} C$ Front Shield - $\mathrm{Na}$ Side Shields)}

\section{A. $\quad \mathrm{SM}-3+13.05 \mathrm{~cm} \mathrm{~B} 4 \mathrm{C}$}

1. Bare, Cd-covered, 3-, 5-, 8-, and 10-in Bonner ball measurements on centerline:

a. at $30 \mathrm{~cm}$ behind shield mockup

b. at $150 \mathrm{~cm}$ behind shield mockup (foreground only)

B. $\quad \mathrm{SM}-3+13.05 \mathrm{~cm} \mathrm{~B} \mathrm{C}_{4}+30.48 \mathrm{~cm} \mathrm{Na}$

1. Bare, Cd-covered, 3-, 5-, 8-, and 10-in Bonner ball measurements on centerline:

a. at $30 \mathrm{~cm}$ behind shield mockup

b. at $150 \mathrm{~cm}$ behind shield mockup (foreground only)

C. $\quad \mathrm{SM}-3+13.05 \mathrm{~cm} \mathrm{~B}_{4} \mathrm{C}+61 \mathrm{~cm} \mathrm{Na}$

1. bare, cd-covered, 3-, 5-, 8-, and 10-in Bonner ball measurements on centerline:

a. at $30 \mathrm{~cm}$ behind shield mockup

b. at $150 \mathrm{~cm}$ behind shield mockup (foreground and background)

2. Bare Bonner ball measurements on centerline:

a. at $30 \mathrm{~cm}$, with $\mathrm{Cd}$ sheet behind detector

D. $\quad \mathrm{SM}-3+13.05 \mathrm{~cm} \mathrm{~B} 4 \mathrm{C}+91 \mathrm{~cm} \mathrm{Na}$

1. Bare, Cd-covered, 3-, 5-, 8-, and 10-in Bonner ball measurements on centerline:

a. at $30 \mathrm{~cm}$ behind shield mockup

b. at $150 \mathrm{~cm}$ behind shield mockup (foreground and background) 
E. $\quad \mathrm{SM}-3+13.05 \mathrm{~cm} \mathrm{~B} \mathrm{C}_{4}+122 \mathrm{~cm} \mathrm{Na}$

1. bare, cd-covered, 3-, 5-, 8-, and 10-in Bonner ball measurements on centerline:

a. at $30 \mathrm{~cm}$ behind shield mockup

b. at $150 \mathrm{~cm}$ behind shield mockup (foreground and background)

2. Bare Bonner ball measurements on centerline:

a. at $30 \mathrm{~cm}$, with $\mathrm{Cd}$ sheet behind detector

3. Expose $\mathrm{Na}_{2} \mathrm{CO}_{3}$ capsules between mockup slabs on the horizontal centerline and on a parallel line $45.7 \mathrm{~cm}$ above the horizontal centerline

VII. IHX Mockup (partial side shields)

A. SM-3 only

1. Bare, Cd-covered, 3-, 5-, 8-, and 10-in Bonner ball measurements on centerline:

a. at $30 \mathrm{~cm}$ behind shield mockup

b. at $150 \mathrm{~cm}$ behind shield mockup (foreground only)

2. Bare Bonner ball measurements on centerline:

a. at $150 \mathrm{~cm}$, with $\mathrm{Cd}$ sheet behind detector

B. $\quad \mathrm{SM}-3+13.05 \mathrm{~cm} \mathrm{~B} \mathrm{C}_{4}$

1. Bare, Cd-covered, 3-, 5-, 8-, and 10-in Bonner ball measurements on centerline:
a. at $30 \mathrm{~cm}$ behind shield mockup
b. at $150 \mathrm{~cm}$ behind shield mockup (foreground only)

2. Bare Bonner ball measurements on centerline:

a. at $150 \mathrm{~cm}$, with $\mathrm{Cd}$ sheet behind detector

C. $\quad \mathrm{SM}-3+13.05 \mathrm{~cm} \mathrm{~B} 4 \mathrm{C}+30.48 \mathrm{~cm} \mathrm{Na}$

1. Bare, Cd-covered, 3-, 5-, 8-, and 10-in Bonner ball measurements on centerline:

a. at $30 \mathrm{~cm}$ behind shield mockup

b. at $150 \mathrm{~cm}$ behind shield mockup (foreground only)

2. Bare Bonner ball measurements on centerline:
a. at $150 \mathrm{~cm}$, with $\mathrm{Cd}$ sheet behind detector

D. $\quad \mathrm{SM}-3+13.05 \mathrm{~cm} \mathrm{~B} \mathrm{C}_{4}+61 \mathrm{~cm} \mathrm{Na}$

1. Bare, Cd-covered, 3-, 5-, 8-, and 10-in Bonner ball measurements on centerline:
a. at $30 \mathrm{~cm}$ behind shield mockup
b. at $150 \mathrm{~cm}$ behind shield mockup (foreground and background)

2. Bare Bonner ball measurements on centerline:
a. at $30 \mathrm{~cm}$, with $\mathrm{Cd}$ sheet behind detector
b. at $150 \mathrm{~cm}$, with $\mathrm{Cd}$ sheet behind detector
c. at $150 \mathrm{~cm}, \mathrm{Cd}$ sheet over face of background shadow shield 
E. $\quad \mathrm{SM}-3+13.05 \mathrm{~cm} \mathrm{~B} 4 \mathrm{C}+91 \mathrm{~cm} \mathrm{Na}$

1. Bare, Cd-covered, 3-, 5-, 8-, and 10-in Bonner ball measurements on centerline:
a. at $30 \mathrm{~cm}$ behind shield mockup
b. at $150 \mathrm{~cm}$ behind shield mockup (foreground and background)

2. Bare Bonner ball measurements on centerline:
a. at $30 \mathrm{~cm}$, with $\mathrm{Cd}$ sheet behind detector
b. . at $150 \mathrm{~cm}$, with $\mathrm{Cd}$ sheet behind detector
c. at $150 \mathrm{~cm}, \mathrm{Cd}$ sheet over face of background shadow shield

F. $\quad \mathrm{SM}-3+13.05 \mathrm{~cm} \mathrm{~B}_{4} \mathrm{C}+122 \mathrm{~cm} \mathrm{Na}$

1. Bare, Cd-covered, 3-, 5-, 8-, and 10-in Bonner ball measurements on centerline:
a. at $30 \mathrm{~cm}$ behind shield mockup
b. at $150 \mathrm{~cm}$ behind shield mockup (foreground and background)

2. Bare Bonner ball measurements on centerline:
a. at $30 \mathrm{~cm}$, with $\mathrm{Cd}$ sheet behind detector
b. at $150 \mathrm{~cm}$, with $\mathrm{Cd}$ sheet behind detector
c. at $150 \mathrm{~cm}, \mathrm{Cd}$ sheet over face of background shadow shield

3. Expose $\mathrm{Na}_{2} \mathrm{CO}_{3}$ capsules between mockup slabs on the horizontal centerline and on a parallel line $45.7 \mathrm{~cm}$ above the horizontal centerline

VIII. IHX Mockup (full side shields)

A. SM-3 only

1. Bare, Cd-covered, 3-, 5-, 8-, and 10-in Bonner ball measurements on centerline:

a. at $30 \mathrm{~cm}$ behind shield mockup

b. at $150 \mathrm{~cm}$ behind shield mockup (foreground only)

B. $\quad \mathrm{SM}-3+13.05 \mathrm{~cm} \mathrm{~B} \mathrm{C}_{4}$

1. Bare, Cd-covered, 3-, 5-, 8-, and 10-in Bonner ball measurements on centerline:

a. at $30 \mathrm{~cm}$ behind shield mockup

b. at $150 \mathrm{~cm}$ behind shield mockup (foreground only)

C. $\quad \mathrm{SM}-3+13.05 \mathrm{~cm} \mathrm{~B} \mathrm{C}_{4}+30.48 \mathrm{~cm} \mathrm{Na}$

1. Bare, Cd-covered, 3-, 5-, 8-, and 10-in Bonner ball measurements on centerline:

a. at $30 \mathrm{~cm}$ behind shield mockup

b. at $150 \mathrm{~cm}$ behind shield mockup (foreground only)

2. Bare Bonner ball measurements on centerline:

a. at $150 \mathrm{~cm}$, with $\mathrm{Cd}$ sheet behind detector 
D. $\quad \mathrm{SM}-3+13.05 \mathrm{~cm} \mathrm{~B} \mathrm{~B}_{4} \mathrm{C}+61 \mathrm{~cm} \mathrm{Na}$

1. Bare, Cd-covered, 3-, 5-, 8-, and 10-in Bonner ball measurements on centerline:

a. $\quad$ at $30 \mathrm{~cm}$ behind shield mockup

b. at $150 \mathrm{~cm}$ behind shield mockup (foreground and background)

2. Bare Bonner ball measurements on centerline:

a. $\quad$ at $30 \mathrm{~cm}$, with $\mathrm{Cd}$ sheet behind detector

b. at $150 \mathrm{~cm}$, with $\mathrm{Cd}$ sheet behind detector

E. $\quad \mathrm{SM}-3+13.05 \mathrm{~cm} \mathrm{~B}_{4} \mathrm{C}+91 \mathrm{~cm} \mathrm{Na}$

1. Bare, Cd-covered, 3-, 5-, 8-, and 10-in Bonner ball measurements on centerline:

a. at $30 \mathrm{~cm}$ behind shield mockup

b. at $150 \mathrm{~cm}$ behind shield mockup (foreground and background)

2. Bare Bonner ball measurements on centerline:

a. at $30 \mathrm{~cm}$, with $\mathrm{Cd}$ sheet behind detector

b. at $150 \mathrm{~cm}, \mathrm{Cd}$ sheet over face of background shadow shield

F. $\quad \mathrm{SM}-3+13.05 \mathrm{~cm} \mathrm{~B}_{4} \mathrm{C}+122 \mathrm{~cm} \mathrm{Na}$

1. Bare, Cd-covered, 3-, 5-, 8-, and 10-in Bonner ball measurements on centerline:

a. at $30 \mathrm{~cm}$ behind shield mockup

b. at $150 \mathrm{~cm}$ behind shield mockup (foreground and background)

2. Bare Bonner ball measurements on centerline:

a. at $30 \mathrm{~cm}$, with $\mathrm{Cd}$ sheet behind detector

b. at $150 \mathrm{~cm}$, with $\mathrm{Cd}$ sheet behind detector

c. at $150 \mathrm{~cm}, \mathrm{Cd}$ sheet over face of background shadow shield

3. Expose $\mathrm{Na}_{2} \mathrm{CO}_{3}$ capsules between mockup slabs on the horizontal centerline and on a parallel line $45.7 \mathrm{~cm}$ above the horizontal centerline 
IX. IHX Mockup (window in front shield - full side shields)

A. $\quad \mathrm{SM}-3+13.05 \mathrm{~cm} \mathrm{~B}_{4} \mathrm{C}$ (with $\mathrm{Al}$ window)

1. Bare, Cd-covered, 3-, 5-, 8-, and 10-in Bonner ball measurements on centerline:

a. at $\quad 30 \mathrm{~cm}$ behind shield mockup

b. $\quad$ at $150 \mathrm{~cm}$ behind shield mockup (foreground only)

2. Bonner ball measurements on centerline (foreground only):

a. bare, at $150 \mathrm{~cm}, \mathrm{Cd}$ piece behind detector

b. bare, at 30 and $150 \mathrm{~cm}, \mathrm{Cd}$ over Li-Par face above front $\mathrm{B}_{4} \mathrm{C}$ slab

c. bare, at 30 and $150 \mathrm{~cm}, \mathrm{Cd}$ over Li-Par face above front $\mathrm{B}_{4} \mathrm{C}$ slab $+\mathrm{Cd}$ directly beneath concrete over detectors

d. bare, at 30 and $150 \mathrm{~cm}, \mathrm{Cd}$ over Li-Par face above both front and side $\mathrm{B}_{4} \mathrm{C}$ slabs

e. bare, at 30 and $150 \mathrm{~cm}, \mathrm{Cd}$ over Li-Par face above both front and side $\mathrm{B}_{4} \mathrm{C}$ slabs and over cylindrical $\mathrm{Al}$ insert

f. bare, at 30 and $150 \mathrm{~cm}, \mathrm{Cd}$ over Li-Par face above both front and side $\mathrm{B}_{4} \mathrm{C}$ slabs, also over cylindrical $\mathrm{Al}$ insert + $\mathrm{Cd}$ directly beneath concrete slabs overhead

g. bare and Cd-covered, at 30 and $150 \mathrm{~cm}, \mathrm{Cd}$ over Li-Par face above both front and side $\mathrm{B}_{4} \mathrm{C}$ slabs, also over cylindrical $\mathrm{Al}$ insert $+\mathrm{Cd}$ directly beneath concrete slabs overhead + $10.16 \mathrm{~cm} \mathrm{Li}$-Par covering front $\mathrm{B}_{4} \mathrm{C}$ face

B. $\quad \mathrm{SM}-3+13.05 \mathrm{~cm} \mathrm{~B}_{4} \mathrm{C}$ (with $\mathrm{Al}$ window) $+30.48 \mathrm{~cm} \mathrm{Na}$

1. Bare, Cd-covered, 3-, 5-, 8-, and 10-in Bonner ball measurements on centerline:

a. at $30 \mathrm{~cm}$ behind shield mockup

b. at $150 \mathrm{~cm}$ behind shield mockup (foreground only)

2. Bare Bonner ball measurements on centerline:

a. at 30 and $150 \mathrm{~cm}, \mathrm{Cd}$ sheet beneath concrete roof above detectors

b. $\quad$ at 30 and $150 \mathrm{~cm}, \mathrm{Cd}$ piece behind detectors

C. $\quad \mathrm{SM}-3+13.05 \mathrm{~cm} \mathrm{~B}_{4} \mathrm{C}$ (with $\mathrm{Al}$ window) $+61 \mathrm{~cm} \mathrm{Na}$

1. Bare, Cd-covered, 3-, 5-, 8-, and 10-in Bonner ball measurements on centerline:

a. at $30 \mathrm{~cm}$ behind shield mockup

b. at $150 \mathrm{~cm}$ behind shield mockup (foreground and background)

2. Bare Bonner ball measurements on centerline:

a. at 30 and $150 \mathrm{~cm}, \mathrm{Cd}$ sheet beneath concrete roof above detectors

b. at 30 and $150 \mathrm{~cm}, \mathrm{Cd}$ piece behind detectors

c. at $150 \mathrm{~cm}$ (background), Cd over face of shadow shield 
D. $\quad \mathrm{SM}-3+13.05 \mathrm{~cm} \mathrm{~B} \mathrm{C}_{4}$ (with $\mathrm{Al}$ window) $+91 \mathrm{~cm} \mathrm{Na}$

1. Bare, Cd-covered, 3-, 5-, 8-, and 10-in Bonner ball measurements on centerline:
a. at $30 \mathrm{~cm}$ behind shield mockup
b. at $150 \mathrm{~cm}$ behind shield mockup (foreground and background)

2. Bare Bonner ball measurements on centerline:
a. at 30 and $150 \mathrm{~cm}, \mathrm{Cd}$ piece behind detectors
b. at $150 \mathrm{~cm}$ (background), Cd over the face of the shadow shield

E. $\quad \mathrm{SM}-3+13.05 \mathrm{~cm} \mathrm{~B}{ }_{4} \mathrm{C}$ (with $\mathrm{Al}$ window) $+122 \mathrm{~cm} \mathrm{Na}$

1. Bare, Cd-covered, 3-, 5-, 8-, and 10-in Bonner ball measurements on centerline:
a. at $30 \mathrm{~cm}$ behind shield mockup
b. at $150 \mathrm{~cm}$ behind shield mockup (foreground and background)

2. Bare Bonner ball measurements on centerline:

a. at 30 and $150 \mathrm{~cm}, \mathrm{Cd}$ piece behind detectors

b. at $150 \mathrm{~cm}$ (background), Cd over face of shadow shield

3. Expose $\mathrm{Na}_{2} \mathrm{CO}_{3}$ capsules between mockup slabs on the horizontal centerline and on a parallel line $45.7 \mathrm{~cm}$ above the horizontal centerline

X. IHX Mockup (partial front shield - full side shields)

A. $\quad \mathrm{SM}-3+13.5 \mathrm{~cm} \mathrm{~B}$ C/Al

1. Bare, Cd-covered, 3-, 5-, 8-, and 10-in Bonner ball measurements on centerline:
a. at $30 \mathrm{~cm}$ behind shield mockup
b. at $150 \mathrm{~cm}$ behind shield mockup (foreground only)

2. Bare Bonner ball measurements on centerline:
a. at $150 \mathrm{~cm}, \mathrm{Cd}$ piece behind detector
b. at 30 and $150 \mathrm{~cm}, \mathrm{Cd}$ sheet beneath concrete roof above detector

B. $\quad \mathrm{SM}-3+13.5 \mathrm{~cm} \mathrm{~B} 4 \mathrm{C} / \mathrm{Al}+30.48 \mathrm{~cm} \mathrm{Na}$

1. Bare, Cd-covered, 3-, 5-, 8-, and 10-in Bonner ball measurements on centerline:
a. at $30 \mathrm{~cm}$ behind shield mockup
b. at $150 \mathrm{~cm}$ behind shield mockup (foreground only)

2. Bare Bonner ball measurements on centerline:
a. at $150 \mathrm{~cm}, \mathrm{Cd}$ piece behind detector
b. at 30 and $150 \mathrm{~cm}, \mathrm{Cd}$ sheet beneath concrete roof above detector
c. at 30 and $150 \mathrm{~cm}, \mathrm{Cd}$ sheet beneath concrete roof above detector and on the floor beneath detector


C. $\quad \mathrm{SM}-3+13.5 \mathrm{~cm} \mathrm{~B}{ }_{4} \mathrm{C} / \mathrm{Al}+61 \mathrm{~cm} \mathrm{Na}$

1. Bare, Cd-covered, 3-, 5-, 8-, and 10-in Bonner ball measurements on centerline:

a. at $30 \mathrm{~cm}$ behind shield mockup

b. at $150 \mathrm{~cm}$ behind shield mockup (foreground and background)

2. Bare Bonner ball measurements on centerline:

a. at $150 \mathrm{~cm}, \mathrm{Cd}$ piece behind detector

b. at $150 \mathrm{~cm}$ (background), Cd over the face of the shadow shield

c. at 30 and $150 \mathrm{~cm}, \mathrm{Cd}$ sheet beneath concrete roof above detector

D. $\quad \mathrm{SM}-3+13.5 \mathrm{~cm} \mathrm{~B} 4 \mathrm{C} / \mathrm{Al}+91 \mathrm{~cm} \mathrm{Na}$

1. Bare, Cd-covered, 3-, 5-, 8-, and 10-in Bonner ball measurements on centerline:

a. at $30 \mathrm{~cm}$ behind shield mockup

b. at $150 \mathrm{~cm}$ behind shield mockup (foreground and background)

2. Bare Bonner ball measurements on centerline:

a. at $30 \mathrm{~cm}, \mathrm{Cd}$ piece behind detector

b. at $150 \mathrm{~cm}$ (background), Cd over the face of the shadow shield

E. $\quad \mathrm{SM}-3+13.5 \mathrm{~cm} \mathrm{~B} \mathrm{C}_{4} \mathrm{C} / \mathrm{Al}+122 \mathrm{~cm} \mathrm{Na}$

1. Bare, Cd-covered, 3-, 5-, 8-, and 10-in Bonner ball measurements on centerline:

a. at $30 \mathrm{~cm}$ behind shield mockup

b. at $150 \mathrm{~cm}$ behind shield mockup (foreground and background)

2. Bare Bonner ball measurements on centerline:

a. at $30 \mathrm{~cm}, \mathrm{Cd}$ piece behind detector

b. at $150 \mathrm{~cm}$ (background), $\mathrm{Cd}$ over the face of the shadow shield

3. Horizontal traverses with the bare, Cd-covered, 3-, 5-, and 10-in Bonner balls at $30 \mathrm{~cm}$ behind shield mockup

4. Expose $\mathrm{Na}_{2} \mathrm{CO}_{3}$ capsules between mockup slabs on the horizontal centerline and on a parallel line $45.7 \mathrm{~cm}$ above the horizontal centerline 
APPENDIX B

TABLES OF DATA 

Table 1. Analysis of iron slabs ( $\rho=7.86 \mathrm{~g} / \mathrm{cc}$ ) used in spectrum modifier

\begin{tabular}{lc}
\hline Element & wt \% \\
\hline $\mathrm{Fe}$ & 98.4 \\
$\mathrm{C}$ & .25 \\
$\mathrm{Cr}$ & .15 \\
$\mathrm{Cu}$ & .03 \\
$\mathrm{Mn}$ & 1.0 \\
$\mathrm{Mo}$ & .02 \\
$\mathrm{Ni}$ & .05 \\
$\mathrm{Si}$ & .25 \\
\hline
\end{tabular}

Table 2. Analysis of 6061 aluminum $(\rho=2.70 \mathrm{~g} / \mathrm{cc}$ )

\begin{tabular}{ccr} 
Element & wt \% & ppm \\
& & \\
\hline $\mathrm{Al}$ & 97.5 & \\
$\mathrm{Cr}$ & .22 & \\
$\mathrm{Cu}$ & .23 & \\
$\mathrm{Fe}$ & .47 & \\
$\mathrm{Mg}$ & .86 & \\
$\mathrm{Mn}$ & .01 & \\
$\mathrm{Si}$ & .63 & \\
$\mathrm{Ti}$ & .042 & \\
$\mathrm{Zn}$ & .07 & \\
$\mathrm{Li}$ & & 3 \\
$\mathrm{Ni}$ & & 50 \\
$\mathrm{Sn}$ & & $<10$ \\
$\mathrm{~V}$ & & 150 \\
& & \\
\hline
\end{tabular}


Table 3. Composition of boral slabs used in spectrum modifier

\begin{tabular}{clcc}
\hline & \multicolumn{2}{c}{$\left(\mathrm{B}_{4} \mathrm{C}-40-43\right.$ vol \% in $\mathrm{B}_{4} \mathrm{C}-\mathrm{Al}$ mixture $)$} \\
\cline { 2 - 4 } Component & $\begin{array}{l}\text { Density } \\
(\mathrm{g} / \mathrm{cc})\end{array}$ & $\begin{array}{c}\text { Elemental } \\
\text { Composition } \\
(\text { wt \%) }\end{array}$ & $\begin{array}{c}\text { With } \\
\text { Al Cladding } \\
(\text { wt \%) }\end{array}$ \\
\hline & & & \\
$\mathrm{B}_{4} \mathrm{C}$ & 2.3 & 65 & $\sim 75$ \\
$\mathrm{Al}$ & 2.70 & 65 & $\sim 19.6$ \\
$\mathrm{~B}$ & & 27.5 & $\sim 5.4$ \\
$\mathrm{C}$ & & 7.5 & \\
\hline
\end{tabular}

Table 4. Composition of rectangular sodium slabs $(\rho=0.945 \mathrm{~g} / \mathrm{cc})$

\begin{tabular}{cc}
\hline Element & wt \% \\
\hline $\mathrm{Na}$ & 99.7 \\
$\mathrm{Ca}, \mathrm{Zn}$ & 0.3 \\
\hline
\end{tabular}


Table 5. Composition of the small concrete blocks on each side of the spectrum modifier $(\rho=2.39 \mathrm{~g} / \mathrm{cc})$

\begin{tabular}{cc}
\hline Element & wt \% \\
\hline $\mathrm{C}$ & 10.36 \\
$\mathrm{O}$ & 49.03 \\
$\mathrm{Ca}$ & 38.05 \\
$\mathrm{Fe}$ & 0.37 \\
$\mathrm{Si}$ & 0.78 \\
$\mathrm{Mg}$ & 0.23 \\
$\mathrm{~S}$ & 0.17 \\
$\mathrm{P}$ & 0.04 \\
$\mathrm{Na}$ & 0.03 \\
$\mathrm{~K}$ & 0.04 \\
$\mathrm{H}$ & 0.42 \\
$\mathrm{R}^{*}$ & 0.47 \\
& 99.99
\end{tabular}

${ }^{*} \mathrm{R}$ is an unspecified mix of $\mathrm{Al}, \mathrm{Ti}, \mathrm{Cr}$, and possibly other trace metals. 
Table 6. Analysis of $61-\mathrm{cm} \times 61-\mathrm{cm} \times 30.5-\mathrm{cm}(\rho=2.40 \mathrm{~g} / \mathrm{cc})$ concrete blocks used to surround configuration

\begin{tabular}{cccc}
\hline Component & wt\% & Component & wt $\%$ \\
\hline $\mathrm{CO}_{3}$ & 41.9 & $\mathrm{Al}_{2} \mathrm{O}_{3}$ & 2.2 \\
$\mathrm{Ca}$ & 27.4 & $\mathrm{Fe}_{2} \mathrm{O}_{3}$ & .60 \\
$\mathrm{SiO}_{2}$ & 18.1 & $\mathrm{SO}_{3}$ & .32 \\
$\mathrm{H}_{2} \mathrm{O}$ & 4.0 & $\mathrm{P}_{2} \mathrm{O}_{5}$ & .035 \\
$\mathrm{Mg}$ & 3.66 & $\mathrm{~K}$ & .30 \\
$\mathrm{O}_{2}$ & 1.4 & & \\
\hline
\end{tabular}


Table 7. Analysis of concrete slabs on top of the mockup $(p=2.68 \mathrm{~g} / \mathrm{cc})$

\begin{tabular}{cc}
\hline Element & Wt\% \\
$\mathrm{MgO}$ & 14.11 \\
$\mathrm{SiO}_{2}$ & 9.17 \\
$\mathrm{CaO}$ & 34.18 \\
$\mathrm{Al}_{2} \mathrm{O}_{3}$ & 2.02 \\
$\mathrm{Fe}_{2} \mathrm{O}_{3}$ & 1.0 \\
$\mathrm{SO}_{3}$ & .52 \\
$\mathrm{Na}_{2} \mathrm{O}$ & .24 \\
$\mathrm{~K}_{2} \mathrm{O}$ & .58 \\
$\mathrm{P}_{2} \mathrm{O}_{5}$ & .06 \\
$\mathrm{LOI}^{*}$ & 38.54 \\
\hline
\end{tabular}

* LOI (Lost on ignition) includes the free and bound $\mathrm{H}_{2} \mathrm{O}, \mathrm{SO}_{3}$, and $\mathrm{CO}_{2}$. 
Table 8. Composition of lithiated paraffin bricks ( $\rho=1.15 \mathrm{~g} / \mathrm{cc}$ )

\begin{tabular}{ll}
\hline Component & wt \% \\
\hline $\mathrm{C}_{\mathrm{n}} \mathrm{H}_{2 \mathrm{n}+2}$ & 60 \\
$\mathrm{Li}_{2} \mathrm{CO}_{3}$ & 40 \\
\hline
\end{tabular}

Table 9. Maximum impurities in the cylindrical sodium slab $(p=0.945 \mathrm{~g} / \mathrm{cc})$

\begin{tabular}{cc}
\hline Element & ppm \\
\hline Hydrogen & 60 \\
Oxygen & 200 \\
Potassium & 150 \\
Calcium & 400 \\
\hline
\end{tabular}


Table 10. Analysis of concrete around the cylindrical sodium tanks

\begin{tabular}{cc}
\hline Element & $\underline{\mathrm{Wt} \%}$ \\
$\mathrm{LOI}^{*}$ & 33.2 \\
$\mathrm{CaO}$ & 39.9 \\
$\mathrm{MgO}$ & 4.1 \\
$\mathrm{SO}_{3}$ & .48 \\
$\mathrm{SiO}_{2}$ & 16.4 \\
$\mathrm{P}_{2} \mathrm{O}_{5}$ & .09 \\
$\mathrm{~K}_{2} \mathrm{O}$ & 7.84 \\
$\mathrm{Na}_{2} \mathrm{O}$ & .06 \\
\hline
\end{tabular}

"LOI (Lost on ignition) includes the free and bound $\mathrm{H}_{2} \mathrm{O}, \mathrm{SO}_{3}$, and $\mathrm{CO}_{2}$. 
Table 11. Analysis of boron carbide used in shield mockups

\begin{tabular}{|c|c|c|}
\hline Element & wt\% & ppm \\
\hline $\mathrm{B}$ & 76.7 & \\
\hline $\mathrm{C}$ & 19.52 & \\
\hline $\mathrm{Al}$ & & 50 \\
\hline $\mathrm{Ca}$ & & 800 \\
\hline $\mathrm{Cl}$ & & 10 \\
\hline Co & & $<1$ \\
\hline $\mathrm{Cr}$ & & 2 \\
\hline $\mathrm{Cu}$ & & $<1$ \\
\hline $\mathrm{Fe}$ & & 600 \\
\hline $\mathrm{Mg}$ & & 25 \\
\hline $\mathrm{Mn}$ & & 10 \\
\hline $\mathrm{Na}$ & & 1 \\
\hline$P$ & & 2 \\
\hline $\mathbf{S}$ & & 5 \\
\hline $\mathrm{Si}$ & & 50 \\
\hline $\mathrm{Ti}$ & & 225 \\
\hline
\end{tabular}


Table 12. Analysis of type 304 stainless steel in boron carbide containers $(6 \mathrm{~W}, 7 \mathrm{~W}, 8 \mathrm{~W})$ $(\rho=7.92 \mathrm{~g} / \mathrm{cc})$

\begin{tabular}{cc}
\hline Element & Wt\% \\
\hline As & .008 \\
$\mathrm{Co}$ & .20 \\
$\mathrm{Cr}$ & 18.3 \\
$\mathrm{Cu}$ & .40 \\
$\mathrm{Fe}$ & 70.0 \\
$\mathrm{Ga}$ & .01 \\
$\mathrm{Mn}$ & 1.40 \\
$\mathrm{Mo}$ & .20 \\
$\mathrm{Nb}$ & .03 \\
$\mathrm{Ni}$ & 8.7 \\
$\mathrm{Si}$ & .35 \\
$\mathrm{Ti}$ & .033 \\
$\mathrm{~V}$ & .23 \\
\hline
\end{tabular}


Table 13. Analysis of lead slabs $(\rho=11.35 \mathrm{~g} / \mathrm{cc})$

\begin{tabular}{ccc}
\hline Element & wt\% & PPM \\
\hline $\mathrm{Pb}$ & 99.9 & \\
$\mathrm{Al}$ & & $<3$ \\
$\mathrm{Ag}$ & & 30 \\
$\mathrm{~B}$ & & $<1$ \\
$\mathrm{Ca}$ & 1 \\
$\mathrm{Cr}$ & 10 \\
$\mathrm{Cu}$ & & 800 \\
$\mathrm{Fe}$ & 1 \\
$\mathrm{Li}$ & & 20 \\
$\mathrm{Mg}$ & & $<3$ \\
$\mathrm{Mn}$ & & 5 \\
$\mathrm{Na}$ & & 1 \\
$\mathrm{Ni}$ & 30 \\
$\mathrm{P}$ & & 5 \\
$\mathrm{Si}$ & $<3$ \\
$\mathrm{Sn}$ & & 30 \\
\hline
\end{tabular}




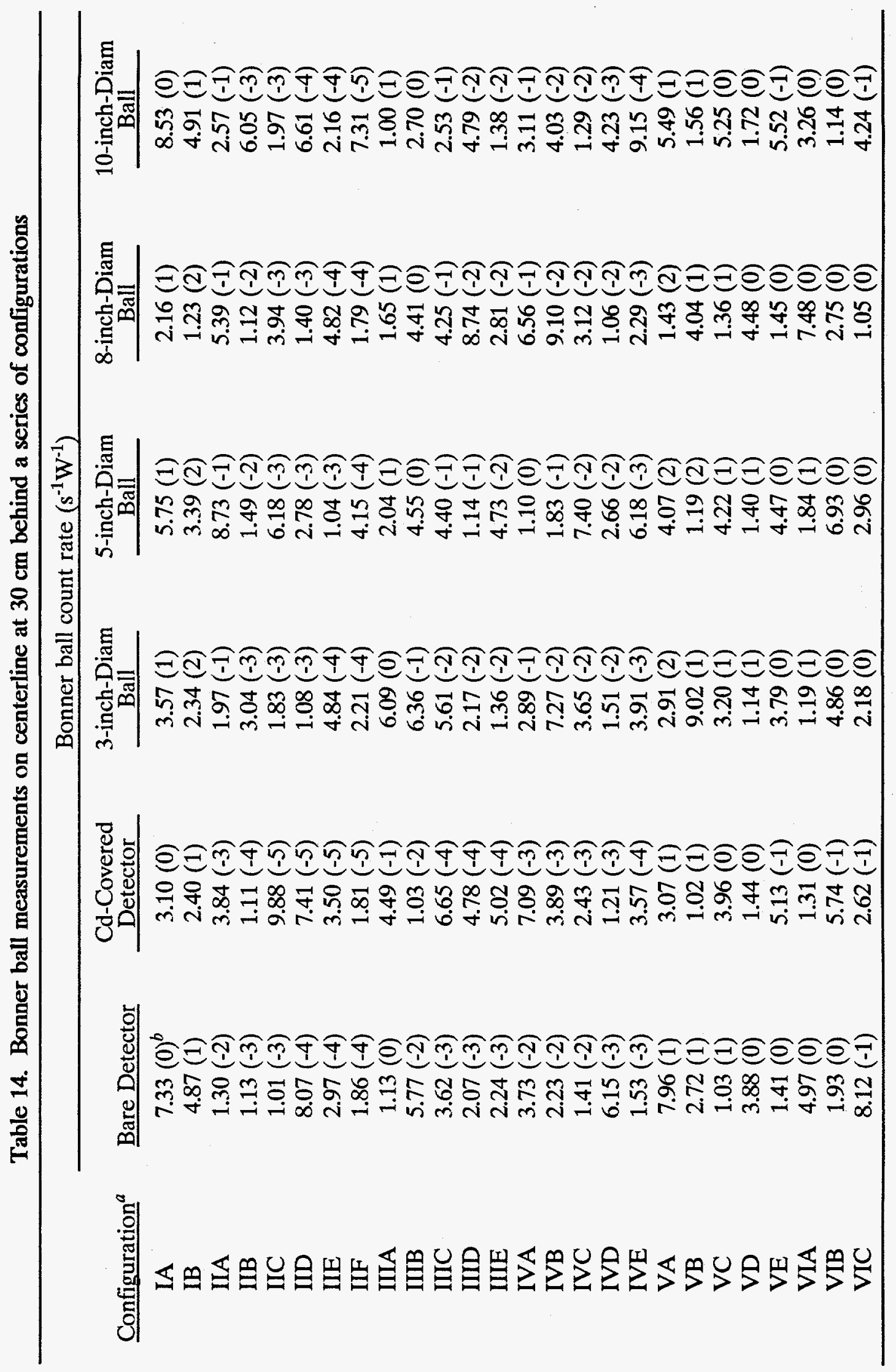


Table 14. (continued)

\begin{tabular}{|c|c|c|c|c|c|c|}
\hline \multirow[b]{2}{*}{ Configuration } & \multicolumn{6}{|c|}{ Bonner ball count rate $\left(\mathrm{s}^{-1} \mathrm{~W}^{-1}\right)$} \\
\hline & Bare Detector & $\begin{array}{c}\text { Cd-Covered } \\
\text { Detector } \\
\end{array}$ & $\begin{array}{c}\text { 3-inch-Diam } \\
\text { Ball } \\
\end{array}$ & $\begin{array}{c}\text { 5-inch-Diam } \\
\text { Ball } \\
\end{array}$ & $\begin{array}{c}\text { 8-inch-Diam } \\
\text { Ball }\end{array}$ & $\begin{array}{c}\text { 10-inch-Diam } \\
\text { Ball }\end{array}$ \\
\hline VID & $3.04(-1)$ & $9.85(-2)$ & $7.99(-1)$ & $1.04(0)$ & $3.61(-1)$ & $1.41(-1)$ \\
\hline VIE & $1.29(-1)$ & $3.71(-2)$ & $2.89(-1)$ & $3.54(-1)$ & $1.18(-1)$ & $4.71(-2)$ \\
\hline VIIA & $6.42(1)$ & $2.62(1)$ & $2.50(2)$ & $3.60(2)$ & $1.28(2)$ & $5.16(1)$ \\
\hline VIIB & $9.20(-1)$ & $8.87(-2)$ & $1.33(0)$ & $4.38(0)$ & $2.89(0)$ & $1.51(0)$ \\
\hline VIIC & $2.19(-1)$ & $5.64(-2)$ & $7.18(-1)$ & $1.81(0)$ & $9.70(-1)$ & $4.66(-1)$ \\
\hline VIID & $1.56(-1)$ & $4.30(-2)$ & $4.61(-1)$ & $8.79(-1)$ & $3.96(-1)$ & $1.74(-1)$ \\
\hline VIIE & $7.19(-2)$ & $1.88(-2)$ & $1.97(-1)$ & $3.50(-1)$ & $1.43(-1)$ & $5.96(-2)$ \\
\hline VIIF & $4.04(-2)$ & $8.17(-3)$ & $8.30(-2)$ & $1.35(-1)$ & $5.20(-2)$ & $2.13(-2)$ \\
\hline VIIIA & $6.31(1)$ & $2.60(1)$ & $2.49(2)$ & $3.66(2)$ & $1.28(2)$ & $5.17(1)$ \\
\hline VIIIB & $5.76(-1)$ & $5.42(-2)$ & $1.07(0)$ & $4.02(0)$ & $2.75(0)$ & $1.47(0)$ \\
\hline VIIIC & $9.89(-2)$ & $2.50(-2)$ & $4.60(-1)$ & $1.37(0)$ & $8.61(-1)$ & $4.27(-1)$ \\
\hline VIIID & $5.10(-2)$ & $1.33(-2)$ & $2.25(-1)$ & $5.65(-1)$ & $2.92(-1)$ & $1.33(-1)$ \\
\hline VIIIE & $3.70(-2)$ & $7.33(-3)$ & $1.06(-1)$ & $2.25(-1)$ & $1.03(-1)$ & $4.46(-2)$ \\
\hline VIIIF & $3.14(-2)$ & $4.39(-3)$ & $5.33(-2)$ & $9.72(-2)$ & $4.00(-2)$ & $1.68(-2)$ \\
\hline IXA & $1.63(0)$ & $5.69(-1)$ & $6.00(0)$ & $1.11(1)$ & $5.18(0)$ & $2.41(0)$ \\
\hline IXB & $1.97(-1)$ & $8.00(2)$ & $1.02(0)$ & $2.23(0)$ & $1.10(0)$ & $5.24(-1)$ \\
\hline IXC & $7.92(-2)$ & $2.91(-2)$ & $3.62(-1)$ & $7.44(-1)$ & $3.46(-1)$ & $1.56(-1)$ \\
\hline IXD & $4.29(-2)$ & $1.30(-2)$ & $1.53(-1)$ & $2.83(-1)$ & $1.20(-1)$ & $5.20(-2)$ \\
\hline IXE & $3.17(-2)$ & $6.05(-3)$ & $6.57(-2)$ & $1.12(-1)$ & $4.44(-2)$ & $1.87(-2)$ \\
\hline $\mathrm{XA}$ & $1.77(1)$ & $7.55(0)$ & $7.06(1)$ & $1.08(2)$ & $3.74(1)$ & $1.49(1)$ \\
\hline XB & $6.18(0)$ & $2.68(0)$ & $2.40(1)$ & $3.26(1)$ & $1.13(1)$ & $4.41(0)$ \\
\hline $\mathrm{XC}$ & $2.40(0)$ & $1.01(0)$ & $8.44(0)$ & $1.08(1)$ & $3.69(0)$ & $1.43(0)$ \\
\hline $\mathrm{XD}$ & $8.70(-1)$ & $3.55(-1)$ & $2.84(0)$ & $3.53(0)$ & $1.16(0)$ & $4.39(-1)$ \\
\hline $\mathrm{XE}$ & $3.28(-1)$ & $1.25(-1)$ & $9.48(-1)$ & $1.16(0)$ & $3.67(-1)$ & $1.40(-1)$ \\
\hline
\end{tabular}

${ }^{a}$ See experimental program plan in Appendix A for description of configurations.

${ }^{b}$ Read: $7.33 \times 10^{0}$. 
Table 15. Bonner ball measurements on centerline at $150 \mathrm{~cm}$ behind a series of configurations

\begin{tabular}{|c|c|c|c|c|c|c|}
\hline \multirow[b]{3}{*}{$\underline{\text { Configuration }}^{a}$} & \multicolumn{6}{|c|}{ Bonner ball count rate $\left(\mathrm{s}^{-1} \mathrm{~W}^{-1}\right)$} \\
\hline & \multicolumn{2}{|c|}{ Bare Detector } & \multicolumn{2}{|c|}{ Cd-Covered Detector } & \multicolumn{2}{|c|}{ 3-inch-Diam Ball } \\
\hline & $\underline{\text { Foreground }}^{b}$ & $\underline{\text { Background }}^{c}$ & Foreground & Background & Foreground & Background \\
\hline IA & $2.18(0)^{d}$ & $5.44(-1)$ & $7.15(-1)$ & $7.43(-2)$ & $7.76(0)$ & $5.98(-1)$ \\
\hline IB & $1.93(1)$ & $3.63(0)$ & $8.21(0)$ & $7.34(-1)$ & $7.91(1)$ & $6.26(0)$ \\
\hline IIA & $8.59(-3)$ & $4.34(-3)$ & $1.79(-3)$ & $4.30(-4)$ & $5.25(-2)$ & $6.10(-3)$ \\
\hline IIB & $1.35(-3)$ & $1.10(-3)$ & $9.99(-5)$ & $5.84(-5)$ & $1.45(-3)$ & $6.07(-4)$ \\
\hline IIC & $1.16(-3)$ & $1.07(-3)$ & $7.53(-5)$ & $5.30(-5)$ & $9.03(-4)$ & $5.51(-4)$ \\
\hline IID & $1.14(-3)$ & $1.05(-3)$ & $6.38(-5)$ & $5.08(-5)$ & $6.81(-4)$ & $4.92(-4)$ \\
\hline IIE & $2.74(-4)$ & $2.03(-4)$ & $1.80(-5)$ & $8.59(-6)$ & $1.89(-4)$ & $7.73(-5)$ \\
\hline IIF & $1.82(-4)$ & $1.67(-4)$ & $9.52(-6)$ & $5.18(-6)$ & $9.34(-5)$ & $4.86(-5)$ \\
\hline IIIA & $3.55(-1)$ & $1.86(-1)$ & $9.31(-2)$ & $1.93(-2)$ & $1.14(0)$ & $2.09(-1)$ \\
\hline IIIB & $2.52(-2)$ & $2.21(-2)$ & $3.14(-3)$ & $2.01(-3)$ & $1.09(-1)$ & $2.91(-2)$ \\
\hline IIIC & $2.54(-3)$ & $2.38(-3)$ & $2.47(-4)$ & $1.70(-4)$ & $1.04(-2)$ & $2.26(-3)$ \\
\hline IIID & $1.62(-3)$ & $1.48(-3)$ & $1.73(-4)$ & $9.51(-5)$ & $4.54(-3)$ & $1.06(-3)$ \\
\hline IIIE & $1.73(-3)$ & $1.31(-3)$ & $1.83(-4)$ & $7.19(-5)$ & $3.49(-3)$ & $7.64(-4)$ \\
\hline IVA & $3.40(-2)$ & $2.33(-2)$ & $4.83(-3)$ & $2.03(-3)$ & $9.89(-2)$ & $2.53(-2)$ \\
\hline IVB & $1.85(-2)$ & $1.14(-2)$ & $1.83(-3)$ & $8.22(-4)$ & $2.46(-2)$ & $8.45(-3)$ \\
\hline IVC & $1.04(-2)$ & $5.88(-3)$ & $1.02(-3)$ & $4.04(-4)$ & $1.19(-2)$ & $3.80(-3)$ \\
\hline IVD & $4.34(-3)$ & $2.45(-3)$ & $4.57(-4)$ & $1.53(-4)$ & $4.71(-3)$ & $1.35(-3)$ \\
\hline IVE & $1.10(-3)$ & $6.53(-4)$ & $1.21(-4)$ & $4.08(-5)$ & $1.19(-3)$ & $3.31(-4)$ \\
\hline VA & $3.51(1)$ & & $1.06(1)$ & & $9.60(1)$ & \\
\hline VB & 9.70 (0) & & $2.98(0)$ & & $2.58(1)$ & \\
\hline VC & $3.40(0)$ & $5.83(-1)$ & $1.05(0)$ & $6.66(-2)$ & $8.27(0)$ & $5.18(-1)$ \\
\hline VD & $1.20(0)$ & $2.51(-1)$ & $3.61(-1)$ & $2.62(-2)$ & $2.81(0)$ & $1.90(-1)$ \\
\hline VE & $4.77(-1)$ & $1.20(-1)$ & $1.35(-1)$ & $9.83(-3)$ & $9.73(-1)$ & $6.81(-2)$ \\
\hline VIA & $2.56(0)$ & & $6.22(-1)$ & & $5.50(0)$ & \\
\hline VIB & $8.68(-1)$ & & $2.32(-1)$ & & $1.91(0)$ & \\
\hline
\end{tabular}


Table 15. (continued)

\begin{tabular}{|c|c|c|c|c|c|c|}
\hline \multirow[b]{3}{*}{ Configuration } & \multicolumn{6}{|c|}{ Bonner ball count rate $\left(\mathrm{s}^{-1} \mathrm{~W}^{-1}\right)$} \\
\hline & \multicolumn{2}{|c|}{$\underline{\text { Bare Detector }}$} & \multicolumn{2}{|c|}{ Cd-Covered Detector } & \multicolumn{2}{|c|}{ 3-inch-Diam Ball } \\
\hline & Foreground & Background & Foreground & Background & Foreground & Background \\
\hline VIC & $3.30(-1)$ & $7.48(-2)$ & $8.42(-2)$ & $5.82(-3)$ & $7.03(-1)$ & $4.55(-2)$ \\
\hline VID & $1.31(-1)$ & $5.33(-2)$ & $3.00(-2)$ & $3.31(-3)$ & $2.32(-1)$ & $2.66(-2)$ \\
\hline VIE & $6.91(-2)$ & $1.79(-3)$ & $1.17(-2)$ & $4.15(-2)$ & $8.88(-2)$ & $1.46(-2)$ \\
\hline VIIA & $2.78(1)$ & & $8.72(0)$ & & $8.07(1)$ & \\
\hline VIIB & $6.49(-1)$ & & $7.85(-2)$ & & $8.25(-1)$ & \\
\hline VIIC & $1.42(-1)$ & & $2.91(-2)$ & & $3.05(-1)$ & \\
\hline VIID & $7.96(-2)$ & $3.49(-2)$ & $1.47(-2)$ & $2.11(-3)$ & $1.48(-1)$ & $1.88(-2)$ \\
\hline VIIE & $5.01(-2)$ & $3.32(-2)$ & $7.23(-3)$ & $1.60(-3)$ & $6.98(-2)$ & $1.32(-2)$ \\
\hline VIIF & $3.80(-2)$ & $3.09(-2)$ & $3.70(-3)$ & $1.31(-3)$ & $3.42(-2)$ & $1.11(-2)$ \\
\hline VIIIA & $2.52(1)$ & & $7.94(0)$ & & $7.42(1)$ & \\
\hline VIIIB & $3.72(-1)$ & & $3.94(-2)$ & & $5.09(-1)$ & \\
\hline VIIIC & $8.02(-2)$ & & $1.36(-2)$ & & $1.77(-1)$ & \\
\hline VIIID & $4.39(-2)$ & $3.28(-2)$ & $5.42(-3)$ & $1.43(-3)$ & $6.96(-2)$ & $1.34(-2)$ \\
\hline VIIIE & $3.99(-2)$ & $3.39(-2)$ & $3.06(-3)$ & $1.30(-3)$ & $3.52(-2)$ & $1.12(-2)$ \\
\hline VIIIF & $3.65(-2)$ & $3.02(-2)$ & $2.23(-3)$ & $1.16(-3)$ & $2.25(-2)$ & $1.05(-2)$ \\
\hline IXA & $5.47(-1)$ & & $8.48(-2)$ & & $9.16(-1)$ & \\
\hline IXB & $8.57(-2)$ & & $2.01(-2)$ & & $2.52(-1)$ & \\
\hline IXC & $4.60(-2)$ & $2.77(-2)$ & $8.39(-3)$ & $1.54(-3)$ & $9.50(-2)$ & $1.43(-2)$ \\
\hline IXD & $3.48(-2)$ & $2.70(-2)$ & $4.12(-3)$ & $1.24(-3)$ & $4.37(-2)$ & $1.15(-2)$ \\
\hline IXE & $3.35(-2)$ & $2.93(-2)$ & $2.57(-3)$ & $1.20(-3)$ & $2.46(-2)$ & $1.08(-2)$ \\
\hline $\mathrm{XA}$ & $6.88(0)$ & & $2.21(0)$ & & $2.00(1)$ & \\
\hline XB & $2.10(0)$ & & $7.10(-1)$ & & $6.11(0)$ & \\
\hline $\mathrm{XC}$ & $7.33(-1)$ & $1.19(-1)$ & $2.44(-1)$ & $1.26(-2)$ & $1.95(0)$ & $1.01(-1)$ \\
\hline$X D$ & $2.60(-1)$ & $6.93(-2)$ & $8.11(-2)$ & $5.49(-3)$ & $6.52(-1)$ & $4.08(-2)$ \\
\hline $\mathrm{XE}$ & $1.05(-1)$ & $4.31(-2)$ & $2.86(-2)$ & $2.81(-3)$ & $2.21(-1)$ & $2.21(-2)$ \\
\hline
\end{tabular}


Table 15. (continued)

\begin{tabular}{|c|c|c|c|c|c|c|}
\hline \multirow[b]{3}{*}{$\underline{\text { Configuration }}$} & \multicolumn{6}{|c|}{ Bonner ball count rate $\left(\mathrm{s}^{-1} \mathrm{~W}^{-1}\right)$} \\
\hline & \multicolumn{2}{|c|}{ 5-inch-Diam Ball } & \multicolumn{2}{|c|}{ 8-inch-Diam Ball } & \multicolumn{2}{|c|}{ 10-inch-Diam Ball } \\
\hline & Foreground & Background & Foreground & Background & Foreground & Background \\
\hline IA & $1.20(1)$ & $9.49(-1)$ & $4.59(0)$ & $3.34(-1)$ & $1.81(0)$ & $1.38(-1)$ \\
\hline IB & $1.10(2)$ & $8.37(0)$ & $3.82(1)$ & $2.56(0)$ & $1.55(1)$ & $1.09(0)$ \\
\hline IIA & $2.04(-1)$ & $1.42(-2)$ & $1.23(-1)$ & $6.93(-3)$ & $5.90(-2)$ & $3.27(-3)$ \\
\hline IIB & $4.75(-3)$ & $1.36(-3)$ & $3.20(-3)$ & $6.47(-4)$ & $1.70(-3)$ & $3.06(-4)$ \\
\hline IIC & $2.22(-3)$ & $1.05(-3)$ & $1.27(-3)$ & $4.83(-4)$ & $6.16(-4)$ & $2.16(-4)$ \\
\hline IID & $1.46(-3)$ & $9.32(-4)$ & $6.75(-4)$ & $4.06(-4)$ & $3.11(-4)$ & $1.78(-4)$ \\
\hline IIE & $3.53(-4)$ & $1.30(-4)$ & $1.56(-4)$ & $5.20(-5)$ & $6.93(-5)$ & $2.22(-5)$ \\
\hline IIF & $1.61(-4)$ & $7.59(-5)$ & $6.63(-5)$ & $2.89(-5)$ & $2.72(-5)$ & $1.28(-5)$ \\
\hline IIIA & $3.27(0)$ & $4.94(-1)$ & $2.41(0)$ & $2.99(-1)$ & $1.43(0)$ & $1.54(-1)$ \\
\hline IIIB & $6.85(-1)$ & $8.83(-2)$ & $6.51(-1)$ & $5.72(-2)$ & $3.95(-1)$ & $2.94(-2)$ \\
\hline IIIC & $7.19(-2)$ & $6.74(-3)$ & $7.39(-2)$ & $4.15(-3)$ & $4.20(-2)$ & $2.17(-3)$ \\
\hline IIID & $2.08(-2)$ & $2.48(-3)$ & $1.58(-2)$ & $1.26(-3)$ & $8.71(-3)$ & $6.13(-4)$ \\
\hline IIIE & $1.05(-2)$ & $1.52(-3)$ & $6.07(-3)$ & $6.94(-4)$ & $2.94(-3)$ & $3.02(-4)$ \\
\hline IVA & $3.01(-1)$ & $5.26(-2)$ & $1.71(-1)$ & $2.33(-2)$ & $7.82(-2)$ & $1.02(-2)$ \\
\hline IVB & $5.34(-2)$ & $1.50(-2)$ & $2.53(-2)$ & $6.21(-3)$ & $1.10(-2)$ & $2.58(-3)$ \\
\hline IVC & $2.20(-2)$ & $5.98(-3)$ & $8.95(-3)$ & $2.24(-3)$ & $3.65(-3)$ & $9.02(-4)$ \\
\hline IVD & $7.66(-3)$ & $1.98(-3)$ & $3.00(-3)$ & $7.11(-4)$ & $1.20(-3)$ & $2.85(-4)$ \\
\hline IVE & $1.78(-3)$ & $4.63(-4)$ & $6.62(-4)$ & $1.66(-4)$ & $2.61(-4)$ & $6.53(-5)$ \\
\hline VA & $1.31(2)$ & & $4.62(1)$ & & $1.78(1)$ & \\
\hline VB & $3.33(1)$ & & $1.13(1)$ & & $4.37(0)$ & \\
\hline $\mathrm{VC}$ & $1.07(1)$ & $6.28(-1)$ & $3.47(0)$ & $1.46(-1)$ & $1.31(0)$ & $5.97(-2)$ \\
\hline VD & $3.44(0)$ & $2.22(-1)$ & $1.11(0)$ & $5.85(-2)$ & $4.19(-1)$ & $2.29(-2)$ \\
\hline VE & $1.14(0)$ & $8.23(-2)$ & $3.68(-1)$ & $2.59(-2)$ & $1.41(-1)$ & $1.03(-2)$ \\
\hline VIA & $8.01(0)$ & & $3.11(0)$ & & $1.32(0)$ & \\
\hline VIB & $2.64(0)$ & & $9.88(-1)$ & & $4.01(-1)$ & \\
\hline
\end{tabular}


Table 15. (continued)

\begin{tabular}{|c|c|c|c|c|c|c|}
\hline \multirow[b]{3}{*}{ Configuration } & \multicolumn{6}{|c|}{ Bonner ball count rate $\left(\mathrm{s}^{-1} \mathrm{~W}^{-1}\right)$} \\
\hline & \multicolumn{2}{|c|}{ 5-inch-Diam Ball } & \multicolumn{2}{|c|}{ 8-inch-Diam Ball } & \multicolumn{2}{|c|}{ 10-inch-Diam Ball } \\
\hline & Foreground & Background & Foreground & $\underline{\text { Background }}$ & Foreground & Background \\
\hline VIC & $9.34(-1)$ & $5.92(-2)$ & $3.20(-1)$ & $2.08(-2)$ & $1.31(-1)$ & $8.42(-3)$ \\
\hline VID & $3.00(-1)$ & $3.59(-2)$ & $1.05(-1)$ & $1.18(-2)$ & $4.08(-2)$ & $4.75(-3)$ \\
\hline VIE & $1.08(-1)$ & $2.08(-2)$ & $3.83(-2)$ & $7.76(-3)$ & $1.47(-2)$ & $3.20(-3)$ \\
\hline VIIA & $1.12(2)$ & & $4.01(1)$ & & $1.58(1)$ & \\
\hline VIIB & $1.82(0)$ & & $1.05(0)$ & & $5.18(-1)$ & \\
\hline VIIC & $6.24(-1)$ & & $3.10(-1)$ & & $1.46(-1)$ & \\
\hline VIID & $2.59(-1)$ & $2.96(-2)$ & $1.12(-1)$ & $9.92(-3)$ & $4.92(-2)$ & $4.19(-3)$ \\
\hline VIIE & $1.11(-1)$ & $2.19(-2)$ & $4.47(-2)$ & $7.21(-3)$ & $1.85(-2)$ & $2.92(-3)$ \\
\hline VIIF & $5.28(-2)$ & $1.78(-2)$ & $2.01(-2)$ & $7.17(-3)$ & $8.17(-3)$ & $2.97(-3)$ \\
\hline VIIIA & $1.05(2)$ & & $3.78(1)$ & & $1.49(1)$ & \\
\hline VIIIB & $1.43(0)$ & & $8.78(-1)$ & & $4.38(-1)$ & \\
\hline VIIIC & $4.51(-1)$ & & $2.51(-1)$ & & $1.21(-1)$ & \\
\hline VIIID & $1.57(-1)$ & $2.24(-2)$ & $7.81(-2)$ & $7.65(-3)$ & $3.59(-2)$ & $3.23(-3)$ \\
\hline VIIIE & $6.65(-2)$ & $1.84(-2)$ & $2.97(-2)$ & $6.53(-3)$ & $1.27(-2)$ & $2.70(-3)$ \\
\hline VIIIF & $3.76(-2)$ & $1.63(-2)$ & $1.53(-2)$ & $6.67(-3)$ & $6.36(-3)$ & $2.79(-3)$ \\
\hline IXA & $1.97(0)$ & & $1.06(0)$ & & $5.16(-1)$ & \\
\hline $\mathrm{IXB}$ & $5.43(-1)$ & & $2.82(-1)$ & & $1.35(-1)$ & \\
\hline IXC & $1.89(-1)$ & $2.39(-2)$ & $8.96(-2)$ & $8.15(-3)$ & $3.93(-2)$ & $3.48(-3)$ \\
\hline IXD & $7.76(-2)$ & $1.80(-2)$ & $3.26(-2)$ & $6.48(-3)$ & $1.38(-2)$ & $2.74(-3)$ \\
\hline IXE & $3.99(-2)$ & $1.71(-2)$ & $1.58(-2)$ & $6.69(-3)$ & $6.72(-3)$ & $2.81(-3)$ \\
\hline $\mathrm{XA}$ & $2.95(1)$ & & $1.06(1)$ & & $4.14(0)$ & \\
\hline $\mathrm{XB}$ & $8.30(0)$ & & $2.81(0)$ & & $1.11(0)$ & \\
\hline $\mathrm{XC}$ & $2.49(0)$ & $1.29(-1)$ & $8.66(-1)$ & $3.51(-2)$ & $3.27(-1)$ & $1.38(-2)$ \\
\hline $\mathrm{XD}$ & $8.03(-1)$ & $5.22(-2)$ & $2.64(-1)$ & $1.56(-2)$ & $9.90(-2)$ & $6.24(-3)$ \\
\hline $\mathrm{XE}$ & $2.72(-1)$ & $3.01(-2)$ & $8.78(-2)$ & $1.03(-2)$ & $3.31(-2)$ & $4.21(-3)$ \\
\hline
\end{tabular}

${ }^{a}$ See experimental program plan in Appendix A for description of experiment.

${ }^{b}$ Count rates without shadow shield between detector and configuration.

${ }^{c}$ Count rates with shadow shield between detector and configuration.

${ }^{d}$ Read: $2.18 \times 10^{0}$ 
Table 16. Sodium foil measurements in voids located in the spectrum modifiers

\begin{tabular}{|c|c|c|c|c|}
\hline \multicolumn{2}{|c|}{$\underline{\text { Foil Location }}^{a}$} & \multicolumn{3}{|c|}{$\mathrm{S}(\mathrm{nCi}) / \mathrm{kW} / \mathrm{g}(\mathrm{Na}) /$ minute of exposure } \\
\hline Void & $\underline{\text { Position }}$ & $\underline{\text { Item } \text { IA }^{c}}$ & $\underline{\text { Item IAA }}^{e}$ & $\underline{\text { Item IB }}$ \\
\hline $\mathrm{X}$ & $\begin{array}{l}1 \\
2 \\
3 \\
4 \\
5 \\
6 \\
7 \\
8 \\
9\end{array}$ & & $\begin{array}{l}5.44(-2) \\
6.18(-2) \\
5.58(-2) \\
5.83(-2) \\
5.99(-2) \\
5.94(-2) \\
5.65(-2) \\
5.48(-2)\end{array}$ & \\
\hline $\mathbf{Y}$ & $\begin{array}{l}1 \\
2 \\
3 \\
4 \\
5 \\
6 \\
7 \\
8 \\
9\end{array}$ & & $\begin{array}{l}1.52(-2) \\
1.84(-2) \\
1.44(-2) \\
1.73(-2) \\
1.89(-2) \\
1.65(-2) \\
1.55(-2) \\
1.72(-2) \\
1.54(-2)\end{array}$ & \\
\hline $\mathbf{Z}$ & $\begin{array}{l}1 \\
2 \\
3 \\
4 \\
5 \\
6 \\
7 \\
8 \\
9\end{array}$ & $\begin{array}{l}1.63(-3)^{d} \\
1.64(-3) \\
1.70(-3) \\
1.79(-3) \\
1.84(-3) \\
1.72(-3) \\
1.59(-3) \\
1.64(-3) \\
1.51(-3)\end{array}$ & & \\
\hline $\mathrm{XX}$ & $\begin{array}{l}10 \\
10 \\
10\end{array}$ & & & $\begin{array}{l}1.26(0) \\
1.32(0) \\
1.21(0)\end{array}$ \\
\hline & $\begin{array}{l}11^{b} \\
11\end{array}$ & & & $\begin{array}{l}3.25(-1) \\
3.39(-1)\end{array}$ \\
\hline
\end{tabular}

${ }^{a}$ See Figure 11 for location of capsules.

${ }^{b} \mathrm{Cd}$-covered capsules.

${ }^{c}$ See experimental program plan in Appendix A for description of configurations.

${ }^{d}$ Read: $1.63 \times 10^{-3}$.

${ }^{e}$ Same configuration as IA with voids placed between tanks. 
Table 17. Fast neutron spectrum $(>0.8 \mathrm{MeV}$ ) on centerline at $25 \mathrm{~cm}$ behind the lead slabs (Item IB) Run 7923.A

\begin{tabular}{|c|c|c|c|c|c|}
\hline \multirow[b]{2}{*}{$\begin{array}{c}\text { Neutron } \\
\text { Energy } \\
(\mathrm{MeV})\end{array}$} & \multicolumn{2}{|c|}{ Flux (neutrons $\mathrm{cm}^{-2} \mathrm{MeV}^{-1} \mathrm{~kW}^{-1} \mathrm{~s}^{-1}$ ) } & \multirow[b]{2}{*}{$\begin{array}{c}\text { Neutron } \\
\text { Energy } \\
(\mathrm{MeV}) \\
\end{array}$} & \multicolumn{2}{|c|}{ Flux (neutrons $\mathrm{cm}^{-2} \mathrm{MeV}^{-1} \mathrm{~kW}^{-1} \mathrm{~s}^{-1}$ ) } \\
\hline & $\begin{array}{c}\text { Lower } \\
\text { Limit }\end{array}$ & $\begin{array}{l}\text { Upper } \\
\text { Limit }\end{array}$ & & $\begin{array}{l}\text { Lower } \\
\text { Limit }\end{array}$ & $\begin{array}{l}\text { Upper } \\
\text { Limit }\end{array}$ \\
\hline 8.11E - 01 & $6.65 E+02$ & $6.91 E+02$ & $5.94 \mathrm{E}+00$ & $1.44 \mathrm{E}+01$ & $1.60 \mathrm{E}+01$ \\
\hline $9.07 \mathrm{E}-01$ & $7.63 E+02$ & $7.76 \mathrm{E}+02$ & $6.25 E+00$ & $1.05 \mathrm{E}+01$ & $1.24 \mathrm{E}+01$ \\
\hline $1.01 E+00$ & $7.50 \mathrm{E}+02$ & $7.62 E+02$ & $6.55 E+00$ & $9.02 \mathrm{E}+00$ & $1.06 \mathrm{E}+01$ \\
\hline $1.11 E+00$ & $7.00 \mathrm{E}+02$ & $7.11 E+02$ & $6.84 E+00$ & $8.94 \mathrm{E}+00$ & $1.01 \mathrm{E}+01$ \\
\hline $1.20 \mathrm{E}+00$ & $6.54 \mathrm{E}+02$ & $6.64 E+02$ & $7.24 E+00$ & $8.22 \mathrm{E}+00$ & $9.20 \mathrm{E}+00$ \\
\hline $1.31 \mathrm{E}+00$ & $6.12 E+02$ & $6.22 \mathrm{E}+02$ & $7.74 \mathrm{E}+00$ & $5.56 \mathrm{E}+00$ & $6.76 \mathrm{E}+00$ \\
\hline $1.41 \mathrm{E}+00$ & $5.71 E+02$ & $5.80 \mathrm{E}+02$ & $8.24 \mathrm{E}+00$ & $3.75 E+00$ & $4.97 E+00$ \\
\hline $1.51 E+00$ & $5.25 E+02$ & $5.33 E+02$ & $8.76 E+00$ & $3.47 \mathrm{E}+00$ & $4.16 \mathrm{E}+00$ \\
\hline $1.61 E+00$ & $4.68 \mathrm{E}+02$ & $4.75 E+02$ & $9.26 E+00$ & $2.90 \mathrm{E}+00$ & $3.52 E+00$ \\
\hline $1.71 E+00$ & $4.06 E+02$ & $4.13 E+02$ & $9.74 \mathrm{E}+00$ & $2.41 E+00$ & $2.95 E+00$ \\
\hline $1.81 \mathrm{E}+00$ & $3.49 E+02$ & $3.56 \mathrm{E}+02$ & $1.03 E+01$ & $2.32 \mathrm{E}+00$ & $2.82 \mathrm{E}+00$ \\
\hline $1.93 E+00$ & $2.93 E+02$ & $2.99 E+02$ & $1.08 \mathrm{E}+01$ & $2.24 E+00$ & $2.67 \mathrm{E}+00$ \\
\hline $2.10 \mathrm{E}+00$ & $2.24 E+02$ & $2.30 \mathrm{E}+02$ & $1.12 \mathrm{E}+01$ & $1.89 E+00$ & $2.27 \mathrm{E}+00$ \\
\hline $2.30 \mathrm{E}+00$ & $1.65 E+02$ & $1.70 \mathrm{E}+02$ & $1.18 \mathrm{E}+01$ & $1.32 E+00$ & $1.61 \mathrm{E}+00$ \\
\hline $2.50 \mathrm{E}+00$ & $1.32 E+02$ & $1.36 \mathrm{E}+02$ & $1.24 \mathrm{E}+01$ & $7.29 E-01$ & $9.82 E-01$ \\
\hline $2.70 \mathrm{E}+00$ & $1.11 E+02$ & $1.15 E+02$ & $1.32 \mathrm{E}+01$ & $3.35 \mathrm{E}-01$ & $5.09 \mathrm{E}-01$ \\
\hline $2.90 \mathrm{E}+00$ & $9.71 E+01$ & $1.01 E+02$ & $1.40 \mathrm{E}+01$ & $8.78 \mathrm{E}-02$ & $2.31 E-01$ \\
\hline $3.10 \mathrm{E}+00$ & $8.24 E+01$ & $8.66 \mathrm{E}+01$ & $1.48 \mathrm{E}+01$ & $9.66 \mathrm{E}-02$ & $2.03 E-01$ \\
\hline $3.30 \mathrm{E}+00$ & $6.64 E+01$ & $6.98 \mathrm{E}+01$ & $1.56 E+01$ & $1.05 \mathrm{E}-01$ & $2.08 \mathrm{E}-01$ \\
\hline $3.50 \mathrm{E}+00$ & $5.44 E+01$ & $5.82 E+01$ & $1.65 E+01$ & $3.51 \mathrm{E}-02$ & $1.01 E-01$ \\
\hline $3.71 E+00$ & $4.80 E+01$ & $5.09 E+01$ & $1.75 E+01$ & $-5.39 E-04$ & $4.45 E-02$ \\
\hline $3.91 E+00$ & $4.32 E+01$ & $4.58 \mathrm{E}+01$ & $1.85 E+01$ & $-1.09 \mathrm{E}-02$ & $2.53 E-02$ \\
\hline $4.15 E+00$ & $3.81 E+01$ & $4.05 E+01$ & $1.95 \mathrm{E}+01$ & $-1.88 \mathrm{E}-02$ & $1.38 \mathrm{E}-02$ \\
\hline $4.45 E+00$ & $3.29 E+01$ & $3.49 E+01$ & $2.05 E+01$ & $-2.57 E-02$ & $2.40 \mathrm{E}-02$ \\
\hline $4.75 E+00$ & $2.77 \mathrm{E}+01$ & $2.96 \mathrm{E}+01$ & $2.16 E+01$ & $-2.36 \mathrm{E}-02$ & $2.86 \mathrm{E}-02$ \\
\hline $5.04 \mathrm{E}+00$ & $2.40 E+01$ & $2.57 \mathrm{E}+01$ & $2.26 \mathrm{E}+01$ & $-1.54 \mathrm{E}-02$ & $1.90 E-02$ \\
\hline $5.34 \mathrm{E}+00$ & $2.14 E+01$ & $2.30 E+01$ & $2.35 E+01$ & $-1.52 E-02$ & $1.50 \mathrm{E}-02$ \\
\hline $5.64 \mathrm{E}+00$ & $1.83 E+01$ & $2.01 E+01$ & & & \\
\hline
\end{tabular}

\begin{tabular}{cccc}
$\begin{array}{c}\mathrm{E} 1 \\
(\mathrm{MeV})\end{array}$ & $\begin{array}{c}\mathrm{E} 2 \\
(\mathrm{MeV})\end{array}$ & $\begin{array}{c}\text { Integral } \\
\text { neutrons } \mathrm{cm}^{-2} \mathrm{~kW}^{-1} \mathrm{~s}^{-1}\end{array}$ & $\begin{array}{c}\text { Error } \\
\text { neutrons cm } \mathrm{kW}^{-1} \mathrm{~s}^{-1}\end{array}$ \\
\hline 0.811 & 1.000 & $1.42 \mathrm{E}+02$ & $1.45 \mathrm{E}+00$ \\
1.000 & 1.200 & $1.42 \mathrm{E}+02$ & $1.07 \mathrm{E}+00$ \\
1.200 & 1.600 & $2.31 \mathrm{E}+02$ & $1.76 \mathrm{E}+00$ \\
1.600 & 2.000 & $1.45 \mathrm{E}+02$ & $1.28 \mathrm{E}+00$ \\
2.000 & 3.000 & $1.48 \mathrm{E}+02$ & $2.32 \mathrm{E}+00$ \\
3.000 & 4.000 & $6.06 \mathrm{E}+01$ & $1.67 \mathrm{E}+00$ \\
4.000 & 6.000 & $5.36 \mathrm{E}+01$ & $1.88 \mathrm{E}+00$ \\
6.000 & 8.000 & $1.81 \mathrm{E}+01$ & $1.33 \mathrm{E}+00$ \\
8.000 & 10.000 & $7.10 \mathrm{E}+00$ & $7.56 \mathrm{E}-01$ \\
10.000 & 12.000 & $4.29 \mathrm{E}+00$ & $4.00 \mathrm{E}-01$ \\
12.000 & 16.000 & $1.42 \mathrm{E}+00$ & $3.10 \mathrm{E}-01$ \\
16.000 & 20.000 & $1.03 \mathrm{E}-01$ & $9.22 \mathrm{E}-02$ \\
3.000 & 10.000 & $1.39 \mathrm{E}+02$ & $5.65 \mathrm{E}+00$ \\
1.500 & 15.000 & $4.89 \mathrm{E}+02$ & $1.03 \mathrm{E}+01$ \\
3.000 & 12.000 & $1.43 \mathrm{E}+02$ & $6.05 \mathrm{E}+00$ \\
\hline
\end{tabular}


Table 18. Neutron spectrum ( $50 \mathrm{keV}$ to $1.4 \mathrm{MeV}$ ) on centerline at $25 \mathrm{~cm}$ behind the lead slabs (Item VB) Runs 1593.C, 1593.A, 1593.B

\begin{tabular}{|c|c|c|c|c|}
\hline $\mathrm{N}$ & \multicolumn{2}{|c|}{$\begin{array}{l}\text { Energy Boundary } \\
(\mathrm{MeV})\end{array}$} & $\begin{array}{c}\text { Flux } \\
\text { (neutrons } \mathrm{cm}^{-2} \mathrm{MeV}^{-1} \mathrm{~kW}^{-1} \mathrm{~s}^{-1} \text { ) }\end{array}$ & $\begin{array}{l}\text { Error } \\
(\%)\end{array}$ \\
\hline \multicolumn{5}{|c|}{ RUN 1593.C } \\
\hline 1 & 0.0389 & 0.0455 & $6.85 E+04$ & 2.19 \\
\hline 2 & 0.0455 & 0.0538 & $5.19 E+04$ & 2.48 \\
\hline 3 & 0.0538 & 0.0637 & $4.94 E+04$ & 2.32 \\
\hline 4 & 0.0637 & 0.0737 & $4.86 E+04$ & 2.52 \\
\hline 5 & 0.0737 & 0.0869 & $3.53 E+04$ & 2.63 \\
\hline 6 & 0.0869 & 0.1034 & $2.22 E+04$ & 3.47 \\
\hline 7 & 0.1034 & 0.1200 & $2.22 E+04$ & 3.83 \\
\hline 8 & 0.1200 & 0.1415 & $1.90 E+04$ & 3.47 \\
\hline 9 & 0.1415 & 0.1680 & $1.27 E+04$ & 4.32 \\
\hline \multicolumn{5}{|c|}{$\underline{\text { RUN 1593.A }}$} \\
\hline 1 & 0.1191 & 0.1436 & $1.93 E+04$ & 1.13 \\
\hline 2 & 0.1436 & 0.1680 & $1.34 \mathrm{E}+04$ & 1.77 \\
\hline 3 & 0.1680 & 0.1985 & $1.01 E+04$ & 2.03 \\
\hline 4 & 0.1985 & 0.2352 & $8.16 E+03$ & 2.29 \\
\hline 5 & 0.2352 & 0.2718 & $8.78 \mathrm{E}+03$ & 2.32 \\
\hline 6 & 0.2718 & 0.3207 & $7.52 E+03$ & 2.07 \\
\hline 7 & 0.3207 & 0.3818 & $4.28 E+03$ & 2.98 \\
\hline 8 & 0.3818 & 0.4490 & $3.12 E+03$ & 4.02 \\
\hline 9 & 0.4490 & 0.5284 & $2.60 E+03$ & 4.27 \\
\hline \multicolumn{5}{|c|}{ RUN 1593.B } \\
\hline 1 & 0.3759 & 0.4521 & $3.03 E+03$ & 1.95 \\
\hline 2 & 0.4521 & 0.5284 & $2.81 E+03$ & 2.24 \\
\hline 3 & 0.5284 & 0.6156 & $1.74 E+03$ & 3.24 \\
\hline 4 & 0.6156 & 0.7245 & $8.33 E+02$ & 5.74 \\
\hline 5 & 0.7245 & 0.8553 & $8.02 E+02$ & 5.46 \\
\hline 6 & 0.8553 & 1.0078 & $7.34 E+02$ & 5.56 \\
\hline 7 & 1.0078 & 1.1821 & $6.46 E+02$ & 5.88 \\
\hline 8 & 1.1821 & 1.4000 & $6.00 E+02$ & 5.07 \\
\hline
\end{tabular}


Table 19. Bonner ball measurements on centerline at NE-213 location behind spectrum modifier (Item IB)

\begin{tabular}{|c|c|c|c|c|c|c|}
\hline \multirow[b]{3}{*}{$\underline{\text { Configuration }}^{a}$} & \multicolumn{6}{|c|}{ Bonner ball count rates $\left(\mathrm{s}^{-1} \mathrm{~W}^{-1}\right)$} \\
\hline & \multicolumn{2}{|c|}{ 3-inch-Diam Ball } & \multicolumn{2}{|c|}{ 5-inch-Diam Ball } & \multicolumn{2}{|c|}{ 10-inch-Diam Ball } \\
\hline & $\underline{\text { Foreground }}^{d}$ & Background & Foreground & Background & Foreground & $\underline{\text { Background }}$ \\
\hline Item $\mathrm{IB}^{b, c}$ & $1.33(2)^{e}$ & & $1.91(2)$ & & $2.73(1)$ & \\
\hline
\end{tabular}

${ }^{a}$ See experimental program plan in Appendix A for description of configurations.

${ }^{b}$ Lead slab $(7.62 \mathrm{~cm})$ between configuration and detector (see Figure 4).

${ }^{c}$ Detectors at $25 \mathrm{~cm}$ behind the lead.

${ }^{d}$ Count rates without shadow shield between detector and configuration.

${ }^{e}$ Read: $1.33 \times 10^{2}$. 
Table 20. 5-inch Bonner ball horizontal traverse through midplane at $30 \mathrm{~cm}$ behind spectrum modifier

(Item IB)

\begin{tabular}{|c|c|}
\hline & $\begin{array}{l}\text { Bonner ball count rate } \\
\qquad\left(\mathrm{s}^{-1} \mathrm{~W}^{-1}\right)\end{array}$ \\
\hline $\begin{array}{l}\text { Distance from } \\
\text { centerline }(\mathrm{cm})\end{array}$ & $\underline{\text { Item IB }}^{a}$ \\
\hline $195 \mathrm{~S}$ & $5.89(1)^{b}$ \\
\hline 180 & $8.36(1)$ \\
\hline 150 & $1.21(2)$ \\
\hline 120 & $1.82(2)$ \\
\hline 90 & $2.40(2)$ \\
\hline 75 & $2.71(2)$ \\
\hline 60 & $2.96(2)$ \\
\hline 45 & $3.14(2)$ \\
\hline 30 & $3.30(2)$ \\
\hline 15 & $3.38(2)$ \\
\hline 0 & $3.44(2)$ \\
\hline $0^{c}$ & $3.49(2)$ \\
\hline 15 & $3.49(2)$ \\
\hline 30 & $3.29(2)$ \\
\hline 45 & $3.20(2)$ \\
\hline 60 & $2.98(2)$ \\
\hline 75 & $2.58(2)$ \\
\hline 90 & $2.34(2)$ \\
\hline 120 & $1.72(2)$ \\
\hline 150 & $1.15(2)$ \\
\hline 180 & $7.68(1)$ \\
\hline $195 \mathrm{~N}$ & $5.35(1)$ \\
\hline
\end{tabular}

${ }^{a}$ See experimental program plan in Appendix A for description of configuration.

${ }^{b}$ Read: $5.89 \times 10^{1}$.

${ }^{c}$ Repeat. 
Table 21. Bare Bonner ball measurements on centerline at $30 \mathrm{~cm}$ behind a series of configurations

\begin{tabular}{|c|c|c|c|c|c|c|c|c|}
\hline \multirow[b]{2}{*}{$\underline{\text { Detection Modes }}^{a}$} & \multicolumn{8}{|c|}{ count rate $\left(s^{-1} W^{-1}\right)$} \\
\hline & $\underline{\text { Item IIC }}^{b}$ & Item IID & Item IIE & Item IIF & Item IIIA & Item IIIC & Item IIID & Item IIIE \\
\hline inside $\mathrm{Cd}$ hut & $2.15(-4)^{c}$ & $1.47(-4)$ & $7.92(-5)$ & $4.12(-5)$ & $6.91(-1)$ & $1.51(-3)$ & $7.25(-4)$ & $1.01(-3)$ \\
\hline $\begin{array}{l}\text { Cd sheet over face of } \\
\text { mockup }\end{array}$ & $6.86(-4)$ & $5.79(-4)$ & $1.84(-4)$ & $1.17(-4)$ & & & & \\
\hline $\begin{array}{l}\text { Cd sheet behind } \\
\text { detector }\end{array}$ & & & & & & & & \\
\hline
\end{tabular}

Table 21. (continued)

\begin{tabular}{ccccccccc}
\hline & \multicolumn{7}{c}{ count rate $\left(\mathrm{s}^{-1} \mathrm{~W}^{-1}\right)$} \\
\cline { 2 - 8 } Detection Modes & $\underline{\text { Item IVA }}$ & $\underline{\text { Item IVB }}$ & $\underline{\text { Item IVC }}$ & $\underline{\text { Item IVD }}$ & $\underline{\text { Item IVE }}$ & $\underline{\text { Item VD }}$ & $\underline{\text { Item VE }}$ & $\underline{\text { Item VIC }}$ \\
inside Cd hut & $1.05(-2)$ & $5.19(-3)$ & $3.94(-3)$ & $2.29(-3)$ & $6.01(-4)$ & & \\
$\begin{array}{c}\text { Cd sheet over face of } \\
\text { mockup }\end{array}$ & $2.81(-2)$ & $1.61(-2)$ & $9.22(-3)$ & $3.67(-3)$ & $9.68(-4)$ & & \\
$\begin{array}{c}\text { Cd sheet behind } \\
\text { detector }\end{array}$ & & & & & & $3.50(0)$ & $1.27(0)$ & $7.59(-1)$ \\
\hline
\end{tabular}

Table 21. (continued)

\begin{tabular}{ccccccc}
\hline & \multicolumn{5}{c}{ count rate $\left(\mathrm{s}^{-1} \mathrm{~W}^{-1)}\right.$} \\
\cline { 2 - 6 } Detection Modes & $\underline{\text { Item VIE }}$ & $\underline{\text { Item VIIA }}$ & $\underline{\text { Item VIIB }}$ & $\underline{\text { Item VIID }}$ & $\underline{\text { Item VIIE }}$ & $\underline{\text { Item VIIF }}$ \\
$\begin{array}{c}\text { Cd sheet above detector } \\
\text { Cd sheet behind detector }\end{array}$ & $1.04(-1)$ & $4.97(1)$ & $2.34(-1)$ & & & \\
\hline
\end{tabular}


Table 21. (continued)

\begin{tabular}{|c|c|c|c|c|c|c|c|c|}
\hline \multirow[b]{2}{*}{ Detection Modes } & \multicolumn{8}{|c|}{ count rate $\left(\mathrm{s}^{-1} \mathrm{~W}^{-1}\right)$} \\
\hline & $\underline{\text { Item VIIID }}$ & $\underline{\text { Item VIIIE }}$ & $\underline{\text { Item VIIIF }}$ & $\underline{\text { Item IXA }}$ & Item IXB & Item IXC & Item IXD & Item IXE \\
\hline $\begin{array}{l}\mathrm{Cd} \text { sheet behind } \\
\text { detector }\end{array}$ & $4.36(-2)$ & $2.53(-2)$ & $2.62(-2)$ & & $1.95(-1)$ & $7.41(-2)$ & $3.04(-2)$ & $1.75(-2)$ \\
\hline $\begin{array}{c}\text { Cd sheet above } \\
\text { detector }\end{array}$ & & & & & $1.57(-1)$ & $6.46(-2)$ & & \\
\hline see footnote (1) & & & & $1.29(0)$ & & & & \\
\hline see footnote (2) & & & & $9.86(-1)$ & & & & \\
\hline see footnote (3) & & & & $1.24(0)$ & & & & \\
\hline see footnote (4) & & & & $9.15(-1)$ & & & & \\
\hline see footnote (5) & & & & $6.41(-1)$ & & & & \\
\hline see footnote (6) & & & & $1.24(-1)$ & & & & \\
\hline see footnote (7) & & & & $4.17(-2)$ & & & & \\
\hline
\end{tabular}


Table 21. (continued)

\begin{tabular}{cccccc}
\hline & \multicolumn{3}{c}{ count rate $\left(\mathrm{s}^{-1} \mathrm{~W}^{-1}\right)$} \\
\cline { 2 - 6 } Detection Modes & $\underline{\text { Item XA }}$ & $\underline{\text { Item XB }}$ & $\underline{\text { Item XC }}$ & $\underline{\text { Item XD }}$ & $\underline{\text { Item XE }}$ \\
Cd sheet behind detector & & & & & \\
Cd sheet above detector & $1.45(1)$ & $5.36(0)$ & $2.17(0)$ & & $3.12(-1)$ \\
Cd sheet above and below detector & & $5.04(0)$ & & \\
\hline
\end{tabular}

${ }^{a, b}$ See experimental program plan in Appendix A for description of configurations.

${ }^{c}$ Read: $2.15 \times 10^{-4}$.

${ }^{1} \mathrm{Cd}$ covering face of Li-Par above the front $\mathrm{B}_{4} \mathrm{C}$ slab $(6 \mathrm{~W})$.

${ }^{2} \mathrm{Cd}$ covering face of $\mathrm{Li}$-Par above the front $\mathrm{B}_{4} \mathrm{C}$ slab $(6 \mathrm{~W})$ plus $\mathrm{Cd}$ sheet beneath concrete slab covering top of the mockup.

${ }^{3} \mathrm{Cd}$ covering face of $\mathrm{Li}$-Par above the front $\mathrm{B}_{4} \mathrm{C}$ slab $(6 \mathrm{~W})$ and the $\mathrm{Li}$-Par above both side $\mathrm{B}_{4} \mathrm{C}$ slabs $(7 \mathrm{~W}$ and $8 \mathrm{~W})$.

${ }^{4} \mathrm{Cd}$ covering face of $\mathrm{Li}$-Par above the front $\mathrm{B}_{4} \mathrm{C}$ slab (6W) and the two side $\mathrm{B}_{4} \mathrm{C}$ slabs ( $7 \mathrm{~W}$ and $8 \mathrm{~W}$ ), plus $\mathrm{Cd}$ over the aluminum plug insert.

${ }^{5} \mathrm{Cd}$ covering face of $\mathrm{Li}-\mathrm{Par}$ above the front $\mathrm{B}_{4} \mathrm{C}$ slab $(6 \mathrm{~W})$ and the two side $\mathrm{B}_{4} \mathrm{C}$ slabs ( $7 \mathrm{~W}$ and $8 \mathrm{~W}$ ), Cd over the aluminum insert and beneath the concrete slab covering the top of the mockup.

${ }^{6} \mathrm{Cd}$ covering face of $\mathrm{Li}-\mathrm{Par}$ above the front $\mathrm{B}_{4} \mathrm{C}$ slab $(6 \mathrm{~W})$ and the two side $\mathrm{B}_{4} \mathrm{C}$ slabs $(7 \mathrm{~W}$ and $8 \mathrm{~W}$ ), $\mathrm{Cd}$ over the aluminum insert and beneath the concrete slab covering the top of the mockup, $10.2 \mathrm{~cm}$ of $\mathrm{Li}$-Par covering the face of the front $\mathrm{B}_{4} \mathrm{C}$ slab (6W).

${ }^{7} \mathrm{Cd}$-covered detector, $\mathrm{Cd}$ covering face of $\mathrm{Li}$-Par above the front $\mathrm{B}_{4} \mathrm{C}$ slab $(6 \mathrm{~W})$ and the two side $\mathrm{B}_{4} \mathrm{C}$ slabs $(7 \mathrm{~W}$ and $8 \mathrm{~W}), \mathrm{Cd}$ over the aluminum insert and beneath the concrete slab covering the top of the mockup, $10.2 \mathrm{~cm}$ of Li-Par covering the face of the front $\mathrm{B}_{4} \mathrm{C}$ slab $(6 \mathrm{~W})$. 
Table 22. Bare Bonner ball measurements on centerline at $150 \mathrm{~cm}$ behind a series of configurations

\begin{tabular}{|c|c|c|c|c|c|c|c|c|c|c|c|c|}
\hline \multirow[b]{3}{*}{ Detection Modes $^{a}$} & \multicolumn{12}{|c|}{ count rate $\left(\mathrm{s}^{-1} \mathrm{~W}^{-1}\right)$} \\
\hline & \multicolumn{2}{|c|}{$\underline{\text { Item IIB }}^{b}$} & \multicolumn{2}{|c|}{ Item IIC } & \multicolumn{2}{|c|}{ Item IID } & \multicolumn{2}{|c|}{ Item IIE } & \multicolumn{2}{|c|}{$\underline{\text { Item IIF }}$} & \multicolumn{2}{|c|}{ Item IVA } \\
\hline & Foreground & Background & Foreground & Background & Foreground & Background & Foreground & Background & Foreground & Background & Foreground & Background \\
\hline $\begin{array}{l}\text { Cd over face of } \\
\text { mockup }\end{array}$ & $1.24(-3)^{e}$ & & $1.07(-3)$ & & $1.07(-3)$ & & $2.20(-4)$ & & $1.44(-4)$ & & $2.92(-2)$ & , \\
\hline \multicolumn{13}{|l|}{$\begin{array}{l}\text { Cd sheet behind } \\
\text { detector }\end{array}$} \\
\hline $\begin{array}{l}\text { Cd sheet over face of } \\
\text { shadow shield }\end{array}$ & & & & & & & & & & & & \\
\hline
\end{tabular}

Table 22. (continued)

\begin{tabular}{|c|c|c|c|c|c|c|c|c|c|c|c|}
\hline \multirow[b]{3}{*}{ Detection Modes } & \multicolumn{11}{|c|}{ count rate $\left(\mathrm{s}^{-1} \mathrm{~W}^{-1}\right)$} \\
\hline & \multicolumn{2}{|c|}{ Item IVB } & \multicolumn{2}{|c|}{ Item IVC } & \multicolumn{2}{|c|}{ Item IVD } & \multicolumn{2}{|c|}{$\underline{\text { Item IVE }}$} & \multicolumn{2}{|c|}{ Item VIIA } & Item VIIB \\
\hline & Foreground & Background & Foreground & Background & Foreground & Background & Foreground & Background & Foreground & Background & Foreground \\
\hline $\begin{array}{l}\mathrm{Cd} \text { over face of } \\
\text { mockup }\end{array}$ & $1.55(-2)$ & & $8.27(-3)$ & & $3.13(-3)$ & & $8.31(-4)$ & & & & \\
\hline $\begin{array}{l}\text { Cd sheet behind } \\
\text { detector }\end{array}$ & & & & & & & & & $2.59(1)$ & & $5.85(-1)$ \\
\hline $\begin{array}{l}\mathrm{Cd} \text { sheet above } \\
\text { detector }\end{array}$ & & & & & & & & & $1.82(1)$ & & $2.22(-1)$ \\
\hline $\begin{array}{l}\text { Cd sheet above } \\
\text { detector with Cd sheet } \\
\text { behind detector }\end{array}$ & & & & & & & & & & & $1.93(-1)$ \\
\hline
\end{tabular}


Table 22. (continued)

\begin{tabular}{|c|c|c|c|c|c|c|c|c|c|c|c|c|}
\hline \multirow[b]{3}{*}{ Detection Modes } & \multicolumn{12}{|c|}{ count rate $\left(\mathrm{s}^{-1} \mathrm{~W}^{-1}\right)$} \\
\hline & \multicolumn{2}{|c|}{ Item VIIC } & \multicolumn{2}{|c|}{ Item VIID } & \multicolumn{2}{|c|}{ Item VIIE } & \multicolumn{2}{|c|}{$\underline{\text { Item VIIF }}$} & \multicolumn{2}{|c|}{$\underline{\text { Item VIIIC }}$} & \multicolumn{2}{|c|}{ Item VIIID } \\
\hline & Foreground & Background & Forepround & Background & Foreground & Background & Foreground & Backpround & Foreground & Background & Foreground & Background \\
\hline $\begin{array}{c}\mathrm{Cd} \text { over face of } \\
\text { mockup }\end{array}$ & & & & & & & & & & & & \\
\hline $\begin{array}{l}\text { Cd sheet behind } \\
\text { detector }\end{array}$ & $1.14(-1)$ & & $5.44(-2)$ & & $2.69(-2)$ & & $1.45(-2)$ & & $5.55(-2)$ & & $2.23(-2)$ & \\
\hline \multirow[t]{4}{*}{$\begin{array}{c}\text { Cd sheet over face of } \\
\text { shadow shield } \\
\end{array}$} & & & & $2.96(-2)$ & & $2.91(-2)$ & & $2.81(-2)$ & & & & \\
\hline & \multicolumn{10}{|c|}{ Table 22. (continued) } & & \\
\hline & \multicolumn{12}{|c|}{ count rate $\left(\mathrm{s}^{-1} \mathrm{~W}^{-1}\right)$} \\
\hline & \multicolumn{2}{|c|}{ Item VIIIE } & \multicolumn{2}{|c|}{$\underline{\text { Item VIIIF }}$} & \multicolumn{2}{|c|}{ Item IXA } & \multicolumn{2}{|c|}{ Item IXB } & \multicolumn{2}{|c|}{$\underline{\text { Item IXC }}$} & \multicolumn{2}{|c|}{$\underline{\text { Item IXD }}$} \\
\hline Detection Modes & Foreground & Background & Foreground & Background & Foreground & Background & Foreground & Background & Forepround & Background & Foreground & Backpround \\
\hline $\begin{array}{l}\text { Cd sheet behind } \\
\text { detector }\end{array}$ & & & $8.87(-3)$ & & $4.80(-1)$ & & $6.80(-2)$ & & $2.79(-2)$ & & $2.33(-2)$ & \\
\hline $\begin{array}{l}\text { Cd sheet over face of } \\
\text { shadow shield }\end{array}$ & & $3.04(-2)$ & & $2.79(-2)$ & & & & & & $2.41(-2)$ & & $2.46(-2)$ \\
\hline $\begin{array}{l}\mathrm{Cd} \text { sheet above } \\
\text { detector }\end{array}$ & & & & & & & $6.09(-2)$ & & $3.89(-2)$ & & & \\
\hline See footnote (1) & & & & & $3.55(-1)$ & & & & & & & \\
\hline See footnote (2) & & & & & $1.74(-1)$ & & & & & & & \\
\hline See footnote (3) & & & & & $3.29(-1)$ & & & & & & & \\
\hline See footnote (4) & & & & & $3.04(-1)$ & & & & & & & \\
\hline See footnote (5) & & & & & $1.39(-1)$ & & & & & & & \\
\hline See footnote (6) & & & & & $6.33(-2)$ & & & & & & & \\
\hline See footnote $(7)$ & & & & & $2.66(-2)$ & & & & & & & \\
\hline
\end{tabular}


Table 22. (continued)

\begin{tabular}{|c|c|c|c|c|c|c|c|c|c|c|c|c|}
\hline \multirow[b]{3}{*}{ Detection Modes } & \multicolumn{12}{|c|}{ count rate $\left(\mathrm{s}^{-1} \mathrm{~W}^{-1}\right)$} \\
\hline & \multicolumn{2}{|c|}{ Item IXE } & \multicolumn{2}{|c|}{ Item XA } & \multicolumn{2}{|c|}{ Item XB } & \multicolumn{2}{|c|}{ Item XC } & \multicolumn{2}{|c|}{ Item XD } & \multicolumn{2}{|c|}{ Item XE } \\
\hline & Foreground & Background & Foreground & Background & Foreground & Background & Foreground & Background & Foreground & Background & Foreground & Background \\
\hline $\begin{array}{l}\mathrm{Cd} \text { sheet behind } \\
\text { detector }\end{array}$ & $1.93(-2)$ & & $6.59(0)$ & & $1.98(0)$ & & $6.77(-1)$ & & & & & \\
\hline $\begin{array}{l}\text { Cd sheet over face of } \\
\text { shadow shield }\end{array}$ & & $2.74(-2)$ & & & & & & $9.62(-2)$ & & $5.72(-2)$ & & $3.96(-2)$ \\
\hline $\begin{array}{l}\text { Cd sheet above } \\
\text { detector }\end{array}$ & & & $4.68(0)$ & & $1.66(0)$ & & $7.10(-1)$ & & & & & \\
\hline $\begin{array}{l}\mathrm{Cd} \text { sheet above and } \\
\text { below detector }\end{array}$ & & & & & $1.49(0)$ & & & & & & & \\
\hline
\end{tabular}

${ }^{a}$ See experimental program plan in Appendix A for description of configurations.

${ }^{b}$ See experimental program plan in Appendix A for description of configurations.

${ }^{c}$ Count rates without shadow shield between detector and configuration.

${ }^{d}$ Count rates with shadow shield between detector and configuration.

${ }^{e}$ Read: $1.24 \times 10^{-3}$.

${ }^{1} \mathrm{Cd}$ covering face of $\mathrm{Li}-\mathrm{Par}$ above the front $\mathrm{B}_{4} \mathrm{C}$ slab $(6 \mathrm{~W})$.

${ }^{2} \mathrm{Cd}$ covering face of $\mathrm{Li}-\mathrm{Par}$ above the front $\mathrm{B}_{4} \mathrm{C}$ slab $(6 \mathrm{~W})$ plus $\mathrm{Cd}$ sheet beneath concrete slab covering top of the mockup.

${ }^{3} \mathrm{Cd}$ covering face of $\mathrm{Li}$-Par above the front $\mathrm{B}_{4} \mathrm{C}$ slab $(6 \mathrm{~W})$ and the $\mathrm{Li}$-Par above both side $\mathrm{B}_{4} \mathrm{C}$ slabs $(7 \mathrm{~W}$ and $8 \mathrm{~W})$.

${ }^{4} \mathrm{Cd}$ covering face of $\mathrm{Li}-\mathrm{Par}$ above the front $\mathrm{B}_{4} \mathrm{C}$ slab $(6 \mathrm{~W})$ and the two side $\mathrm{B}_{4} \mathrm{C}$ slabs $(7 \mathrm{~W}$ and $8 \mathrm{~W})$, plus $\mathrm{Cd}$ over the aluminum plug insert.

${ }^{5} \mathrm{Cd}$ covering face of $\mathrm{Li}-\mathrm{Par}$ above the front $\mathrm{B}_{4} \mathrm{C}$ slab $(6 \mathrm{~W})$ and the two side $\mathrm{B}_{4} \mathrm{C}$ slabs $(7 \mathrm{~W}$ and $8 \mathrm{~W})$, Cd over the aluminum insert and beneath the concrete slab covering the top of the mockup.

${ }^{6} \mathrm{Cd}$ covering face of $\mathrm{Li}-\mathrm{Par}$ above the front $\mathrm{B}_{4} \mathrm{C}$ slab $(6 \mathrm{~W})$ and the two side $\mathrm{B}_{4} \mathrm{C}$ slabs $(7 \mathrm{~W}$ and $8 \mathrm{~W})$, Cd over the aluminum insert and beneath the concrete slab covering the top of the mockup, $10.2 \mathrm{~cm}$ of Li-Par covering the face of the front $\mathrm{B}_{4} \mathrm{C}$ slab (6W).

${ }^{7} \mathrm{Cd}$-covered detector, $\mathrm{Cd}$ covering face of $\mathrm{Li}$-Par above the front $\mathrm{B}_{4} \mathrm{C}$ slab $(6 \mathrm{~W})$ and the two side $\mathrm{B}_{4} \mathrm{C}$ slabs $(7 \mathrm{~W}$ and $8 \mathrm{~W})$, $\mathrm{Cd}$ over the aluminum insert and beneath the concrete slab covering the top of the mockup, $10.2 \mathrm{~cm}$ of Li-Par covering the face of the front $\mathrm{B}_{4} \mathrm{C}$ slab $(6 \mathrm{~W})$. 
Table 23. Sodium foil measurements in voids located throughout configuration mockups

\begin{tabular}{|c|c|c|c|c|c|c|c|}
\hline \multicolumn{2}{|c|}{$\underline{\text { Foil Location }}^{a}$} & \multicolumn{6}{|c|}{$\mathrm{S}(\mathrm{nCi}) / \mathrm{kW} / \mathrm{g}(\mathrm{Na}) /$ minute of exposure) } \\
\hline Void & Position & $\underline{\text { Item } \mathrm{VE}^{b}}$ & Item VIE & Item VIIF & Item VIIIF & $\underline{\text { Item IX }}$ & Item X \\
\hline \multirow[t]{6}{*}{1} & A & $2.39(-2)^{c}$ & $2.04(-2)$ & $1.86(-2)$ & $1.94(-2)$ & $1.55(-2)$ & $1.62(-2)$ \\
\hline & B & $2.58(-2)$ & $2.22(-2)$ & $2.17(-2)$ & $2.13(-2)$ & $1.72(-2)$ & $2.04(-2)$ \\
\hline & $\mathrm{C}$ & $2.40(-2)$ & $2.02(-2)$ & $1.98(-2)$ & $1.89(-2)$ & $1.66(-2)$ & $2.36(-2)$ \\
\hline & D & $2.55(-2)$ & $2.21(-2)$ & $2.03(-2)$ & $2.05(-2)$ & $1.73(-2)$ & $1.75(-2)$ \\
\hline & $\mathrm{E}$ & $2.78(-2)$ & $2.32(-2)$ & $2.33(-2)$ & $2.37(-2)$ & $1.86(-2)$ & $2.27(-2)$ \\
\hline & F & $2.54(-2)$ & $2.14(-2)$ & $2.18(-2)$ & $2.05(-2)$ & $1.54(-2)$ & $2.30(-2)$ \\
\hline \multirow[t]{6}{*}{2} & A & & $1.01(-3)$ & & & & $8.33(-4)$ \\
\hline & B & & $4.64(-4)$ & & & & $6.54(-3)$ \\
\hline & $\mathrm{C}$ & & $8.18(-4)$ & & & & $1.31(-2)$ \\
\hline & D & & $9.69(-4)$ & & & & $4.42(-4)$ \\
\hline & $\mathrm{E}$ & & $4.11(-4)$ & & & & $5.24(-3)$ \\
\hline & $\mathrm{F}$ & & $7.52(-4)$ & & & & $1.52(-2)$ \\
\hline \multirow[t]{6}{*}{3} & A & $1.08(-2)$ & $9.04(-4)$ & $7.64(-5)$ & $5.67(-5)$ & $5.86(-5)$ & $1.12(-3)$ \\
\hline & B & $1.20(-2)$ & $4.33(-4)$ & $5.77(-5)$ & $5.58(-5)$ & $6.09(-5)$ & $3.16(-3)$ \\
\hline & $\mathrm{C}$ & $1.11(-2)$ & $7.25(-4)$ & $7.32(-5)$ & $6.31(-5)$ & $5.33(-5)$ & $4.31(-3)$ \\
\hline & D & $1.14(-2)$ & $9.91(-4)$ & $5.75(-5)$ & $4.35(-5)$ & $6.17(-5)$ & $1.24(-3)$ \\
\hline & E & $1.31(-2)$ & $4.42(-4)$ & $4.03(-5)$ & $3.06(-5)$ & $1.21(-4)$ & $3.63(-3)$ \\
\hline & $\mathrm{F}$ & $1.18(-2)$ & $7.97(-4)$ & $4.14(-5)$ & $3.94(-5)$ & $5.45(-5)$ & $5.22(-3)$ \\
\hline \multirow[t]{6}{*}{4} & A & $4.48(-3)$ & $4.16(-4)$ & $5.87(-5)$ & $2.28(-5)$ & $2.94(-5)$ & $7.39(-4)$ \\
\hline & B & $4.87(-3)$ & $2.76(-4)$ & $3.86(-5)$ & $2.56(-5)$ & $3.10(-5)$ & $1.40(-3)$ \\
\hline & $\mathrm{C}$ & $4.48(-3)$ & $3.46(-4)$ & $5.04(-5)$ & $2.74(-5)$ & $2.48(-5)$ & $1.57(-3)$ \\
\hline & D & $4.79(-3)$ & $4.27(-4)$ & $5.59(-5)$ & $1.93(-5)$ & $2.99(-5)$ & $7.97(-4)$ \\
\hline & $\mathbf{E}$ & $5.38(-3)$ & $2.85(-4)$ & $3.38(-5)$ & $2.03(-5)$ & $3.67(-5)$ & $1.57(-3)$ \\
\hline & $\mathrm{F}$ & $4.81(-3)$ & $4.09(-4)$ & $4.64(-5)$ & $1.98(-5)$ & $2.47(-5)$ & $1.70(-3)$ \\
\hline \multirow[t]{6}{*}{5} & A & $1.65(-3)$ & $1.49(-4)$ & $2.93(-5)$ & $1.09(5)$ & $1.26(5)$ & $2.99(-4)$ \\
\hline & B & $1.93(-3)$ & $1.28(-4)$ & $2.23(-5)$ & $1.26(-5)$ & $1.48(-5)$ & $4.66(-4)$ \\
\hline & $\mathrm{C}$ & $1.77(-3)$ & $1.12(-4)$ & $2.50(-5)$ & $1.14(-5)$ & $1.14(-5)$ & $4.95(-4)$ \\
\hline & D & $1.79(-3)$ & $1.62(-4)$ & $3.02(-5)$ & $8.09(-6)$ & $1.26(5)$ & $3.25(-4)$ \\
\hline & E & $1.91(-3)$ & $1.40(-4)$ & $2.00(-5)$ & $1.12(-5)$ & $1.51(-5)$ & $5.31(-4)$ \\
\hline & F & $1.83(-3)$ & $1.45(-4)$ & $2.34(-5)$ & $9.56(-6)$ & $1.07(-5)$ & $5.33(-4)$ \\
\hline \multirow[t]{6}{*}{6} & A & $3.15(-4)$ & $4.26(-5)$ & $9.20(-6)$ & $4.38(-6)$ & $5.36(-6)$ & $5.61(-5)$ \\
\hline & B & $3.83(-4)$ & $3.45(-5)$ & $7.93(-6)$ & $6.15(-6)$ & $5.81(-6)$ & $8.94(-5)$ \\
\hline & $\mathrm{C}$ & $3.14(-4)$ & $3.37(-5)$ & $8.63(-6)$ & $4.45(-6)$ & $5.21(-6)$ & $8.75(-5)$ \\
\hline & $\mathrm{D}$ & $3.22(-4)$ & $3.62(-5)$ & $8.89(-6)$ & $5.23(-6)$ & $5.19(-6)$ & $5.64(-5)$ \\
\hline & E & $3.69(-4)$ & $5.48(-5)$ & $7.73(-6)$ & $5.07(-6)$ & $5.42(-6)$ & $9.32(-5)$ \\
\hline & $\mathbf{F}$ & $3.17(-4)$ & $3.48(-5)$ & $8.64(-6)$ & $3.82(-6)$ & $5.25(-6)$ & $9.02(-5)$ \\
\hline
\end{tabular}

${ }^{a}$ See Figure 11 for location of capsules.

${ }^{b}$ See experimental program plan in Appendix A for description of configurations.

${ }^{c}$ Read $2.39 \times 10^{-2}$. 
Table 24. Bonner ball horizontal traverses through midplane at $30 \mathrm{~cm}$ behind the shield mockup (Item XE) ${ }^{a}$

\begin{tabular}{|c|c|c|c|c|c|}
\hline \multirow[b]{2}{*}{$\begin{array}{l}\text { Distance from } \\
\text { centerline }(\mathrm{cm})\end{array}$} & \multicolumn{5}{|c|}{ Bonner ball count rates $\left(\mathrm{s}^{-1} \mathrm{~W}^{-1}\right)$} \\
\hline & Bare Ball & $\begin{array}{c}\text { Cd-covered } \\
\text { Ball } \\
\end{array}$ & $\begin{array}{c}\begin{array}{c}\text { 3-inch-Diam } \\
\text { Ball }\end{array} \\
\end{array}$ & $\begin{array}{c}\text { 5-inch-Diam } \\
\text { Ball } \\
\end{array}$ & $\begin{array}{c}\text { 10-inch-Diam } \\
\text { Ball }\end{array}$ \\
\hline $186 \mathrm{~N}$ & & & $4.73(-2)$ & $6.28(-2)$ & \\
\hline 176 & & & $5.87(-2)$ & $7.68(-2)$ & \\
\hline 166 & & & $7.85(-2)$ & $1.04(-1)$ & \\
\hline 156 & & & $1.08(-1)$ & $1.36(-1)$ & $1.60(-2)$ \\
\hline 146 & & & $1.35(-1)$ & $1.66(-1)$ & $2.04(-2)$ \\
\hline 136 & & & $1.68(-1)$ & $2.12(-1)$ & $2.57(-2)$ \\
\hline 126 & & & $2.09(-1)$ & $2.62(-1)$ & $3.18(-2)$ \\
\hline 116 & & & $2.62(-1)$ & $3.28(-1)$ & $4.09(-2)$ \\
\hline 106 & & & $3.26(-1)$ & $4.06(-1)$ & $4.89(-2)$ \\
\hline 96 & & & $4.09(-1)$ & $5.10(-1)$ & $6.16(-2)$ \\
\hline 86 & & & $5.10(-1)$ & $6.48(-1)$ & $7.82(-2)$ \\
\hline 76 & & & $6.37(-1)$ & $7.84(-1)$ & $9.39(-2)$ \\
\hline 66 & & & $6.96(-1)$ & $8.42(-1)$ & $1.04(-1)$ \\
\hline 56 & & & $7.91(-1)$ & $9.57(-1)$ & $1.14(-1)$ \\
\hline 46 & & & $8.79(-1)$ & $1.06(0)$ & $1.27(-1)$ \\
\hline 36 & & & $9.40(-1)$ & $1.13(0)$ & $1.36(-1)$ \\
\hline 26 & & & $9.74(-1)$ & $1.16(0)$ & $1.40(-1)$ \\
\hline 16 & & & $9.83(-1)$ & $1.17(0)$ & $1.41(-1)$ \\
\hline 6 & & & $9.70(-1)$ & $1.15(0)$ & $1.41(-1)$ \\
\hline 0 & & & $9.54(-1)$ & $1.13(0)$ & $1.37(-1)$ \\
\hline 0 & $3.21(-1)^{b}$ & $1.24(-1)$ & $9.41(-1)$ & $1.15(0)$ & $1.39(-1)$ \\
\hline 10 & & & $9.01(-1)$ & $1.11(0)$ & $1.31(-1)$ \\
\hline 20 & $2.91(-1)$ & $1.10(-1)$ & $8.68(-1)$ & $1.02(0)$ & $1.23(-1)$ \\
\hline 30 & & & $7.71(-1)$ & $9.41(-1)$ & $1.12(-1)$ \\
\hline 40 & $2.47(-1)$ & $9.02(-2)$ & $6.96(-1)$ & $8.41(-1)$ & $1.01(-1)$ \\
\hline 50 & & & $5.99(-1)$ & $7.22(-1)$ & $8.87(-2)$ \\
\hline 60 & & & $5.08(-1)$ & $6.17(-1)$ & $7.47(-2)$ \\
\hline 70 & & & $4.34(-1)$ & $5.15(-1)$ & $6.34(-2)$ \\
\hline 72 & $1.63(-1)$ & $5.44(-2)$ & & & \\
\hline 80 & & & $3.66(-1)$ & $4.46(-1)$ & $5.37(-2)$ \\
\hline 81 & $1.48(-1)$ & $4.62(-2)$ & & & \\
\hline 90 & & & $3.03(-1)$ & $3.54(-1)$ & $4.43(-2)$ \\
\hline 100 & & & $2.37(-1)$ & $2.92(-1)$ & $3.56(-2)$ \\
\hline 101 & $1.13(-1)$ & $3.09(-2)$ & & & \\
\hline 110 & & & $1.94(-1)$ & $2.39(-1)$ & $2.92(-2)$ \\
\hline 120 & & & $1.55(-1)$ & $1.92(-1)$ & $2.39(-2)$ \\
\hline 130 & & & $1.23(-1)$ & $1.53(-1)$ & $1.90(-2)$ \\
\hline 135 & $7.92(-2)$ & $1.49(-2)$ & & & \\
\hline 140 & & & $1.00(-1)$ & $1.20(-1)$ & $1.48(-2)$ \\
\hline $145 \mathrm{~S}$ & & & & & $1.28(-2)$ \\
\hline
\end{tabular}

${ }^{a}$ See experimental program plan in Appendix A for description of configurations.

${ }^{b}$ Read: $3.21 \times 10^{-1}$. 

APPENDIX C

FIGURES 

年

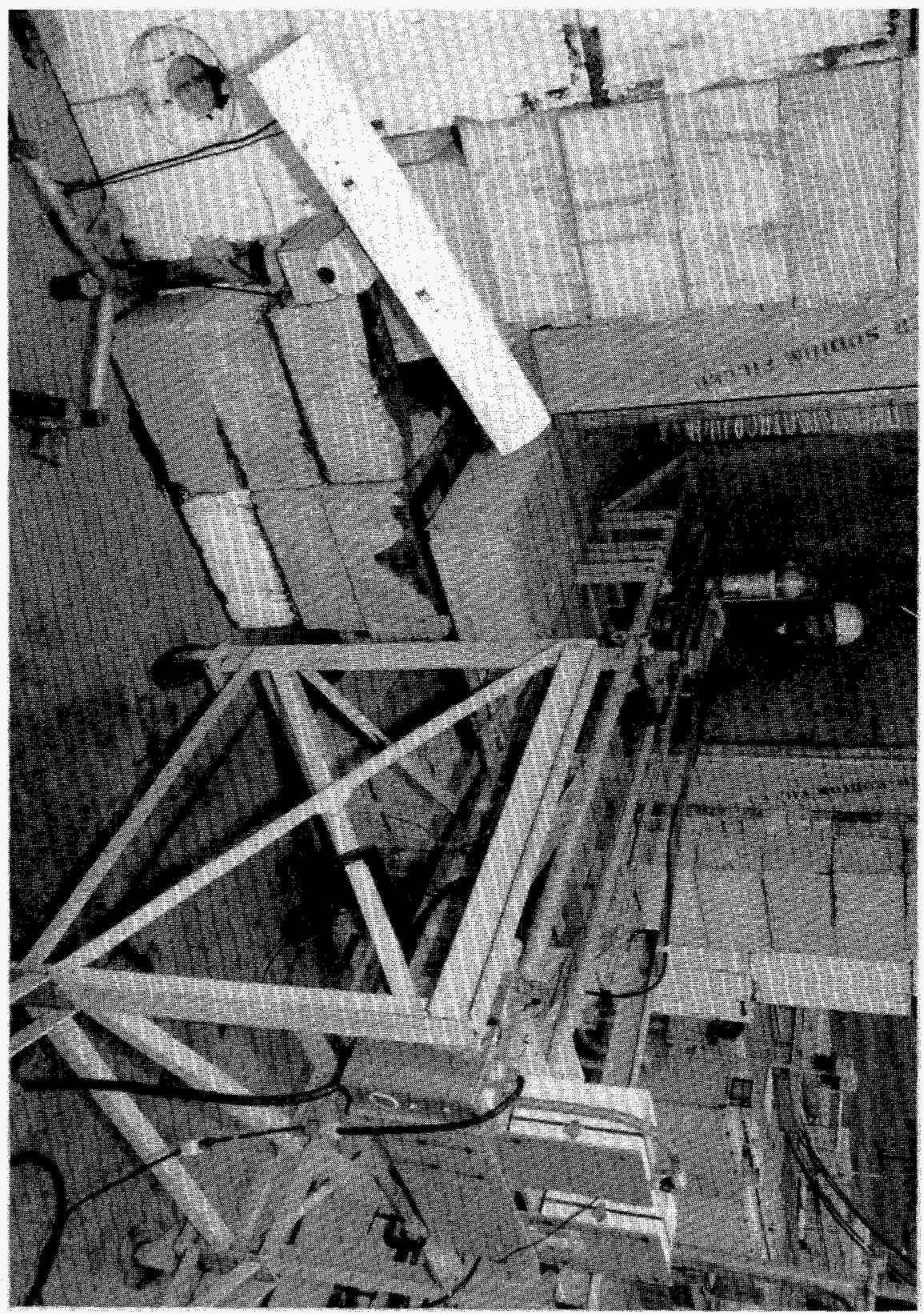




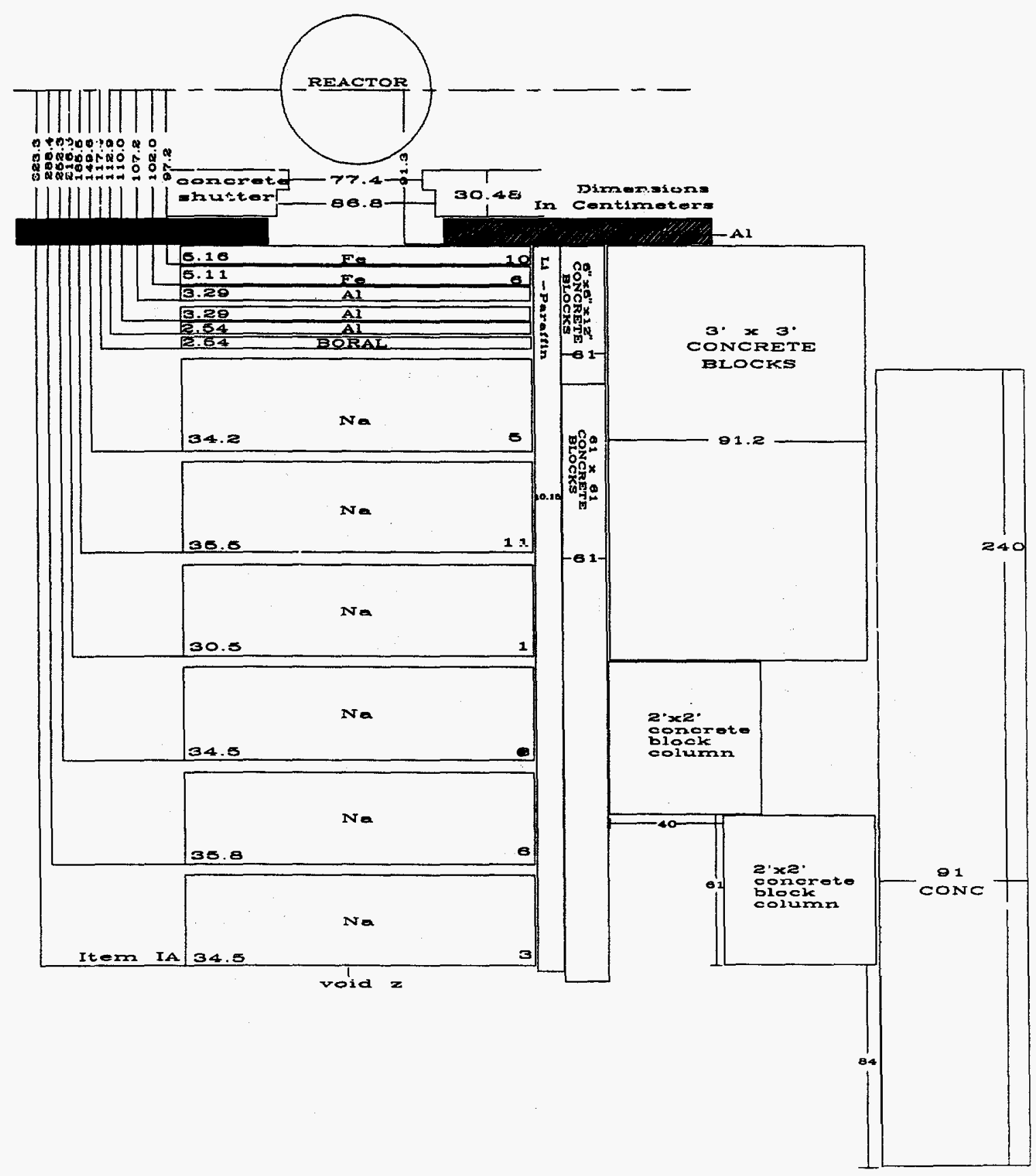

Figure 2. Schematic of SM-2 (iron + aluminum + boral + sodium). Item IA 

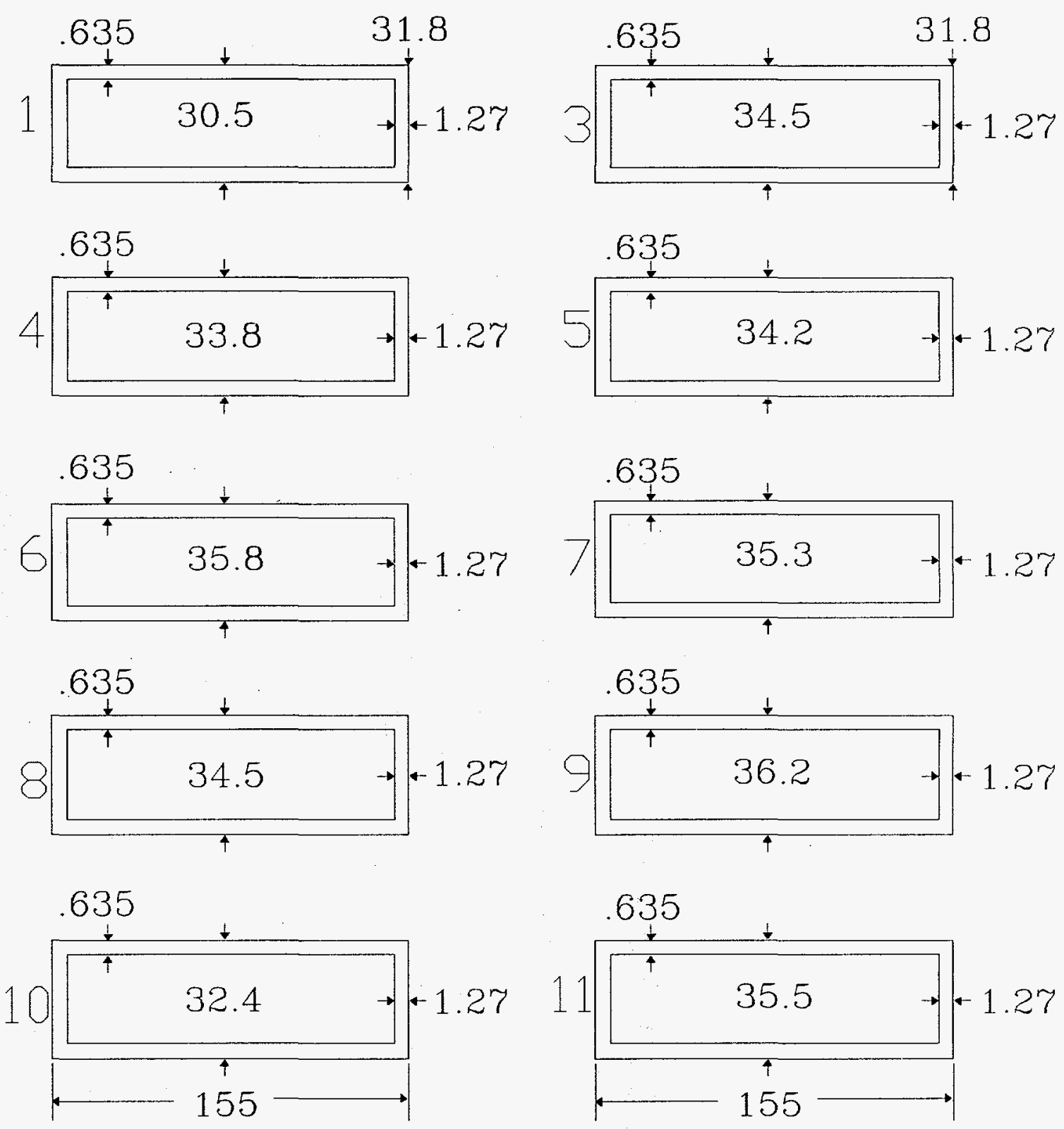

Figure 3. Schematic of aluminum containers filled with sodium. 


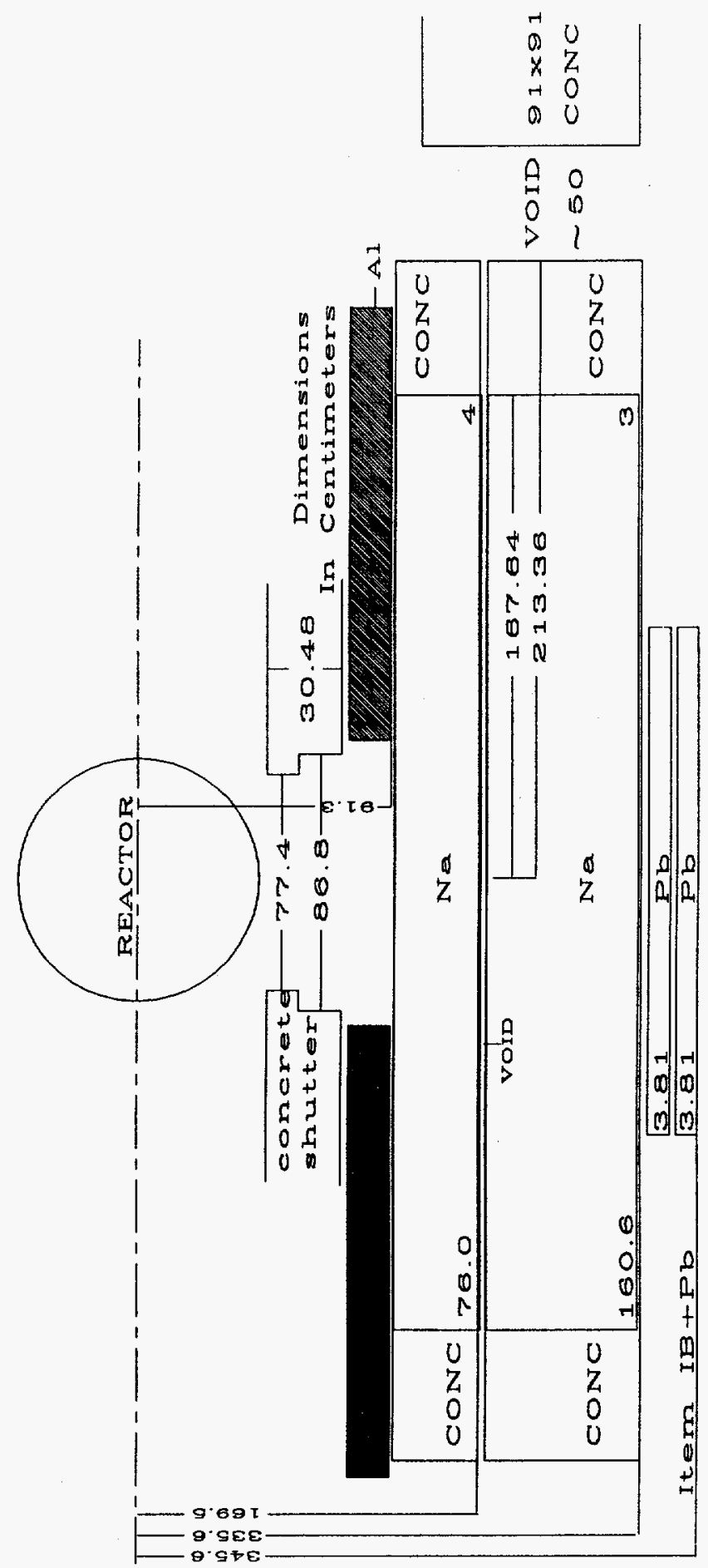

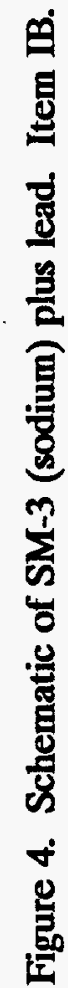




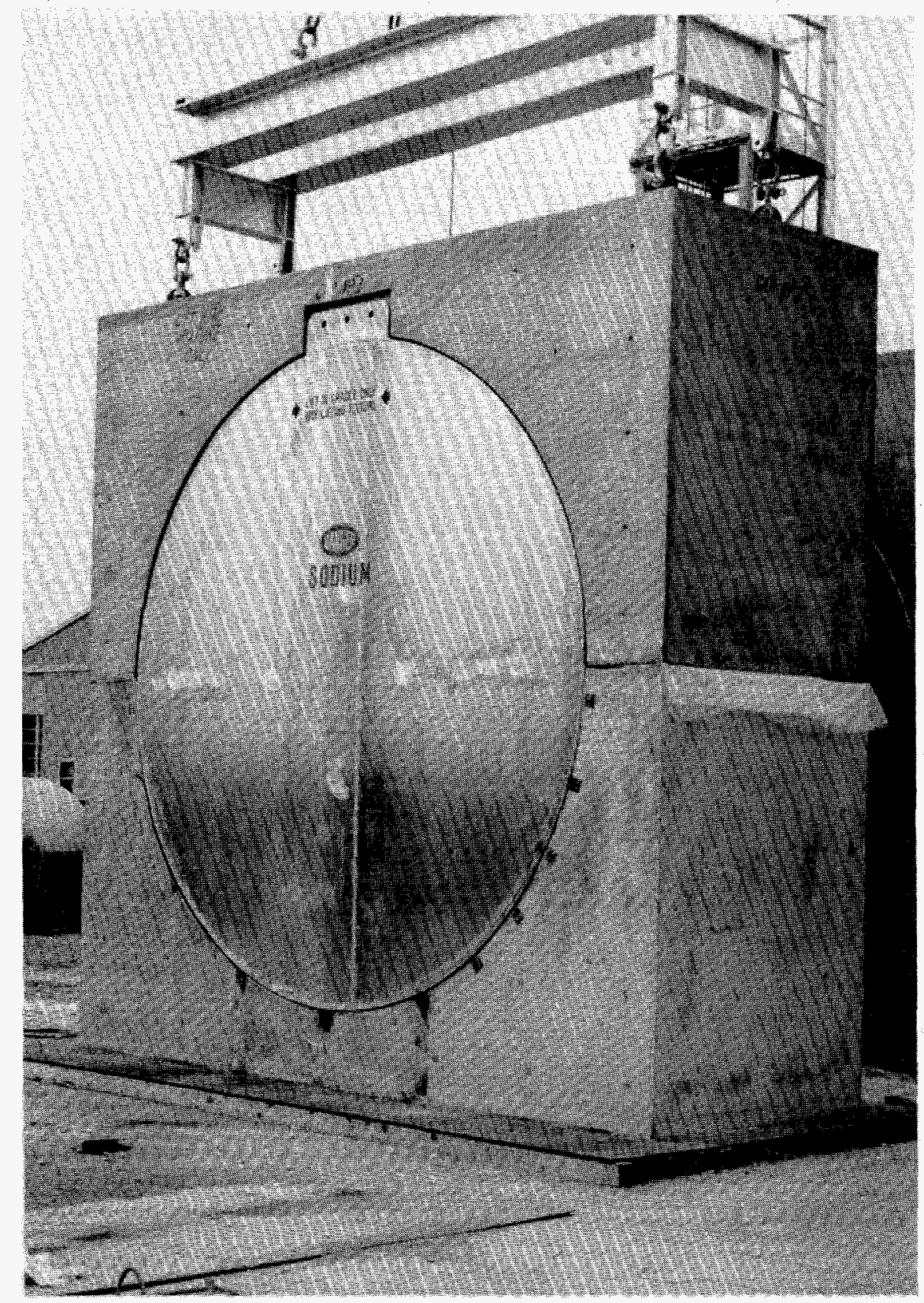

Figure 5. A photograph of a typical sodium-filled, aluminum-walled cylindrical vessel used in SM-3. 


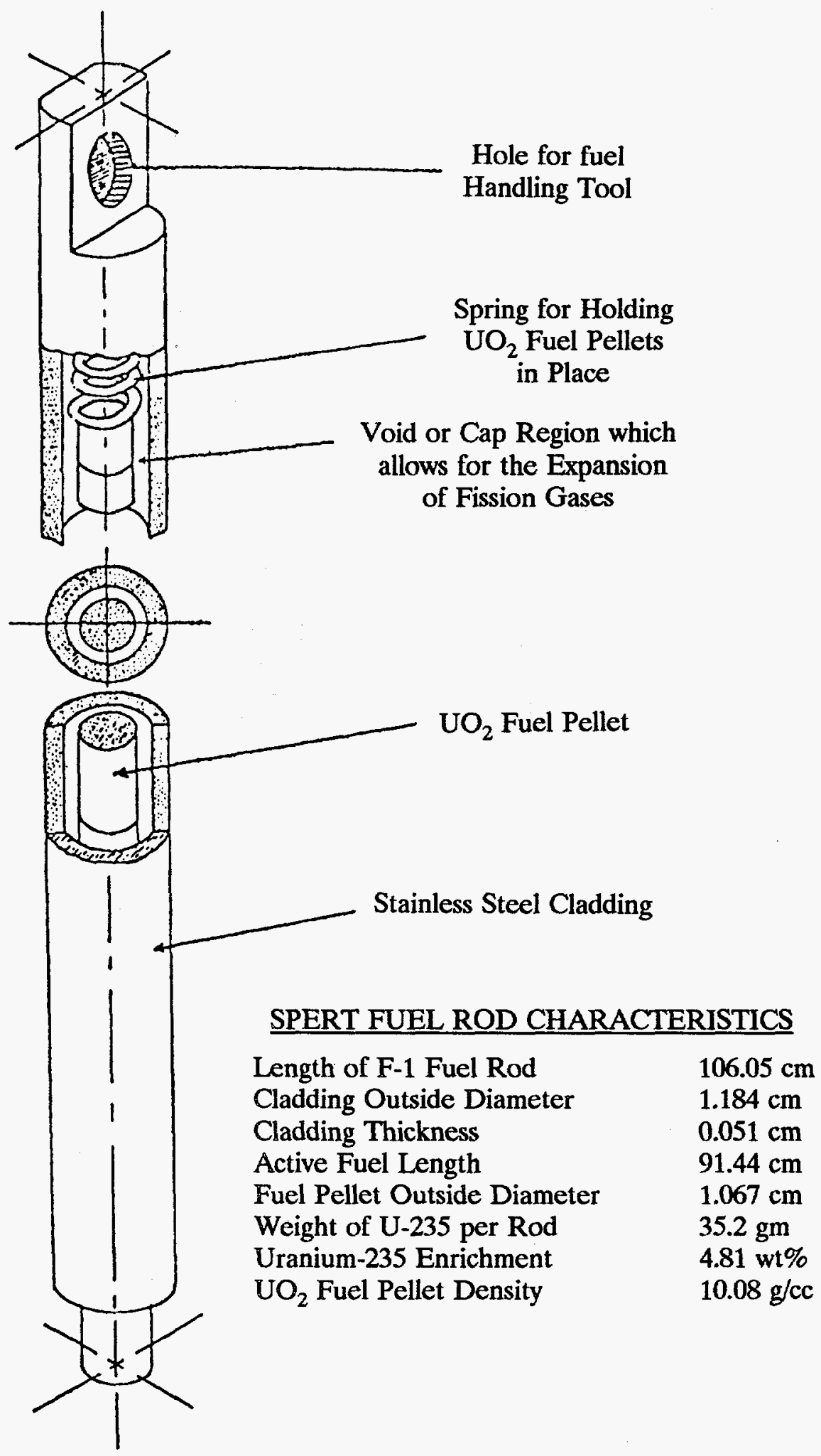

Figure 6. Isometric of the SPERT fuel rod containing Uranium-Dioxide fuel pellets. 


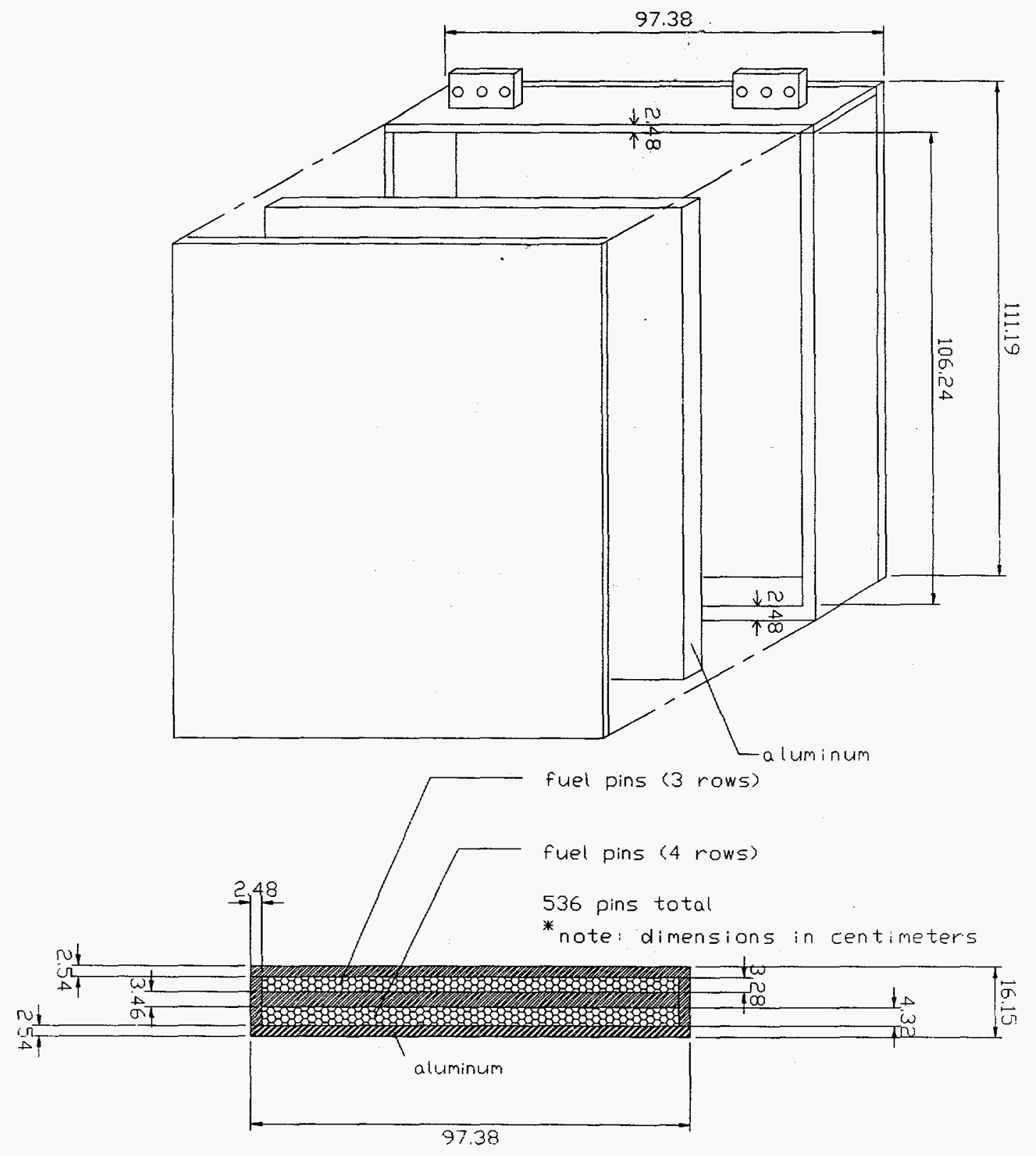

Figure 7. Schematic of Homogeneous IVFS Mockup (Slab \#3). 


\section{$B_{4}$ C CONTAINERS}
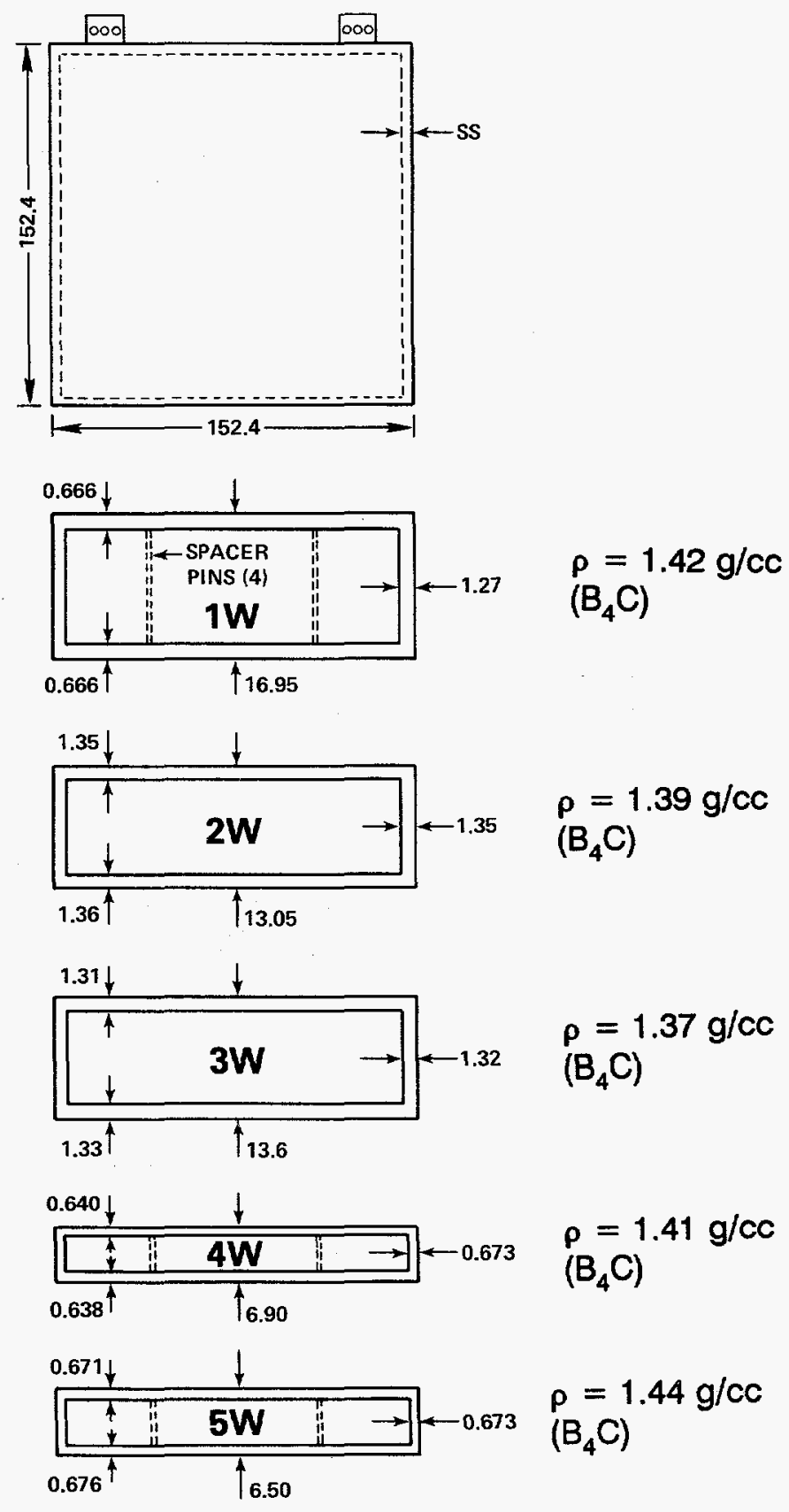

(ALL DIMENSIONS ARE IN CENTIMETERS)

Figure 8. Schematic of stainless steel containers used for boron-carbide-filled shield slabs. 

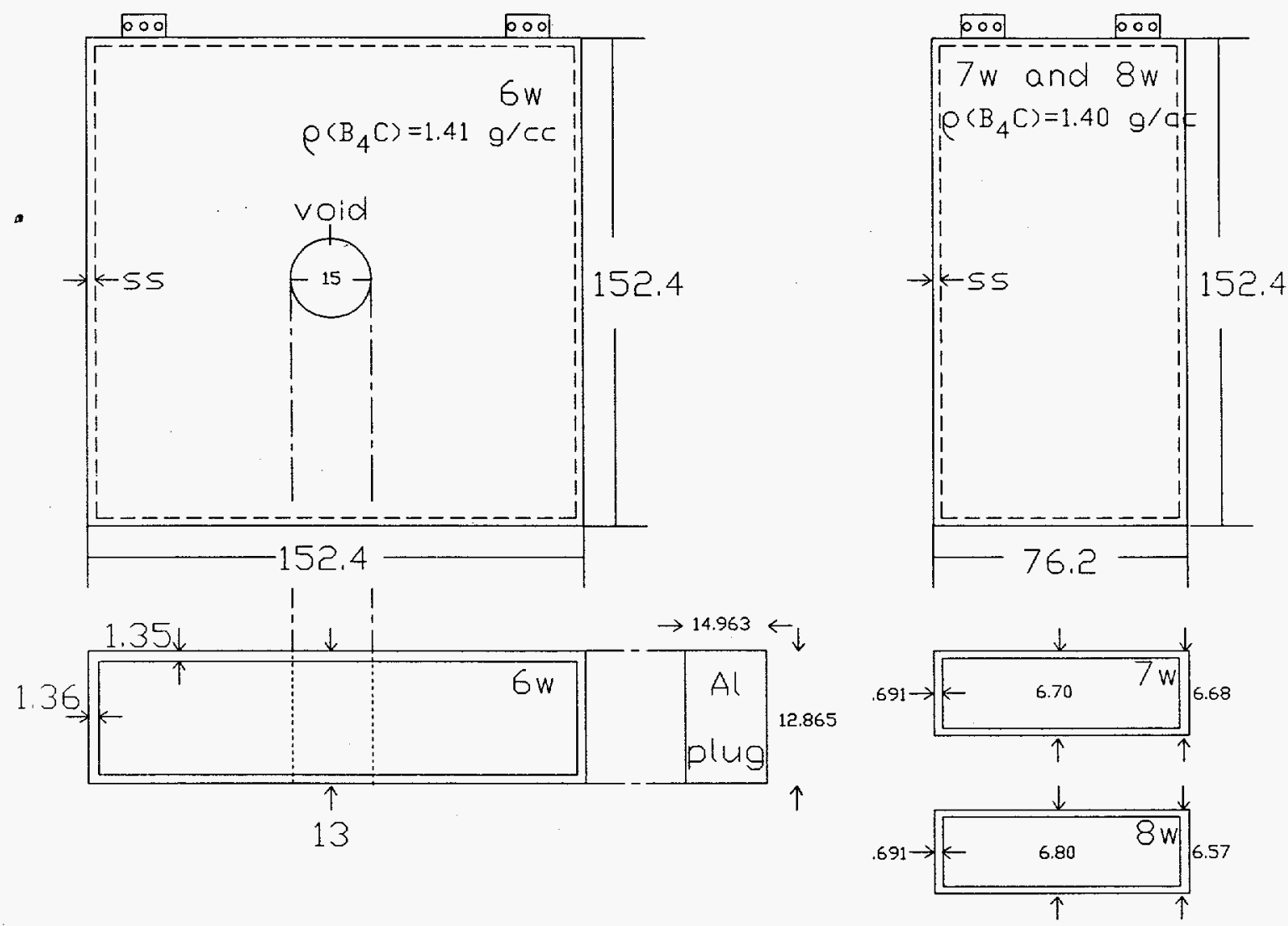
slabs.

Figure 9. Schematic of stainless steel containers used for boron-carbide-filled shield 

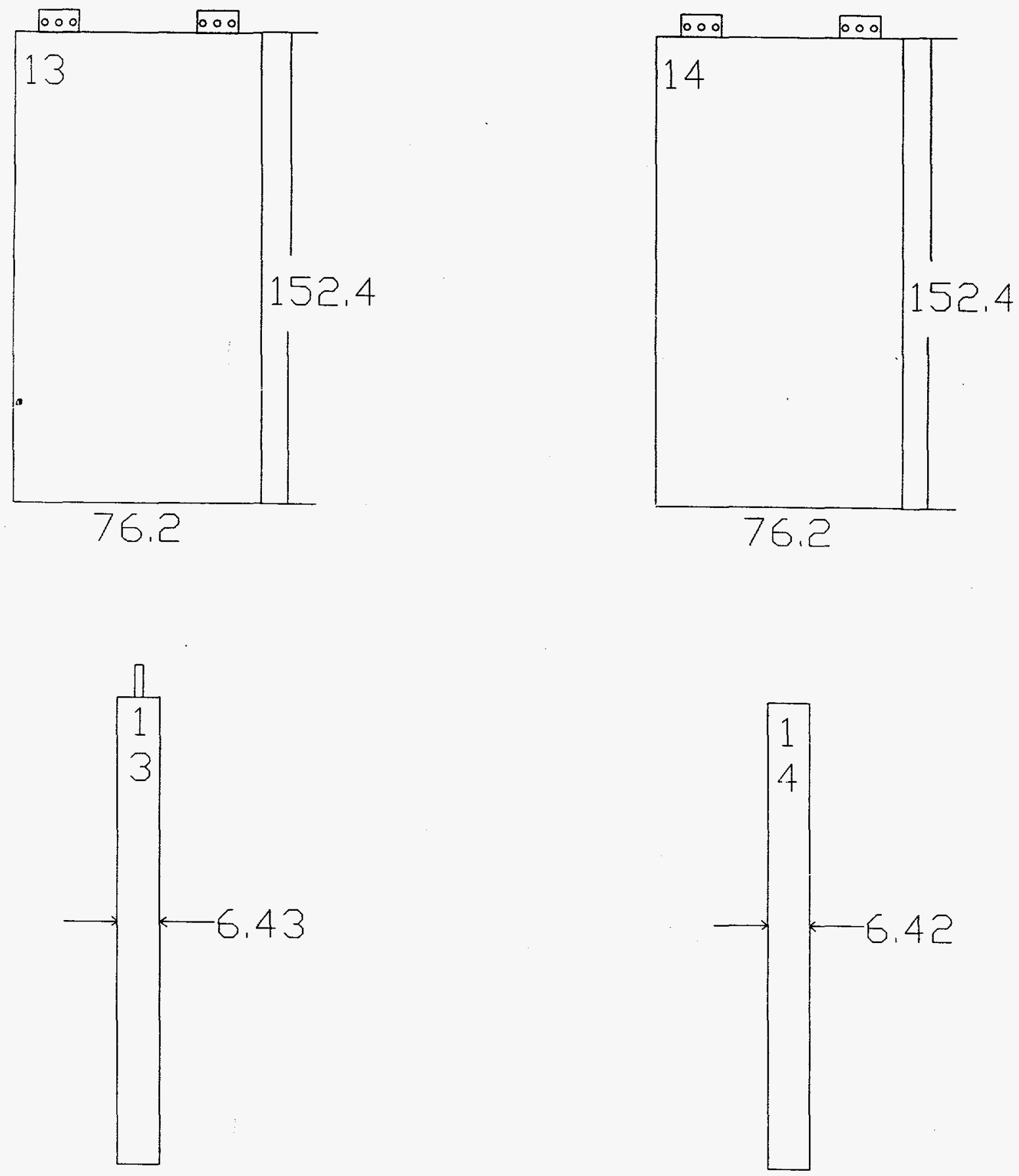

Figure 10. Schematic of aluminum slabs (dimensions in $\mathbf{c m}$ ). 
Dimensions in units of centimeters

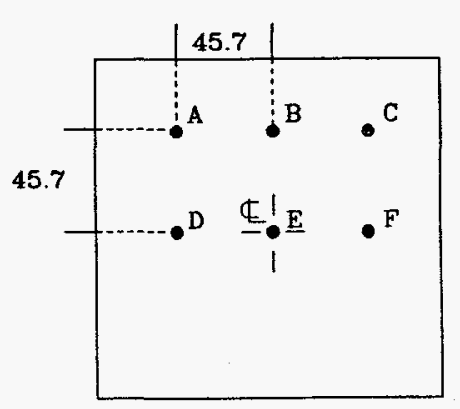

Fo:1 Locations

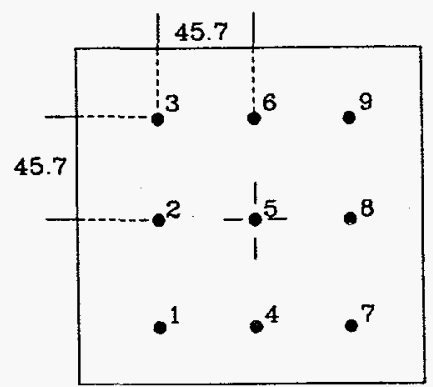

Foil Locations

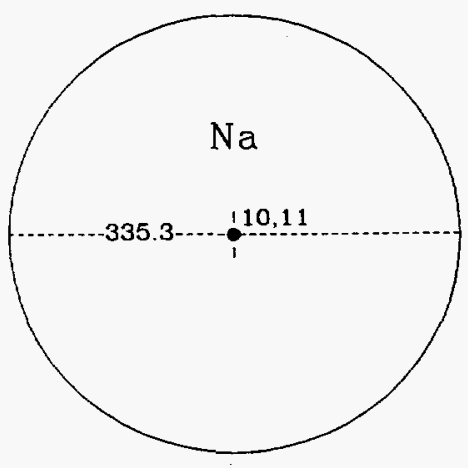

Foil Locations

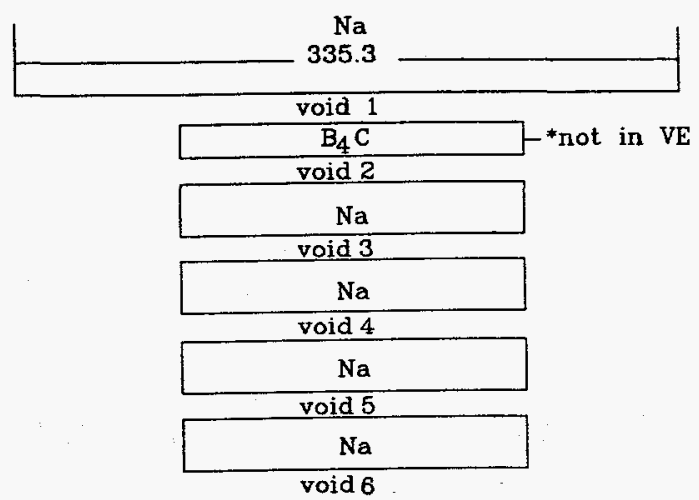

Items VE, VIE, VIIF, VIIIF, IXE, XE

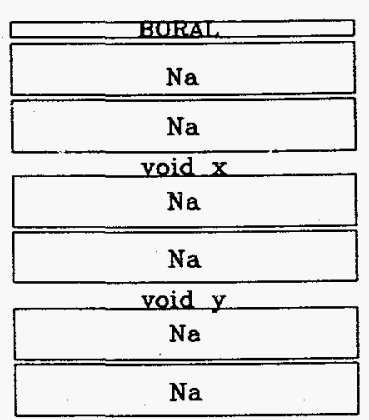

Item IAA

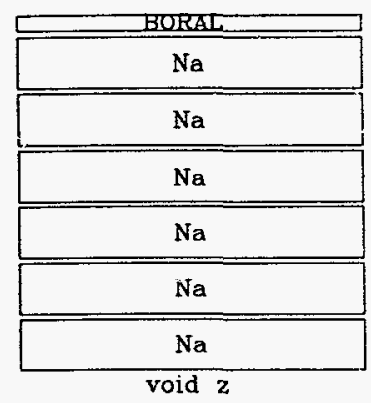

Item IA

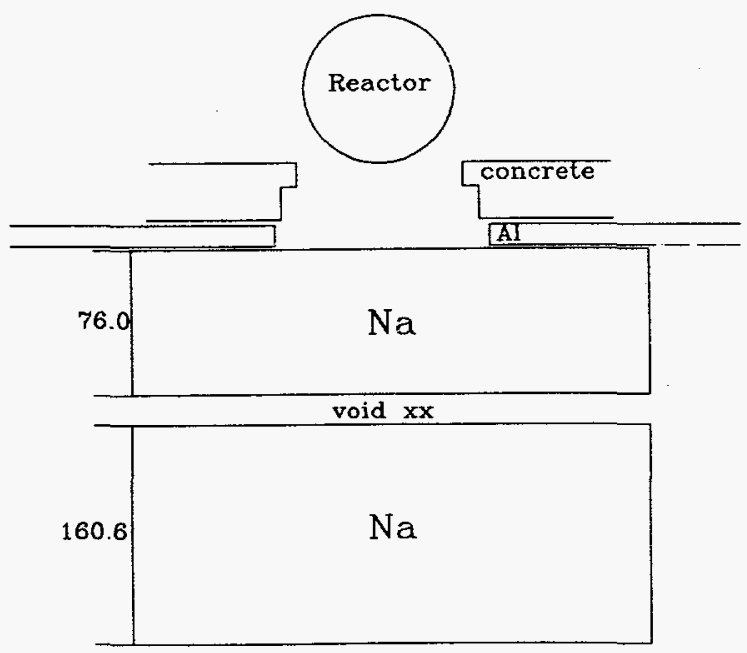

Item IB

Figure 11. Schematic of sodium foil locations within mockups. Items IA, IAA, IB, VE, VIE, VIIF, VIIIF, IXE, XE 


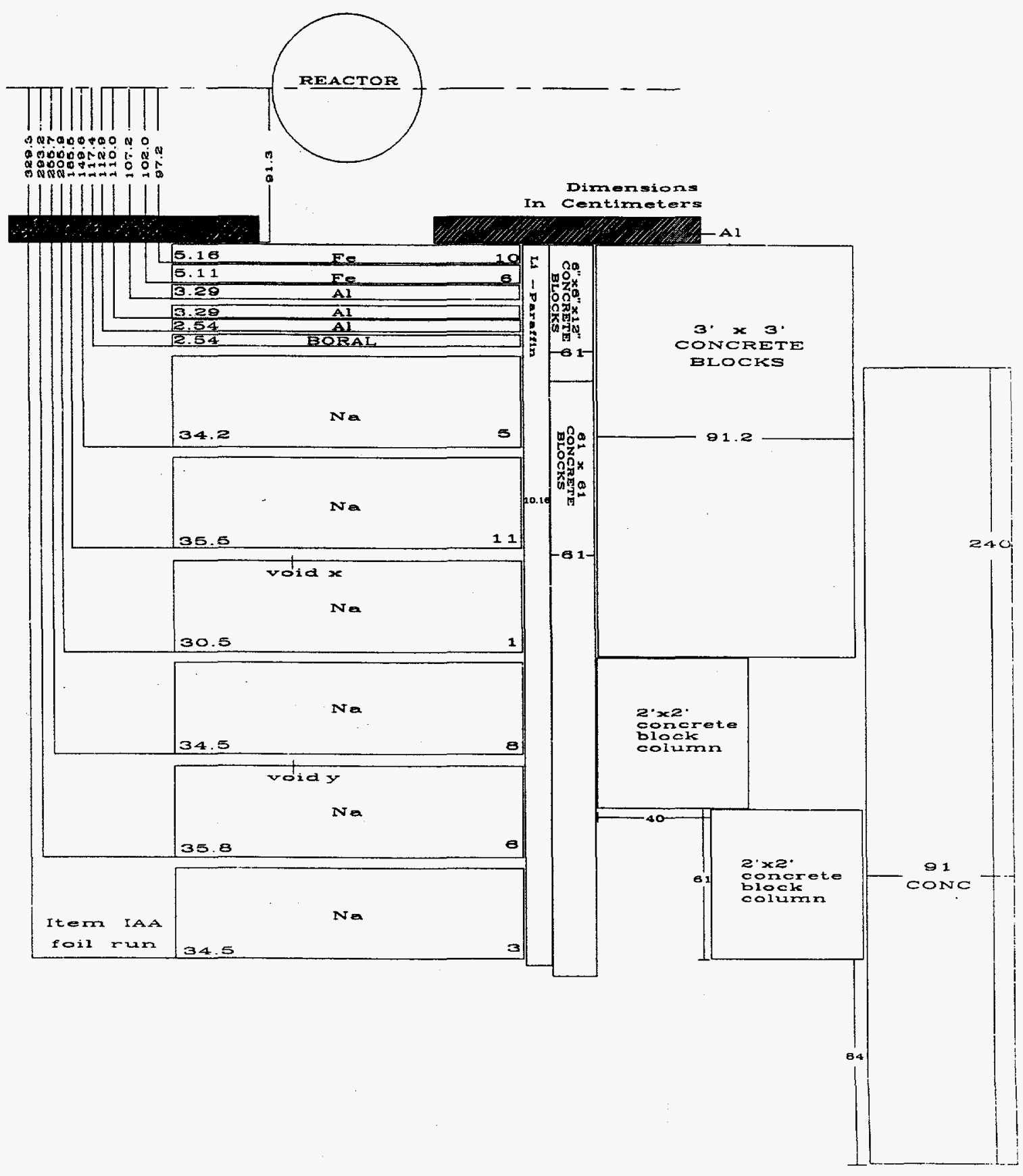

Figure 12. Schematic of SM-2 (iron + aluminum + boral + sodium) for foil run. Item IAA. 
อัด

岳

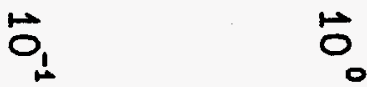

(Neutrons $\mathrm{cm}^{-2} \mathrm{MeV}^{-1} \mathrm{~kW}^{-1} \mathrm{~s}^{-1}$ )

点

은

承

$0+$

0

$\overrightarrow{0}$

$\stackrel{0}{\circ}$

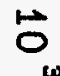

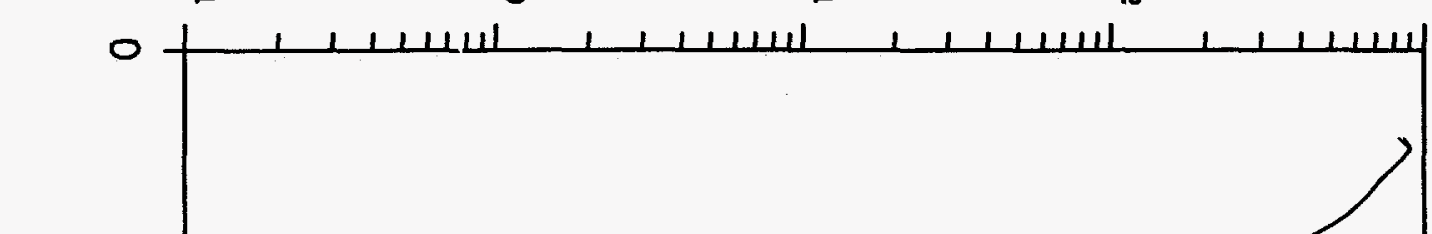

V

3

:

ह

N

令

8

实

훙

$\overline{8}$

产

ฮ

흐

$\overparen{\Xi}$

స్ర

$z$
0
$\frac{1}{7}$
o
m
$\frac{0}{0}$
$\frac{0}{0}$
$\frac{1}{3}$
$\frac{1}{5}$

$\omega$

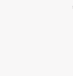




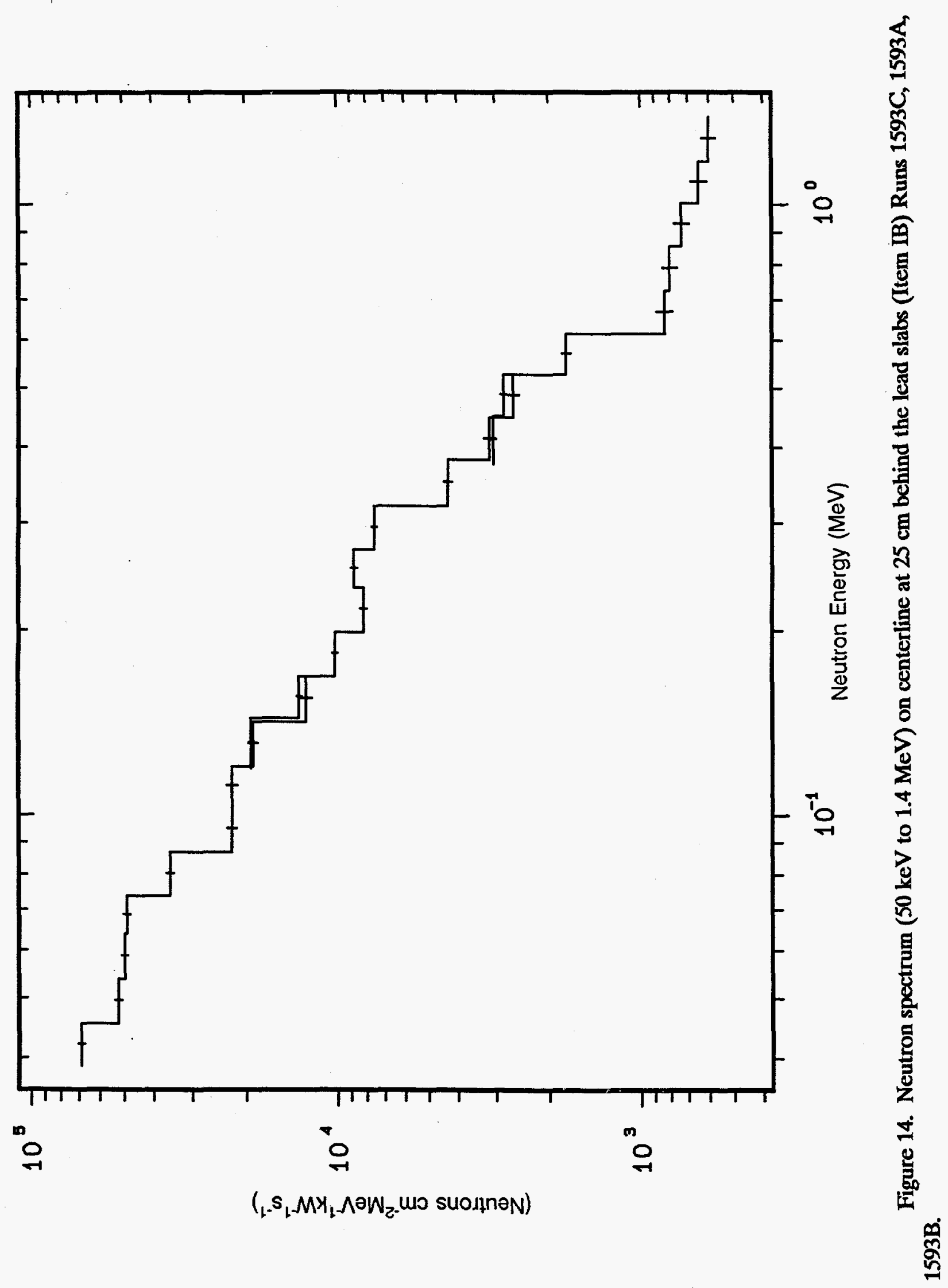




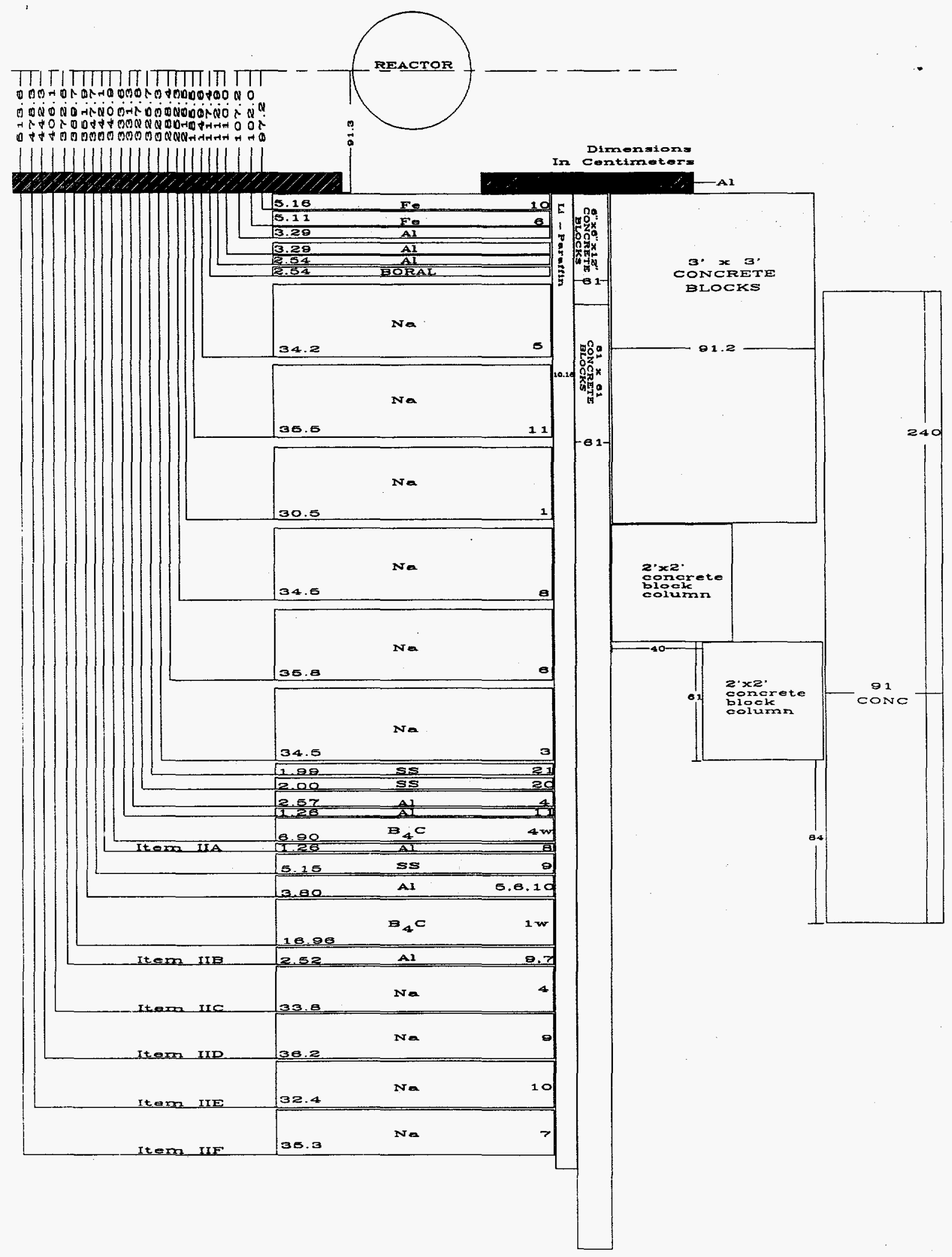

Figure 15. Schematic of SM-2 plus shield configurations for Item II. 


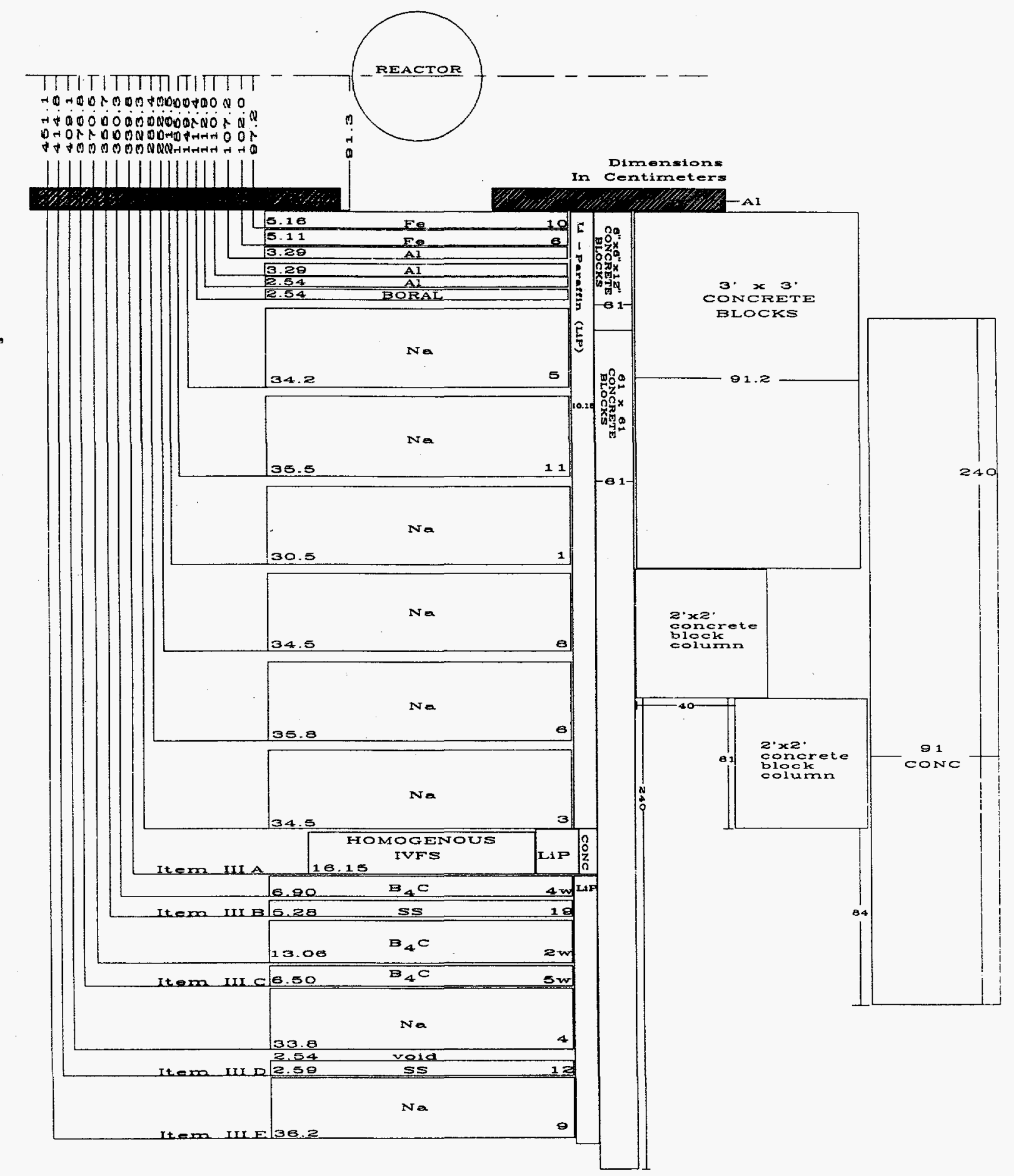

Figure 16. Schematic of SM-2 plus shield configurations for Item III. 


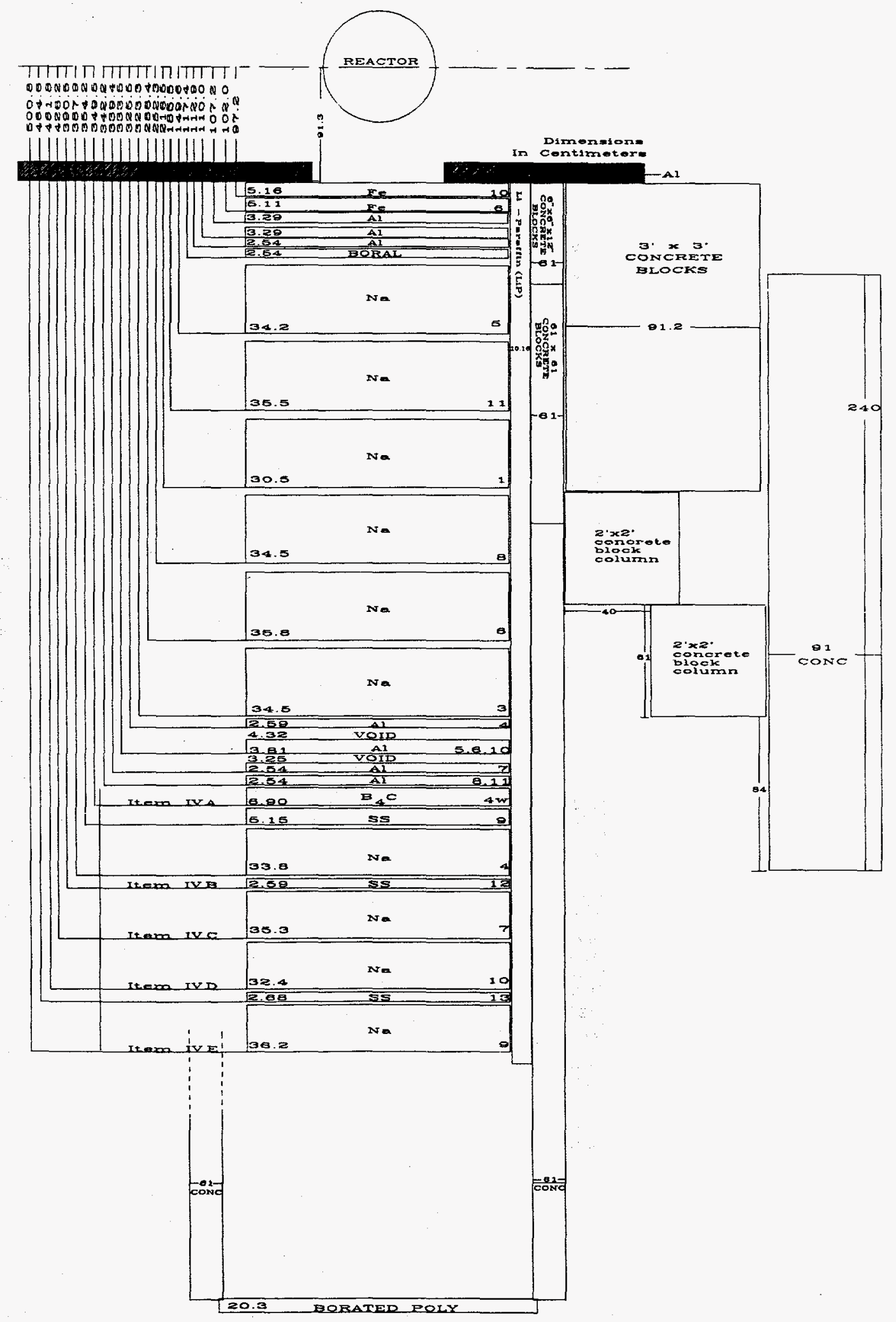

Figure 17. Schematic of SM-2 plus shield configurations for Item IV. 


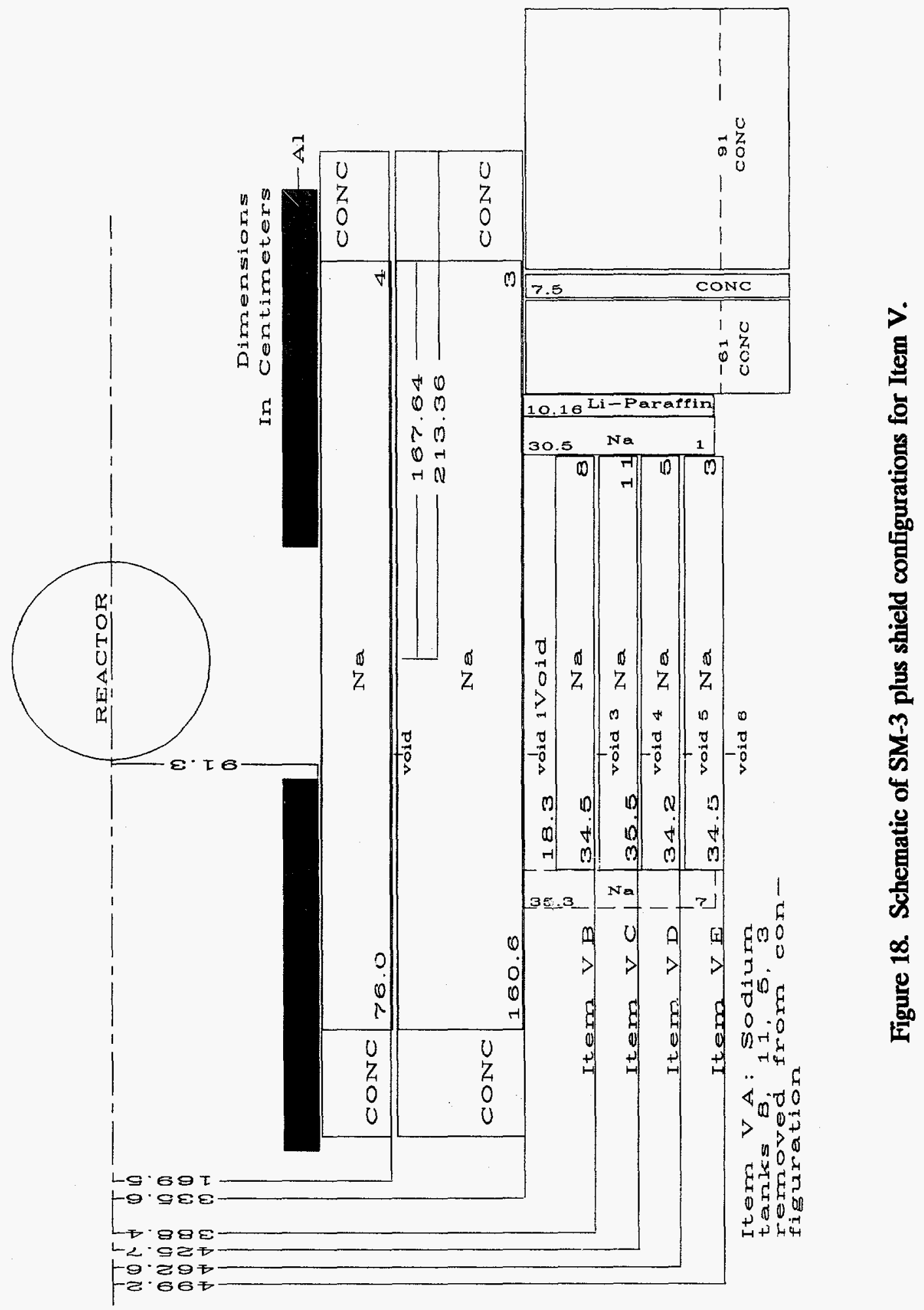




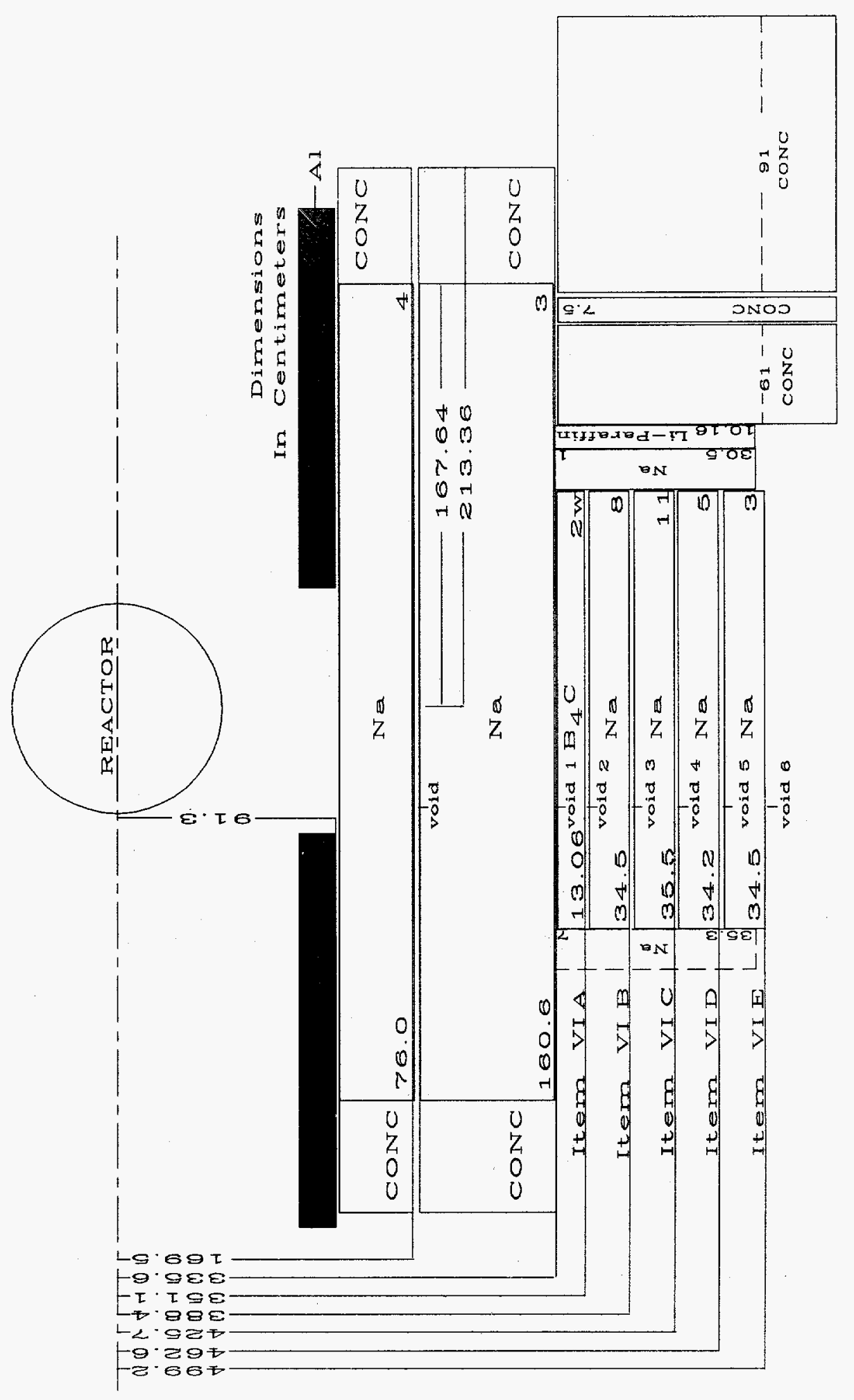

它 


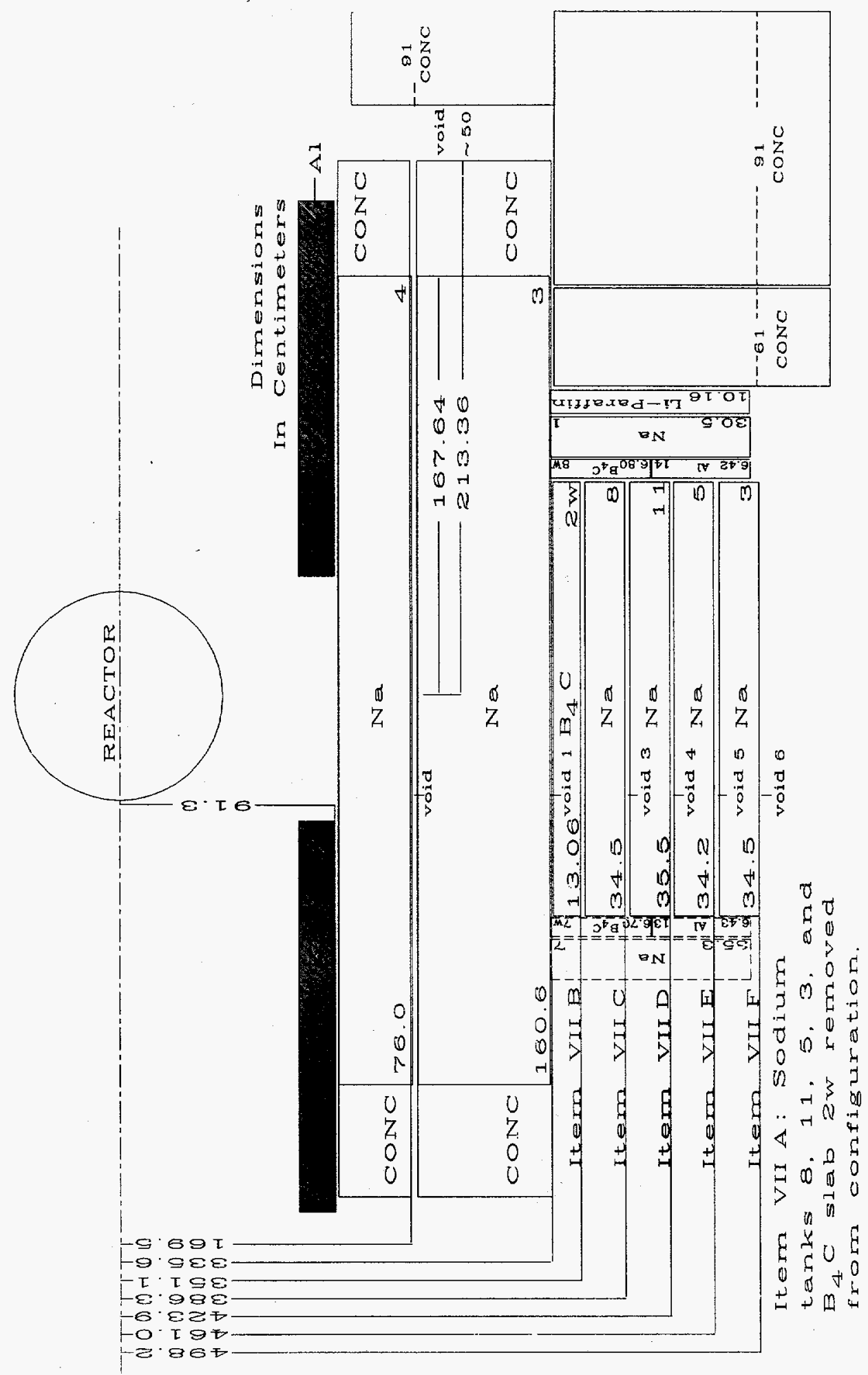

焉 


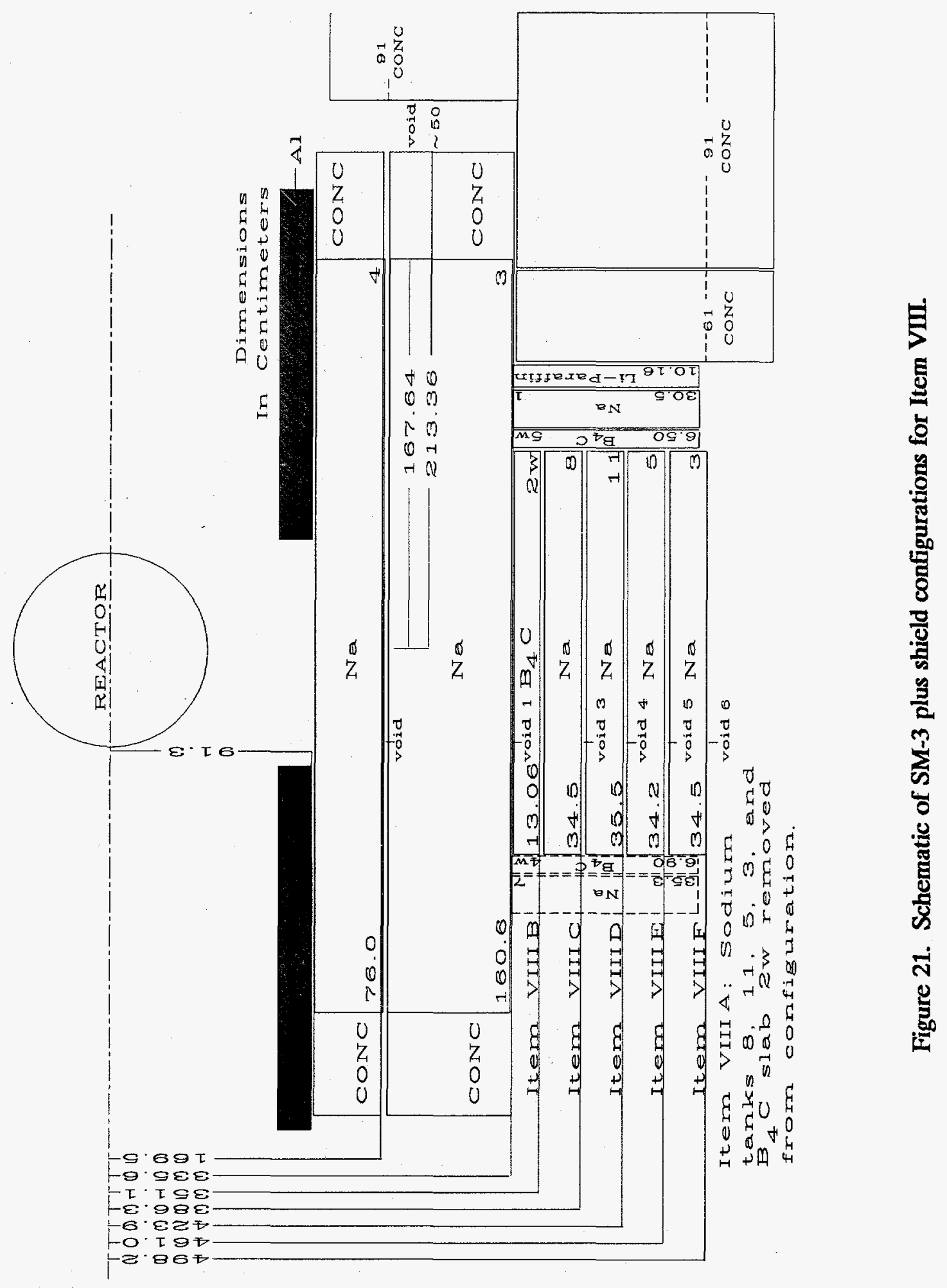




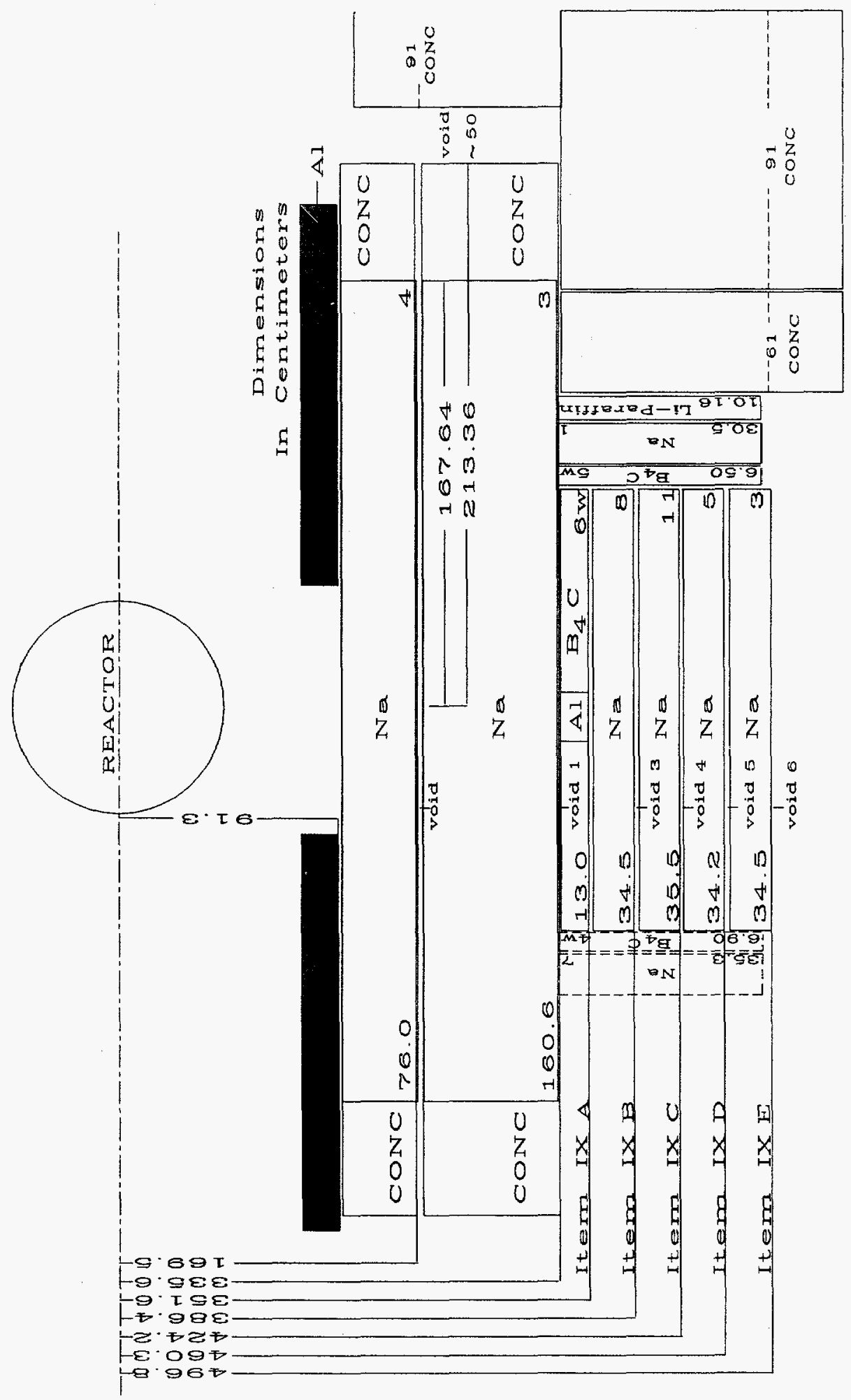

है 


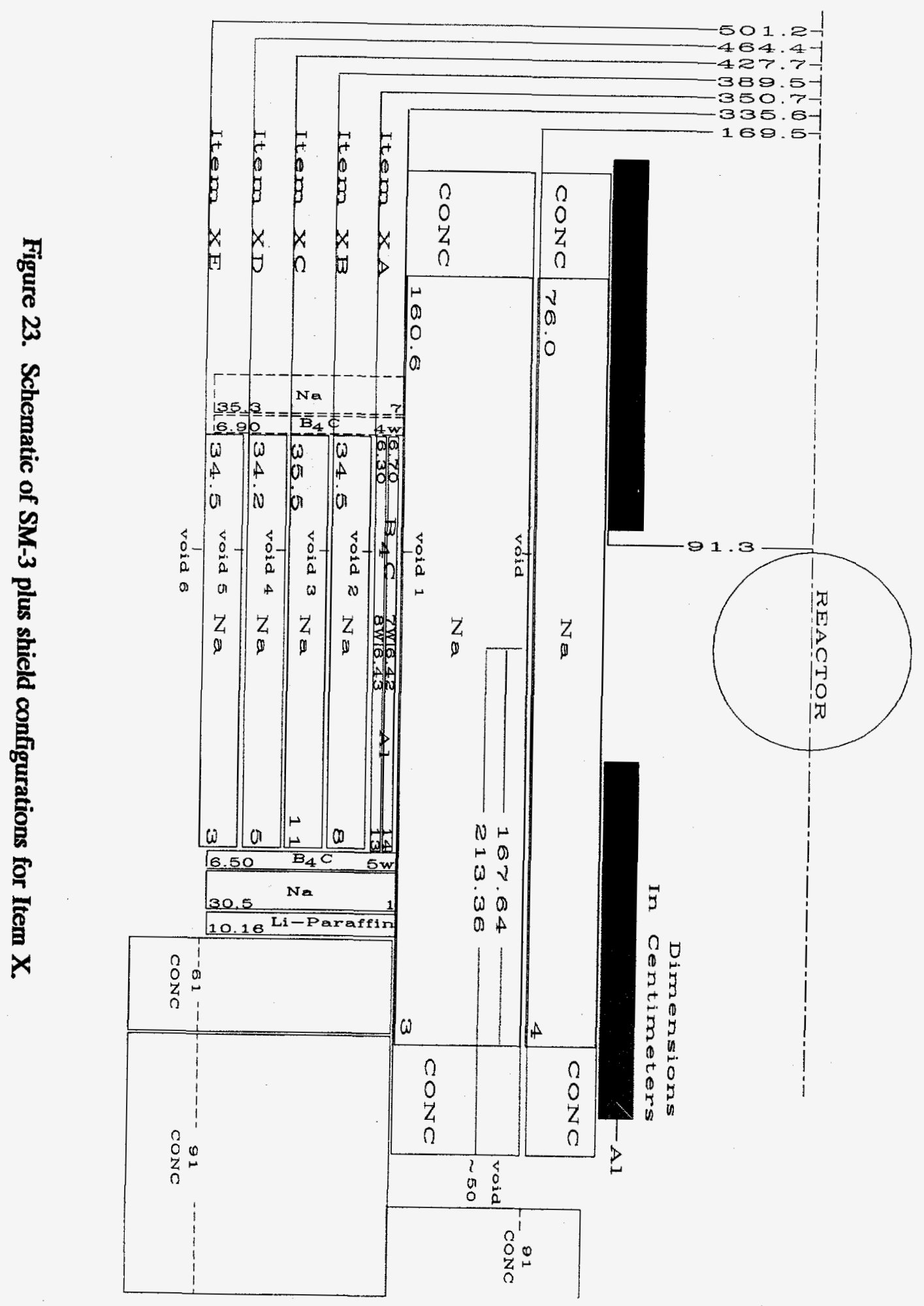




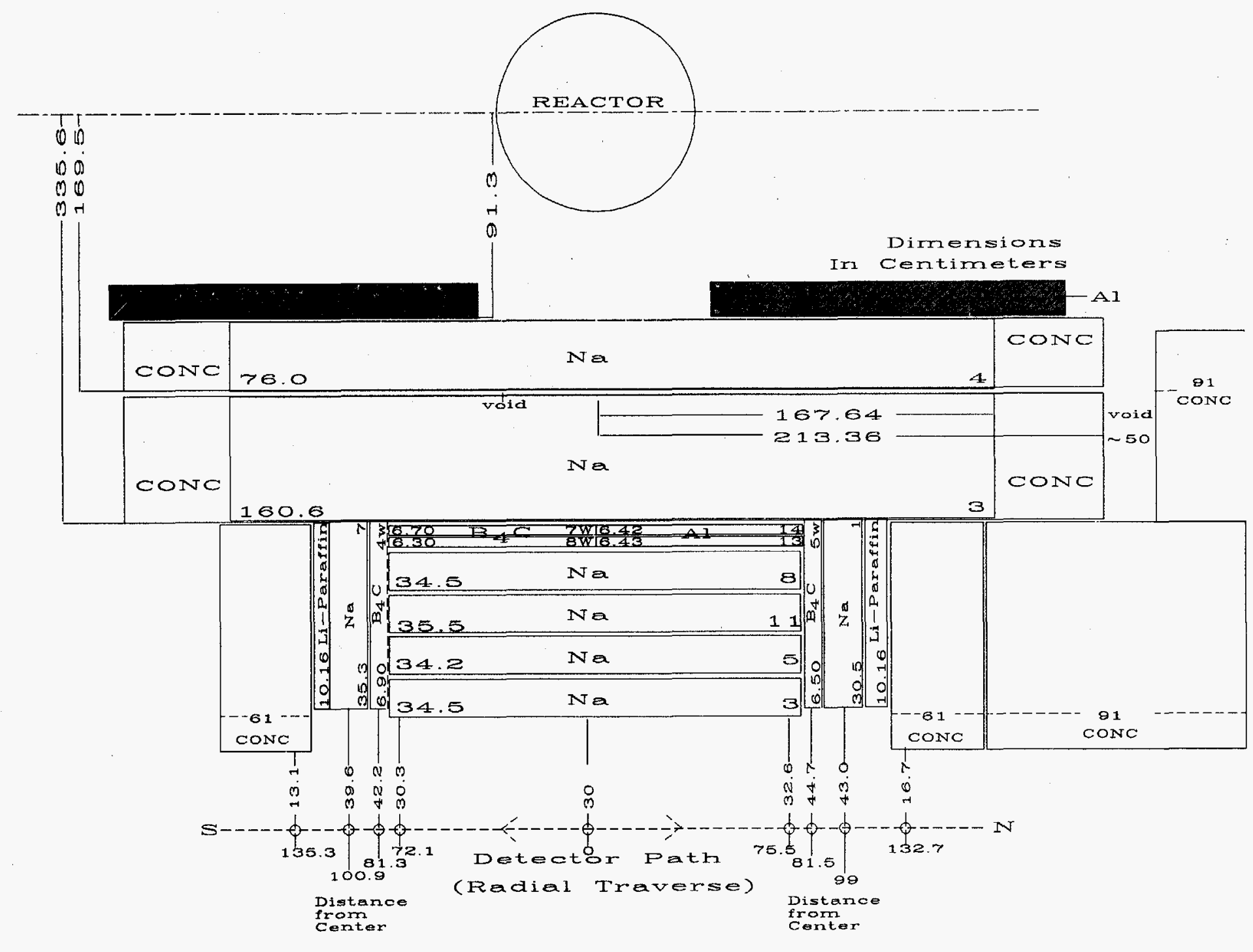

Figure 24. Schematic of SM-3 plus shield configuration for radial traverses beyond mockup in Item X. 
ORNL/TM-12064

Distribution Category

DISTRIBUTION

UC 534 .

1. B. R. Appleton

2. J. A. Bucholz

3. L. B. Holland

4. F. J. Homan

5. J. L. Hull

6. H. T. Hunter

7-16. D. T. Ingersoll

17-18. F. J. Muckenthaler

19. J. V. Pace, III

20. A. Shono

21. C. O. Slater
22. R. R. Spencer

23. R. C. Ward

24. J. D. White

25. A. Zucker

26. Central Research Library

27-31. EPMD Reports Office

32. ORNL Y-12 Technical Library Document Reference Section

33-35. Laboratory Records

36. ORNL Patent Office

\section{EXTERNAL DISTRIBUTION}

37. Office of Assistant Manager for Energy Research and Development, DOE-OR, P.O. Box 2008, Oak Ridge, TN 37831-6269.

38. L. F. Blankner, Energy Research and Development, DOE-OR, P.O. Box 2008, Oak Ridge, TN 37831-6269.

39. Prof. Roger W. Brockett, Harvard University, Pierce Hall, 29 Oxford Street, Cambridge, Massachusetts 02138.

40. L. L. Carter, Westinghouse-Hanford Company, 400 Area Trailer 1, P.O. Box 1970, Richland WA 99352.

41. R. K. Disney, Westinghouse Electric Company, P.O. Box 158, Madison, PA 15663.

42. Prof. John J. Dorning, Department of Nuclear Engineering and Engineering Physics Reactor Facility, University of Virginia, Charlottesville, VA 22903.

43. P. B. Hemmig, Safety and Physics Branch, Office of Technology Support Programs, DOE-Washington, Washington, DC 20585.

44. Dr. James E. Leiss, Route 2, Box 142C, Broadway, VA 22815.

45. Prof. Neville Moray, Department of Mechanical and Industrial Engineering, 1206 West Green Street, Urbana, IL 61801. 
46. Prof. Mary F. Wheeler, Department of Mathematical Sciences, Rice University, P.O. Box 1892, Houston, TX 77251.

47. K. Takahashi, Power Reactor and Nuclear Fuel Development Corporation, Sankaido Building, 9-13, 1-Chome, Akasaka Minato-Ku, Tokyo 107, Japan.

48. M. Tsutsumi, Power Reactor and Nuclear Fuel Development CorporationWashington, Suite 715, 2600 Virginia Avenue NW, Washington, DC 20037.

49. K. Chatani, Power Reactor and Nuclear Fuel Development Corporation, 4002 Narita-Cho, O-Arai-Machi, Ibaraki-Ken, 311-13, Japan.

50-122. Given distribution as shown in DOE/OSTI-4500-R75, LMFBR-Physics: 